\title{
Ground-based aerosol climatology of China: aerosol optical depths from the China Aerosol Remote Sensing Network (CARSNET) 2002-2013
}

H. Che ${ }^{1,2}$, X.-Y. Zhang ${ }^{1,2}$, X. Xia ${ }^{3,4}$, P. Goloub ${ }^{5}$, B. Holben ${ }^{6}$, H. Zhao ${ }^{7}$, Y. Wang ${ }^{1}$, X.-C. Zhang ${ }^{8}$, H. Wang ${ }^{1}$, L. Blarel ${ }^{5}$, B. Damiri ${ }^{9}$, R. Zhang ${ }^{10}$, X. Deng ${ }^{11}$, Y. Ma ${ }^{7}$, T. Wang ${ }^{12}$, F. Geng ${ }^{13}$, B. Qi ${ }^{14}$, J. Zhu ${ }^{3}$, J. Yu ${ }^{15}$, Q. Chen ${ }^{15}$, and G. Shi ${ }^{16}$

${ }^{1}$ Key Laboratory of Atmospheric Chemistry (LAC), Chinese Academy of Meteorological Sciences (CAMS), CMA, Beijing, 100081, China

${ }^{2}$ Jiangsu Collaborative Innovation Center of Climate Change, Nanjing, 210093, China

${ }^{3}$ Laboratory for Middle Atmosphere and Global Environment Observation (LAGEO), Institute of Atmospheric Physics, Chinese Academy of Sciences, Beijing, 100029, China

${ }^{4}$ Collaborative Innovation Center on Forecast and Evaluation of Meteorological Disasters, Nanjing University of Information Science \& Technology, Nanjing, 210044, China

${ }^{5}$ Laboratoire d'Optique Amosphérique, Université des Sciences et Technologies de Lille, 59655, Villeneuve d'Ascq, France

${ }^{6}$ Biospheric Sciences Branch, Code 923, NASA/Goddard Space Flight Center, Greenbelt, MD, USA

${ }^{7}$ Institute of Atmospheric Environment, China Meteorological Administration, Shenyang 110016, China

${ }^{8}$ Meteorological Observation Center, CMA, Beijing, 100081, China

${ }^{9}$ Cimel Électronique, Paris, 75011, France

${ }^{10}$ Key Laboratory of Regional Climate-Environment for Temperate East Asia (RCE-TEA), Institute of Atmospheric Physics, Chinese Academy of Sciences, Beijing, 100029, China

${ }^{11}$ Institute of Tropical and Marine Meteorology/Guangdong Provincial Key Laboratory of Regional Numerical Weather

Prediction, CMA, Guangzhou, 510080, China

${ }^{12}$ School of Atmospheric Sciences, Nanjing University, Hankou Rd. 22, Nanjing, 210093, China

${ }^{13}$ Shanghai Urban Environmental Meteorology Center, Pudong New Area Weather Office, SMB, Shanghai, 200135, China

${ }^{14}$ Hangzhou Meteorological Bureau, Hangzhou, 310051, China

${ }^{15}$ Plateau Atmospheric and Environment Key Laboratory of Sichuan Province, College of Atmospheric Sciences, Chengdu

University of Information Technology, Chengdu, 610225, China

${ }^{16}$ State Key Laboratory of Numerical Modeling for Atmospheric Sciences and Geophysical Fluid Dynamics (LASG),

Institute of Atmospheric Physics, Chinese Academy of Sciences, Beijing, 100029, China

Correspondence to: H. Che (chehz@cams.cma.gov.cn) and X.-Y. Zhang (xiaoye@ cams.cma.gov.cn)

Received: 20 March 2015 - Published in Atmos. Chem. Phys. Discuss.: 29 April 2015

Revised: 25 June 2015 - Accepted: 30 June 2015 - Published: 14 July 2015

\begin{abstract}
Long-term measurements of aerosol optical depths (AODs) at $440 \mathrm{~nm}$ and Ångström exponents (AE) between 440 and $870 \mathrm{~nm}$ made for CARSNET were compiled into a climatology of aerosol optical properties for China. Qualityassured monthly mean AODs are presented for 50 sites representing remote, rural, and urban areas. AODs were 0.14 , $0.34,0.42,0.54$, and 0.74 at remote stations, rural/desert regions, the Loess Plateau, central and eastern China, and urban sites, respectively, and the corresponding $\mathrm{AE}$ values
\end{abstract}

were $0.97,0.55,0.82,1.19$, and 1.05 . AODs increased from north to south, with low values $(<0.20)$ over the Tibetan Plateau and northwestern China and high AODs ( $>0.60)$ in central and eastern China where industrial emissions and anthropogenic activities were likely sources. AODs were $0.20-0.40$ in semi-arid and arid regions and some background areas in northern and northeastern China. AEs were $>1.20$ over the southern reaches of the Yangtze River and at clean sites in northeastern China. In the northwestern deserts 
and industrial parts of northeast China, AEs were lower $(<0.80)$ compared with central and eastern regions. Dust events in spring, hygroscopic particle growth during summer, and biomass burning contribute the high AODs, especially in northern and eastern China. The AODs show decreasing trends from 2006 to 2009 but increased $\sim 0.03$ per year from 2009 to 2013.

\section{Introduction}

Aerosol particles are important for global and regional climate because particulate matter (PM) can scatter or absorb solar radiation, depending on the particles' composition, size, etc. (Charlson et al., 1992) and cause either large-scale cooling or warming (Hansen et al., 1997). Despite the numerous studies that have been conducted in recent years, aerosol optical properties are still one of the largest sources of uncertainty in current assessments and predictions of global climatic change (IPCC, 2013, 2007; Hansen et al., 2000; Ramanathan et al., 2001).

Satellite monitoring and ground-based observations are two important ways for monitoring the Earth's aerosol properties long-term (Holben et al., 2001). Ground-based measurement networks are especially useful for validating and augmenting remotely sensed data (Holben et al., 2001).

So far, several automatic robotic ground-based networks have been established; these include the Cimel sun photometer based AERONET federated network (Holben et al., 1998) composed of national, regional and global networks such as PHOTONS (Goloub et al., 2007), AEROCAN (Bokoye et al., 2001), RIMA (Prats et al., 2011) among many individual and institutional contributions, the PREDE-based sky radiometer network (SKYNET, Kim et al., 2004; Uchiyama et al., 2005), the WMO GAW PFR Network (Wehrli, 2002), and others.

Information on aerosol optical properties obtained from these networks contribute to our understanding of the Earth's systems because it can be used to (1) characterize the ambient aerosol, (2) address larger questions concerning environmental pollution, (3) validate satellite retrievals and numerical modeling algorithms, and (4) investigate aerosol and cloud effects on radiative fluxes (Holben et al., 2001). China is the most populated and largest developing country in the world, and it has become one of the largest global sources for aerosol particles and their precursors due to the copious industrial emissions and frequent dust events (Huebert et al., 2003; Seinfeld et al., 2004; Li et al., 2007). These aerosol particles not only affect the local atmospheric environment but also are transported to the East Asia and Pacific regions and beyond (Streets et al., 2001; Eck et al., 2005) where the transported materials can cause significant effects on regional weather and climate and also human health (Che et al., 2005; Liang and Xia, 2005; Xia, 2010; Chen et al., 2011).
Ground-based sunphotometers were first used to retrieve aerosol optical data in China in the early 1980s (Zhao et al., 1983; Qiu et al., 1983; Mao et al., 1983). Since then, there have been many investigations into aerosol optical properties, and studies have been conducted in northern China, northeast China, the Tibetan Plateau, northwest desert region and eastern coast region of China, etc. (Wang and Qiu, 1988; $\mathrm{Li}$ and $\mathrm{Lu}, 1995$; $\mathrm{Hu}$ et al., 2001; Zhang et al., 2002; Xia et al., 2005; Tan et al., 2009). These studies have provided valuable information on local aerosol optical properties, but they were carried out at different times with different instruments, and more often than not, used different calibration procedures, calculation algorithms, and so forth. This lack of standardization has made it difficult to characterize regional and temporal variations in aerosol optical properties. Accordingly, Qiu (1998) and Qin et al. (2010) proposed methods to retrieve AOD based on surface-based broadband solar radiation and horizontal visibility observation data. Long-term measurements of AODs and their distributions were retrieved in China from 1960s to 2000s (Qiu and Yang, 2000; Luo et al., 2001; Qin et al., 2010).

Ground-based networks for measuring aerosol optical properties in China were first established in the 1990s. Zhang et al. (2002) studied aerosol optical properties at four sites - Miyun, Xinfeng, Waliguan, and Dangxiong. Several SKYNET sites including Dunhuang, Yinchuan, Beijing, Qingdao, and Hefei in northern China were established from 1997 (Kim et al., 2004). At present, SKYNET has expanded to 10 sites in China, and a series of studies on optical properties and radiative forcing over different regions in China has been undertaken for that program (Kim et al., 2005; Che et al., 2008, 2014; Liu et al., 2011; Wang et al., 2014). Another network, the Chinese Sun Hazemeter Network (CSHNET) includes 24 stations established in 2004 to measure aerosol optical properties and their spatial and temporal variations throughout China. Hand-held sunphotometers have been used for that program (Xin et al., 2007; Wang et al., 2011). AERONET/PHOTONS established four sites in Beijing and Yulin beginning in 2001, (Alfaro et al., 2003; Fan et al., 2006; Che et al., 2009b), and there are now $\sim 40$ AERONET and PHOTONS sites in China (http://aeronet.gsfc.nasa.gov/ cgi-bin/type_piece_of_map_opera_v2_new); and the data from those sites have been widely used (Xia et al., 2005; Z. Q. Li et al., 2007; Mi et al., 2007; B. Li et al., 2009; Eck et al., 2010; Bi et al., 2011; Chen et al., 2012; Logan et al., 2013a). However, observations at most of these sites were only for field-campaigns (Cheng et al., 2006), and only several sites have data records long enough to characterize seasonal variations in aerosol optical properties (Chaudhry et al., 2007; Yu et al., 2011; Zhu et al., 2014; Fan et al., 2015). Indeed, the existing data are inadequate for a comprehensive evaluation of aerosol properties in China (Eck et al., 2005).

CARSNET is a ground-based network for monitoring aerosol optical properties, and it uses the same types of instruments as AERONET (Che et al., 2009c). CARSNET 
includes 20 sites located northern and northwestern China that were first established by the China Meteorological Administration (CMA) in 2002 for dust aerosol monitoring. This network has increased to more than 60 stations that are now operated not only by CMA but also by local meteorological administrations, institutes, and universities throughout China. This has become a national resource for studying aerosol optical properties over the different regions in China and for validating satellite retrievals and numerical models of aerosols (Xie et al., 2011; Zhou et al., 2012; Zhao et al., 2013; Che et al., 2014, 2015a, b; Lin et al., 2014; Xue et al., 2014; Zhuang et al., 2014; Cheng et al., 2015; Wu et al., 2015; Zhang et al., 2015).

The primary objective of this paper is to present a climatology of aerosol optical properties developed from CARSNET measurements made from 2002 to 2013. This study characterizes the spatial and temporal variations of aerosol optical properties using data from 50 CARSNET sites with at least 1 year of measurements. Remote, rural and urban regions of China are all represented in the study. The contents of this article include the following: (1) a description of the sites, data processing, and data quality control, (2) an evaluation of the spatial characteristics of AOD and Angström exponent over different regions of China, and (3) an analysis of the monthly AODs at $440 \mathrm{~nm}$ and the Ångström exponents between 440 to $870 \mathrm{~nm}(\mathrm{AE})$ at all 50 sites, (4) a discussion of the longterm (12 years) variations of AOD at 12 CARSNET sites. To provide a record of CARSNET results, monthly and yearly average AODs and AEs for the 50 CARSNET sites are provided as an Appendix. We hope this database will be used for future investigations of aerosols, climate, and the atmospheric environment of China.

\section{Site description, instruments, and data}

\subsection{Site descriptions}

As shown in Fig. 1 and described in detail in Appendix A, Cimel sun photometers (Cimel Electronique, CE-318) were installed at 50 CARSNET sites between 2002 to 2013. The stations can be classified into three general groups: remote, rural, and urban. The four remote stations were set up on the Tibetan Plateau (> $3000 \mathrm{~m}$ above sea level, a.s.l.) and at regional background site in northwest China, and all these sites are far from anthropogenic influences. The 25 rural sites were selected to be representative of areas relatively unaffected by local sources and well above the surrounding ground surface. The rural sites can be further classified as sites representing (a) desert regions (11 sites), which are mainly affected by dust aerosol particles with relatively small anthropogenic influences, (b) the Loess Plateau (4 sites) which are affected not only by dust but also by more anthropogenic activities than the nearby desert rural sites, (c) central and eastern China (10 sites) which are more strongly affected by anthropogenic ac-

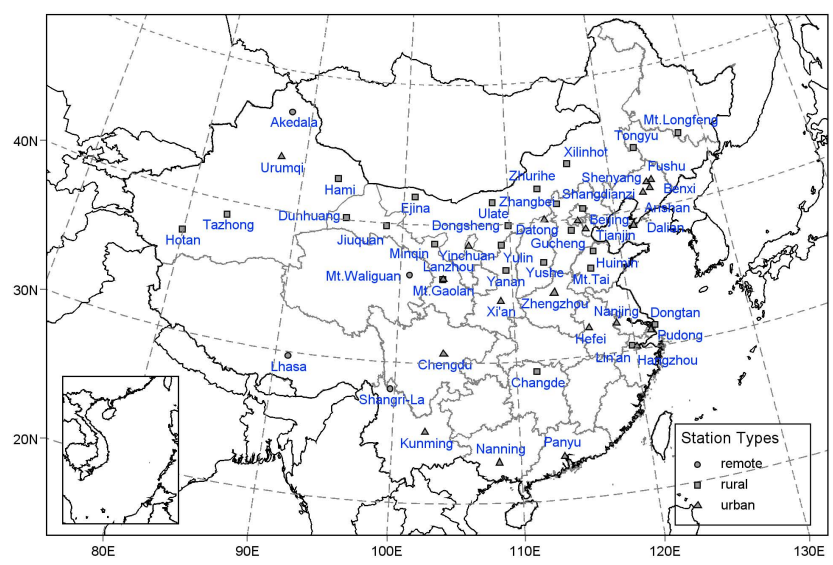

Figure 1. Locations of the 50 CARSNET sites in China.

tivities and are located near or surrounded by large cities, and urban sites (21 sites) located in the centers or heavily populated areas of cities, many of which are provincial capitals.

\subsection{Instruments and calibration}

Cimel sun photometers were deployed at each CARSNET site. These instruments make direct spectral solar radiation measurements in a $1.2^{\circ}$ full field of view every 15 min (Holben et al., 1998). Because the network has been expanded from the original 20 sites to 50 sites at present, several different types of Cimel instruments have been used; these include the following: (1) logical type at five normal wavelengths of $440,675,870,940$, and $1020 \mathrm{~nm}$ and three polarization bands at $870 \mathrm{~nm}$, (2) numerical type at five normal wavelengths of $440,675,870,940$, and $1020 \mathrm{~nm}$ and three polarization bands at $870 \mathrm{~nm}$, (3) numerical type at eight wavelengths of 340, 380, 440, 500, 675, 870, 940, and $1020 \mathrm{~nm}$, (4) and numerical type at nine wavelengths of 340,380 , $440,500,675,870,940,1020$ and $1640 \mathrm{~nm}$. Measurements at $340,380,440,500,675,870,1020$, and $1640 \mathrm{~nm}$ were used to retrieve AODs, and measurements at $940 \mathrm{~nm}$ were used to obtain the total precipitable water content in centimeters (Holben et al., 1998; Dubovik and King, 2000). The total uncertainty in the AODs is about 0.01 to 0.02 (Eck et al., 1999). Aerosol size distributions, refractive indices, and single-scattering albedos were retrieved by using sky radiance almucantar measurements and direct sun measurements following the procedures described in Dubovik et al. (2000, 2006). The inter-comparison between AERONET results and CARSNET ones show good consistencies. There are already some retrieval results about SSA and size distributions for some CARSNET sites for the research of urban pollution events (Che et al., 2014; Wu et al., 2015; Cheng et al., 2015). For all sites data processing, it is conducting to date.

Five CARSNET master quality sunphotometers were calibrated using the Langley method at the either the Izaña, Spain $\left(28.31^{\circ} \mathrm{N}, 16.50^{\circ} \mathrm{W}, 2391.0 \mathrm{~m}\right.$ a.s.1.) or the 
Mauna Loa, USA $\left(19.54^{\circ} \mathrm{N}, 55.58^{\circ} \mathrm{W}, 3397.0\right.$ ma.s.1. $)$ global observatories which are the master calibration sites for PHOTONS (also RIMA) and AERONET. These reference instruments were typically re-calibrated at Izaña every 6 months. These master instruments were then installed at the Beijing-CAMS site $\left(39.93^{\circ} \mathrm{N}, 116.32^{\circ} \mathrm{E}, 106.0\right.$ ma.s.l., which is operated for both CARSNET and AERONET), and they were used to inter-calibrate all field CARSNET instruments at least once a year following the AERONET calibration protocol (Che et al., 2009c).

The requirements for inter-comparison calibration protocol for the CARSNET field instruments were as follows: (a) only raw data collected from 02:00 to 06:00 a.m. (GMT + 08:00) on clean and clear days were used; (b) the AODs at $500 \mathrm{~nm}$ (the master instruments have nine wavelengths at $340,380,440,500,670,870,940$, 1020 , and $1640 \mathrm{~nm}$. Thus the masters could be used for the inter-calibration of all types of Cimel field instruments of CARSNET.) on calibration days had to be less than 0.20 and without major fluctuations; (c) the time intervals between the measurements made with two masters and the instruments to be calibrated had to be less than $10 \mathrm{~s}$. The AODs obtained from un-calibrated instruments differed by 4.5 to $15.3 \%$ compared with those measured by reference instruments. After the calibration with the master instruments, however, the daily average AODs differed by $<1.5 \%$ relative to the master measurements (Che et al., 2009c). According to Holben et al. (1998), yearly calibrations of the field instruments ensured the accuracy of the CARSNET measurements, and therefore, the AODs from the 50 CARSNET stations were of high quality and reliable.

The sphere calibration methods and protocols for CARSNET have been described by Tao et al. (2014). The CARSNET sphere calibration results differed from the original values provided by the manufacturer, Cimel Electronique, S.A.S., by $\sim 3-5 \%$ at infrared wavelengths (1020 and $870 \mathrm{~nm})$ and $\pm 3 \%$ at visible wavelengths $(440,500$, and $675 \mathrm{~nm}$ ). Similar to Holben et al. (1998), sphere calibrations of all CARSNET field instruments were done annually to ensure the accuracy of the sky irradiance measurements.

\subsection{Data processing and quality control}

The AODs were calculated using the ASTPWin software provided by the manufacturer of the sunphotometers. This software can provide Level 1.0 AOD (raw results without cloud screening), Level 1.5 AOD (cloud-screened AOD based on the work of Smirnov et al., 2000) and Ångström Exponents (AE) between 440 to $870 \mathrm{~nm}$. For the present study, all AOD data were computed by interpolation of the intercalibration coefficients. The interpolation was performed for daily averages based on the annual inter-calibration coefficients. And the cloud-screened AOD based on the method of Smirnov et al. (2000) also were obtained. We note that the cloud-screening technique has not been completely val-
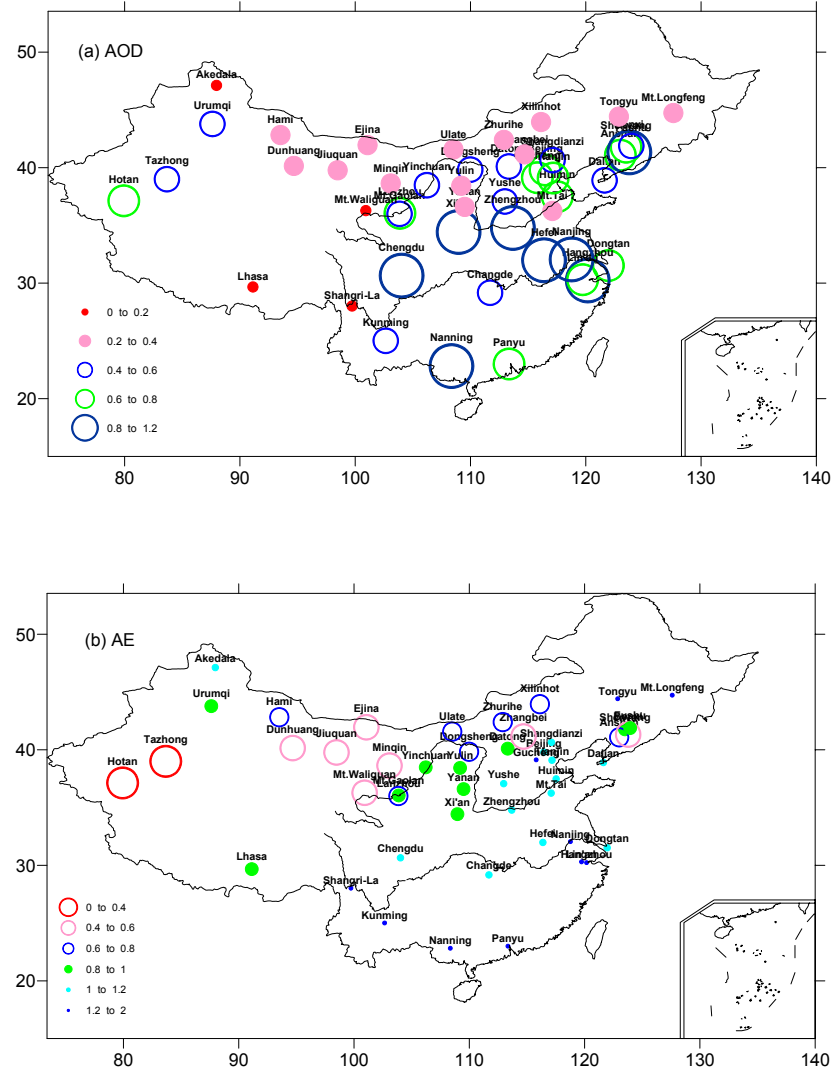

Figure 2. Spatial distributions of (a) AOD at $440 \mathrm{~nm}$ and (b) $\mathrm{AE}$ between 440 and $870 \mathrm{~nm}$ based on CARSNET measurements.

idated although the procedure tested favorably using experimental data obtained under different geographical and optical conditions (Smirnov et al., 2000). To further ensure the data quality, all the data were checked manually site by site, and any unreasonable data were deleted. For example, some exceptionally large AOD points were caused by the clouds, and this was determined after checking the MODIS Level-1B granule (MOD02_1km) images, which are available from http://modis-atmos.gsfc.nasa.gov/IMAGES/. Daily average AODs were the first values computed, and any cases where measurements were made less than 10 times in a day were eliminated. This processing procedure eliminated $\sim 20 \%$ of the daily data. Finally, the monthly and yearly averages of the AODs were calculated at each wavelength as were the Ångström exponents between 440 and $870 \mathrm{~nm}$.

Che et al. (2009c) validated AODs from CARSNETCAMS stations through comparisons with data from the AERONET stations in Beijing. A comparison between the AODs calculated by ASTPWin procedure versus AERONET results, showed that the ASTPWin AOD values were about $0.03,0.01,0.01$, and 0.01 larger than those from AERONET at $1020,870,670$, and $440 \mathrm{~nm}$, respectively. Thus, the sets of results from two networks were very consistent with one another as the correlation coefficients were larger than 
0.999 and had a $99.9 \%$ significance level. Synchronous observations also were compared between two nearby Yangtze River Delta region sites, one at the AERONET Zhejiang Forest University site and the other the Lin'an regional CARSNET background site (Pan et al., 2010). The differences of AOD in that comparison were less than 0.02, which again indicates similar accuracies in the results from CARSNET and AERONET.

\section{Results: CARSNET measurements}

\subsection{Spatial distributions of aerosol optical properties in China}

\subsubsection{Spatial distributions of AOD and $\mathrm{AE}$}

The spatial distribution of AOD at $440 \mathrm{~nm}$ (Fig. 2a) and AE between 440 and $870 \mathrm{~nm}$ (Fig. 2b) based on data obtained from the CARSNET stations are shown in Fig. 2. In general, the AODs increased from north to south (Fig. 2a). Low AODs $(<0.20)$ occurred at remote stations, that is, Mt. Waliguan, Shangri-La, and Lhasa on the Tibetan Plateau at altitudes $>3000 \mathrm{~m}$ a.s.l. and at Akedala in a remote region of northwestern China. All of the remote sites are subject to only minimal anthropogenic influences, and the aerosol loadings are very low because of this (Zhang et al., 2012). Large AODs (>0.60) mainly occurred in central and eastern China, especially regions with strong anthropogenic influences in the northeastern plain, North China Plain, Yangtze River Delta, Pearl River Delta, Sichuan Basin, and Guanzhong Plain (Zhang et al., 2012). Several sites in northwestern China also showed AOD $>0.60$; these include the urban site at Lanzhou and desert-margin site at Hotan, Xinjiang province. AODs from 0.20-0.40 occurred in semi-arid and arid regions of northern China and some regional background sites such as Mt. Tai - the background site for the North China Plain and Mt. Longfeng - the background site on the Northeast China Plain.

From Fig. 2b, we can see that the spatial distribution of $\mathrm{AE}$ in China also shows clear variability, for example large $\mathrm{AE}(>1.20)$ were found along the southern reaches of the Yangtze River and at clean sites of northeastern China; this shows that the aerosol particles in these areas are smaller than in most other regions of China. On the other hand, there is very high $\mathrm{AOD}$ in the southern China sites, whereas in the northeastern sites AOD is smaller. This indicates very absorbing particles in the former respect to the latter. The investigation (not shown here) showed that the SSA of urban area in Yangtze River region is obviously lower than the suburban ones which suggests the absorbing particles in urban areas are more than suburban clean ones. In the desert regions of northwestern China and industrial region of northeastern China, the AE values were considerably lower $(<0.80)$ than those of central and eastern regions such as North China
Plain, Guanzhong Plain and Sichuan Basin (AE > 0.80). The $\mathrm{AE}$ values were $\sim 0.60-0.80$ in arid regions of northern China. In particular, the AEs were typically $<0.40$ in the Taklimakan Desert region (e.g., Tazhong and Hotan) which suggests that large mineral dust particles were major components of the aerosol populations in this region (Che et al., 2013).

Figure 3 shows the spatial distributions of AOD and AE separately for each of the four seasons. Of the 50 CARSNET sites, 27 had AODs $<0.60$ in spring and summer compared with 32 in the fall and 30 in winter (Fig. 3a-d), and this shows that the aerosol extinctions of China were generally larger in spring and summer compared with fall and winter. Moreover, most of the sites with AODs $<0.60$ were located in northern China. In southern China, AODs $<0.40$ occurred only at one site, Kunming, and then only in fall and winter. The AOD is larger than 0.60 all year round, which is mainly due to the local emissions. Nanning is the capital city of Guangxi Zhuang Autonomous Region of China with more than 7 million people and 1 million vehicles there. Moreover, it belongs to the geophysical characteristics of the basin. The high AOD could be related to this special geographical characteristic, which is against pollution diffusion. Monthly average AODs $>0.60$ were found in central and eastern China all year round. The AODs in the Taklimakan Desert region were $>0.60$ in spring and summer but $<0.60$ in fall and winter, and this pattern can be explained by the frequent dust storms in spring and summer and fewer dust events in fall and winter (Gong et al., 2003; Eck et al., 2005). It was also found that the AODs were $<0.40$ at the sites near the boundary between China and Mongolia, and this was true throughout the year. There also were more sites with low AODs, that is $<0.20$, in fall (6 sites) and winter (9 sites) compared with spring (2 sites) and summer (3 sites).

The spatial distributions of $\mathrm{AE}$ for the four seasons are presented in Fig. 3f-i. Eck et al. (2005) suggested that coarse mode aerosols were relatively more abundant when $\mathrm{AE}$ was less than 0.80. In this study, there were 24, 10, 14, and 15 sites with $\mathrm{AE}<0.60$ in spring, summer, fall, and winter season, respectively, and almost all of these sites are located in northern China. This reflects the presence of coarse dust particles transported from semi-arid and arid regions of northwestern and northern China (Zhang et al., 2012). AE $>0.80$ were found in central and east China from summer to winter and in south China all year round, suggesting that the particle size distributions favored the fine mode.

In spring, there were many sites with AE $0.80-1.00$ in central China and 1.00-1.20 in the Yangtze River Delta region, and these values were obviously lower than in the other seasons when they were typically $>1.20$. These results reflect the transport of large dust particles from northwest China to eastern China during the spring (Chen et al., 2009). As for the Taklimakan Desert region itself, AEs were $<0.40$ from spring to fall and $0.40-0.60$ in winter, and this implies the presence of coarse mode aerosols throughout the year, with 

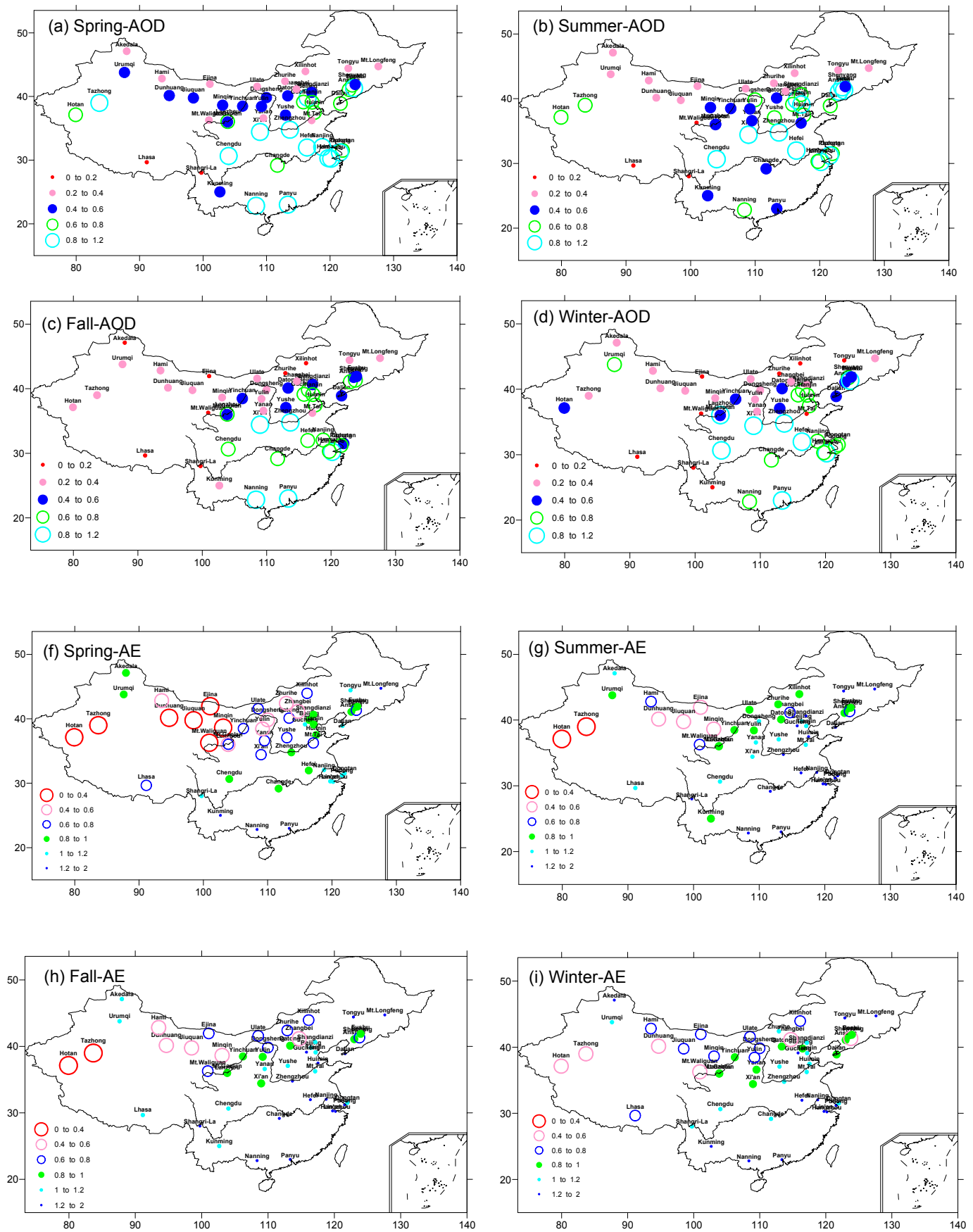

Figure 3. Seasonally stratified spatial distributions of AOD at $440 \mathrm{~nm}$ (a spring; b summer; $\mathbf{c}$ fall; and d winter) and AE between 440 and $870 \mathrm{~nm}$ (e spring; $\mathbf{f}$ summer; $\mathbf{g}$ fall; and $\mathbf{h}$ winter) based on CARSNET measurements.

greater impacts of fine-particle pollution sources in winter (Che et al., 2013). For southern China, including the stations at Nanning and Panyu, AE was $>1.20$ all year, and this reflects the dominance of fine mode particles caused by the chronic anthropogenic emissions in the region (Tan et al., 2009).

\subsubsection{Aerosol optical properties in remote, rural, and urban regions of China}

From Fig. 4a and b, one can see small AODs at the four remote sites of Akedala, Lhasa, Mt. Waliguan, and ShangriLa. Indeed, the AODs at these sites were 0.11-0.18, with an arithmetic mean of $0.14 \pm 0.04$. The Ångström exponent varied from 0.59 at Mt. Waliguan to 1.29 at Shangri-La and 

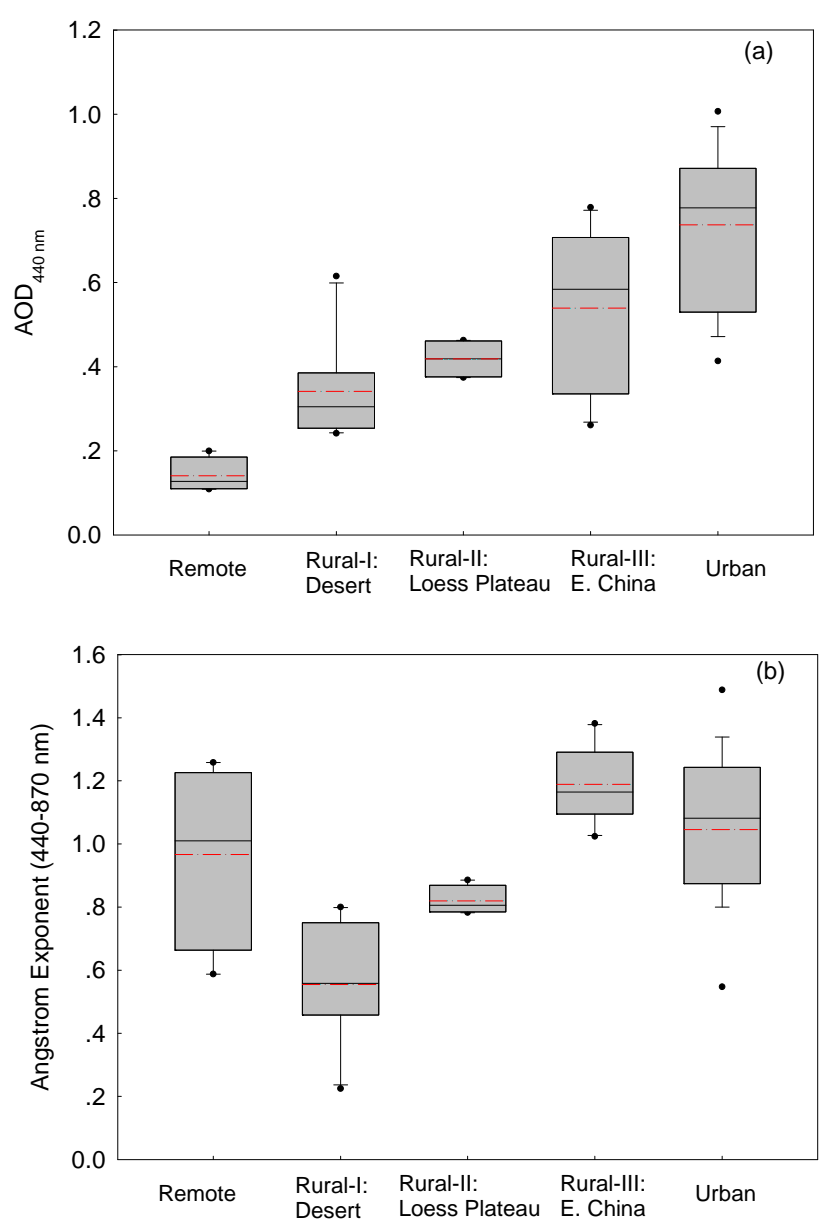

Figure 4. (a) AODs at $440 \mathrm{~nm}$ and (b) AEs between 440 and $870 \mathrm{~nm}$ at remote, rural, and urban regions of China.

averaged $0.97 \pm 0.29$. These results are generally representative of the aerosol optical properties at background regions in the interior of Asia. Che et al. (2011) reported that the AOD at $500 \mathrm{~nm}$ at Mt. Waliguan averaged $\sim 0.14$ from September 2009 to August 2010, and this is similar to the long-term measurements reported here $(\mathrm{AOD}=0.14 \pm 0.06$ at $440 \mathrm{~nm}$ and Ångström exponent $=0.59 \pm 0.21$ from March 2009April 2012).

The AODs for 11 rural stations in desert regions varied from 0.23 to 0.61 and averaged $0.34 \pm 0.12$. Although some stations, such as Ejina, Jiuquan, Dunhuang, and Minqin, near desert regions are known to be frequently affected by springtime dust storms, the average AODs were not as large as one might expect. In fact, the AODs at most of these sites were $<0.40$ except for Tazhong $(\mathrm{AOD}=0.53 \pm 0.28)$ and Hotan $(\mathrm{AOD}=0.61 \pm 0.22)$. These two stations are located in Taklimakan Desert region, one of the world's largest sources for desert dust (Zhang et al., 2003; Che et al., 2013). The AEs over the rural desert stations varied from $0.22-0.80$ and averaged $0.55 \pm 0.19$, and these values reflect the light extinction properties of coarse dust particles.
The four rural stations located on the Chinese Loess Plateau (CLP) showed ranges in the AODs and AEs of 0.370.46 and $0.79-0.89$, respectively, and means of $0.42 \pm 0.05$ and $0.82 \pm 0.05$. These values are consistent with the results reported by Bi et al. (2011) who studied aerosol optical properties at SACOL (Semi-Arid Climate and Environment Observatory of Lanzhou University) rural site on the CLP and reported AODs and AEs of $\sim 0.35$ and $\sim 0.92$, respectively. The average AODs and AEs at the CLP stations were higher than those over the desert regions $(0.34 \pm 0.12$ for AOD and $0.55 \pm 0.19$ for AE). This shows that the aerosol loadings over the Loess Plateau were greater compared with the desert regions and that there were relatively more fine particles. The numbers of persons living in and round the CLP sites are larger than those at the desert stations, and as a result more anthropogenic aerosols likely occurred over the CLP (Wang et al., 2010; Liu et al., 2011). In fact, earlier studies have shown that both anthropogenic emissions and dust storms do affect the aerosol populations of the CLP (Alfaro et al., 2003; Che et al., 2009b).

The AODs at 10 rural sites in central and eastern China show obviously higher AODs compared with stations located near the deserts or CLP. The average AOD and AE for the rural sites were $0.54 \pm 0.18$ and $1.19 \pm 0.12$, respectively. The AODs also varied over a large range, from 0.26 to 0.78 , and the AEs at all these sites were $>1.00$ and varied from 1.02 to 1.38 , suggesting a dominance of fine particles. The sites in eastern China are strongly influenced by anthropogenic emissions because even though their populations are relatively small, the sites are downwind of megacities. For example, the sites at Shangdianzi and Gucheng are near Beijing while Dongtan and Lin'an are near Shanghai (Che et al., 2009a).

The AODs for the urban CARSNET sites showed a range $0.40-1.00$ with an average $0.74 \pm 0.18$ while $\mathrm{AE}$ ranged from $0.52-1.50$ and averaged $1.05 \pm 0.23$. The large AOD and $\mathrm{AE}>1.00$ indicates the aerosol populations were predominantly composed of fine mode particles. However, the average AE for urban sites was lower than that of rural sites at eastern China, and this is probably due to the presence of fugitive dust. Fugitive dust refers to aerosol particles that are lifted into the air either by man-made or natural activities in urban open areas, which is typically the result from activities such as the physical movement of soil, vehicles traveling over unpaved surfaces, heavy equipment operation, blasting, and wind. Chen et al. (2010), for instance, pointed out that fugitive dusts from transportation, building construction, and burning garbage are a major component of the aerosol in metropolitan areas of China.

Figure 5 shows the seasonal variations in AOD (Fig. 5a-d) and AE (Fig. 5e-h) at the CARSNET remote, rural, and urban sites. In general, the AODs were lower at all three types of sites in fall and winter compared with spring and summer. The combined AODs in spring and summer were factors of 1.57, 1.62, 1.29, 1.18, and 1.14 to combined AODs in fall and winter at remote, rural, and urban sites, respectively. 

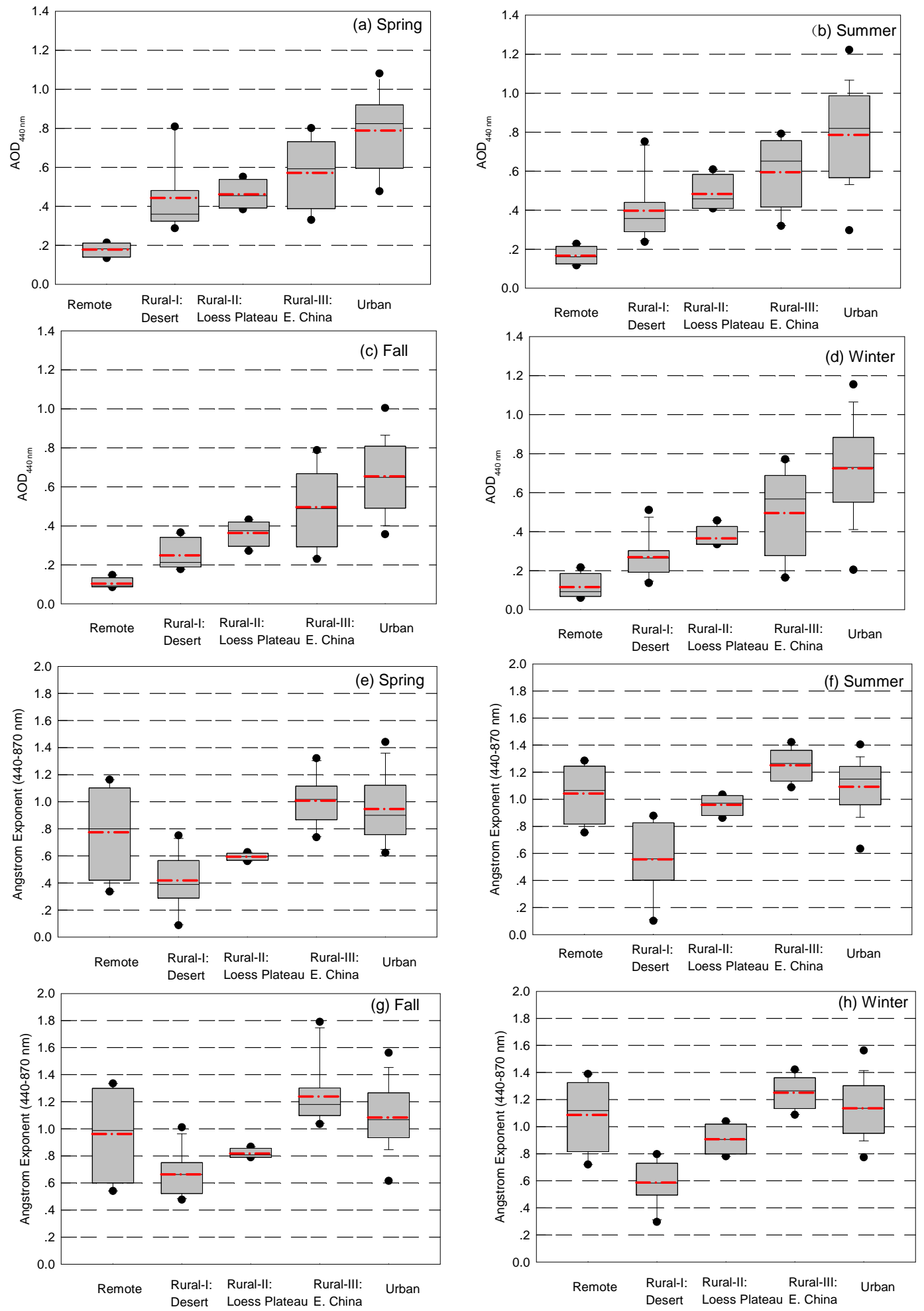

Figure 5. Seasonally averaged AODs at $440 \mathrm{~nm}(\mathbf{a}-\mathbf{d})$ and AEs between 440 and $870 \mathrm{~nm}(\mathbf{e}-\mathbf{h})$ at remote, rural, and urban regions of China. 

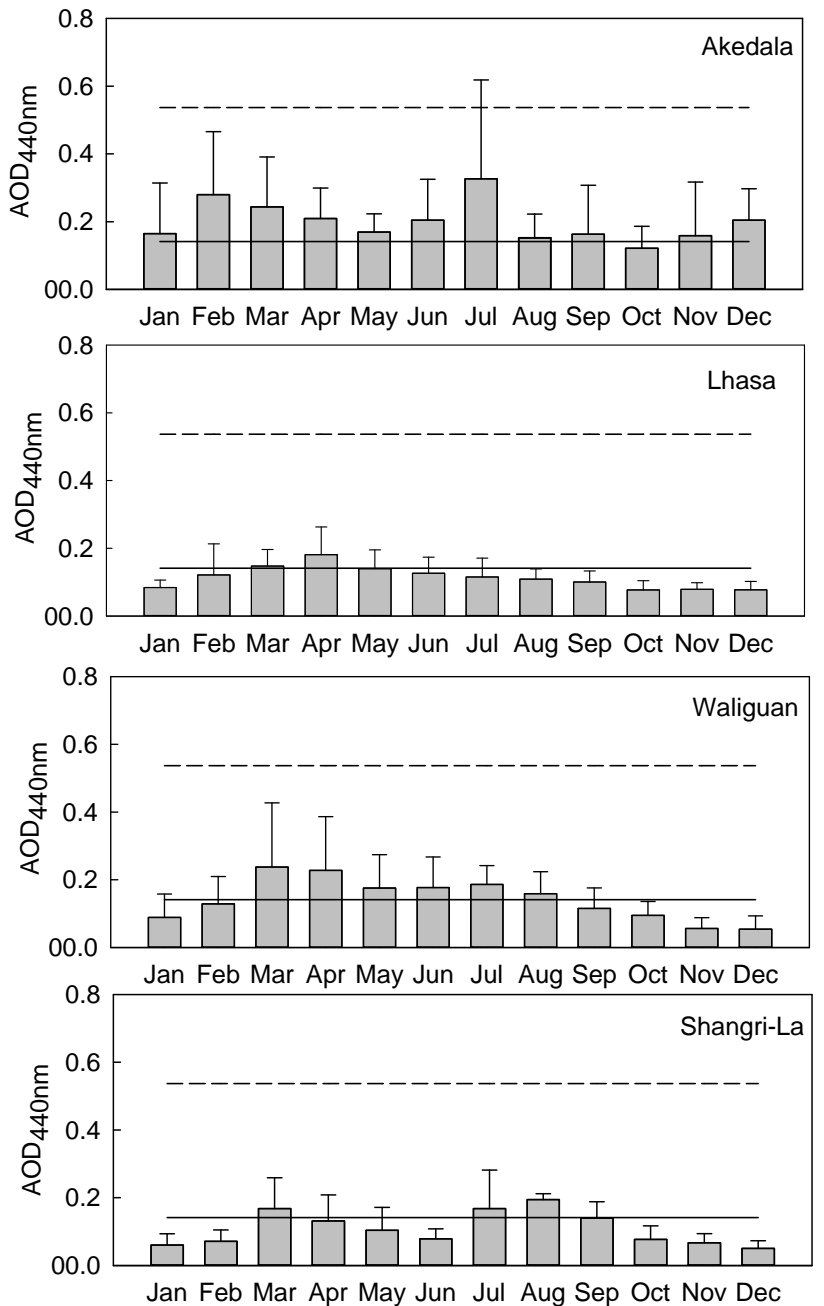

Figure 6. Monthly averaged AODs at $440 \mathrm{~nm}$ at remote sites. The solid and dash horizontal hairlines indicate the annual averages for the subgroup and the whole database, respectively.

However, the AEs in fall and winter were factors of 1.27, $1.28,1.11,1.10$, and 1.09 for spring and summer seasons. These comparisons show that the effects of dust particles on $\mathrm{AOD}$ and $\mathrm{AE}$ were more apparent at the remote and rural desert sites compared with the rural and urban sites.

\subsection{Temporal variations in AOD and AE}

\subsubsection{Monthly average AODs and variations in AE at remote sites}

Figure 6 shows the monthly averaged AODs at $440 \mathrm{~nm}$ at remote sites of CARSNET. The AODs at Akedala in northwest China showed high monthly means $(>0.20)$ from February to April, and this was presumably a consequence of the transport of mineral dust from the nearby Gobi, sand lands, and deserts as well as the deserts in eastern Kazakhstan. The AODs were lower from August to October when there was
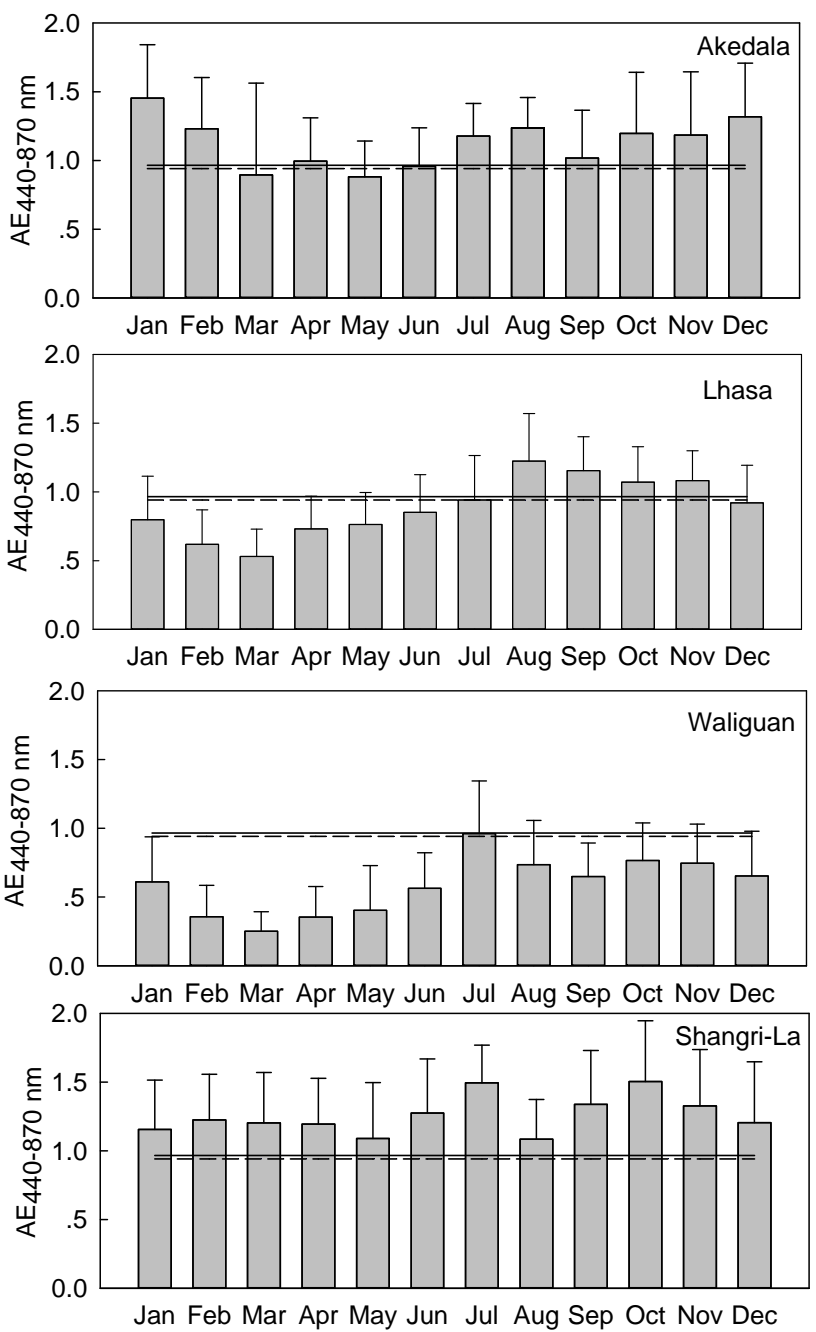

Figure 7. Monthly averaged AEs between 440 and $870 \mathrm{~nm}$ at remote sites. The solid and dash horizontal hairlines indicate the annual averages for the subgroup and the whole database, respectively.

more precipitation in the region and the winds were weaker. The AOD at Akedala was $>0.20$ in June and July, and this can be attributed to the transport of pollutants from countries in eastern Europe, western Russia, and eastern Kazakhstan, which are all upwind (Qu et al., 2008). The AODs increased from October to December, and that was probably a result of the local burning of coal for cooking and heating, which needs to be proven in the future combined with the chemical composition analysis.

The AODs in spring and summer were high and low in fall and winter at Lhasa and Mt. Waliguan, which are both on the Tibetan Plateau. Monthly average AODs at these two sites exceeded 0.15 in spring and 0.10 in summer, and they were $<0.10$ in fall and winter. The AODs reported here for Lhasa are slightly larger than those in a study by Cong et al. (2009), and this could be caused by year-toyear differences in the strengths and numbers of dust storms 
as well as local contributions from anthropogenic activities. The CARSNET Lhasa site is located in the city itself, while Nam Co station of AERONET is $125 \mathrm{~km}$ north of Lhasa city, where there are no impacts from local anthropogenic activities (Cong et al., 2009). The AODs at Mt. Waliguan $(0.14 \pm 0.06)$ were slightly larger than those at Shangri-La or Lhasa where the mean AOD values were $0.11 \pm 0.05$ and $0.11 \pm 0.03$, respectively. The AODs at Shangri-La in southwestern China also showed two seasonal peaks; that is, the AODs were $>0.10$ during March to May and again from July to September while in other periods, the AODs were $<0.10$. These small AODs at Shangri-La also show that even the maximum aerosol loadings in this region are very low compared with other regions in China.

Figure 7 shows the monthly averaged AEs between 440 and $870 \mathrm{~nm}$ at remote sites of CARSNET. In general, the monthly average AEs at Akedala and Shangri-La and were larger than those that at Mt. Waliguan and Lhasa, and this indicates that the aerosol particles tend to be smaller at the latter two sites. This is likely due to the fact that Mt. Waliguan is located on the northwestern margin of Qinghai-Tibet plateau and therefore subject to the transport of dust from desert regions in western China and middle Asia (Che et al., 2011; Gong et al., 2003). Lhasa also can be affected by mineral aerosol from deserts in western China and local dust uplifted from Tibetan Plateau. The monthly averages for AE at Akedala, Mt. Waliguan and Lhasa were lower in spring than other seasons: the minima at these three sites occurred in March, with values of $0.90 \pm 0.68,0.25 \pm 0.14$, and $0.53 \pm 0.12$, respectively. These low springtime AEs suggest that coarse particles from dust events were prevalent at these three sites. In summer and fall, the AEs were larger than in spring, with a maximum of $0.96 \pm 0.38$ in July at Waliguan and 1.22 \pm 0.35 in August at Lhasa. At Shangri$\mathrm{La}$ and Akedala, the AEs were $>0.80$ throughout the year, and therefore, fine mode particles were relatively abundant at these two sites.

\subsubsection{Variations in monthly AODs and AEs at the rural desert sites}

Most of the 11 rural CARSNET sites near the desert regions showed large AODs in spring and summer and low AODs in autumn and winter (Fig. 8), and this is evidence that the aerosol populations at these sites were affected by springtime dust events. In summer, the impacts from dust events weakened while anthropogenic emissions from central and western China evidently contributed to the aerosol loadings over these regions (Che et al., 2009a). In autumn and winter, dust storms are rare because low temperatures restrict convection even though incursions of cold air can bring strong winds. Hotan and Tazhong, the two rural sites located in Taklimakan desert, showed AOD $>0.40$ from February to October. The monthly averaged AODs were the lowest in November, $0.31 \pm 0.12$ at Hotan and $0.22 \pm 0.16$ at Tazhong. The four rural sites in desert regions of northwestern China each showed maximum AODs in April; these were $0.39 \pm 0.30$ at Ejina, $0.48 \pm 0.27$ at Minqin, $0.55 \pm 0.41$ at Dunhuang, and $0.55 \pm 0.40$ at Jiuquan. The minima occurred in fall or winter, with values of $0.14 \pm 0.08,0.20 \pm 0.09,0.17 \pm 0.04$ in November at Ejina, Dunhuang, Jiuquan, respectively, and $0.26 \pm 0.18$ in January at Minqin.

The four rural sites in the interior of Inner Mongolia showed generally similar variations in the AODs; that is, maxima in June of $0.44 \pm 0.39,0.39 \pm 0.30,0.49 \pm 0.43$, $0.45 \pm 0.26$ at Wulate, Xilinhot, Zhurihe, and Zhangbei, respectively. Minima in the AODs occurred in November at Ulate and Xilinhot with averages of $0.19 \pm 0.09$ and $0.16 \pm$ 0.09 , respectively, while the minima at Zhurihe $(0.11 \pm 0.05)$ and Zhangbei $(0.18 \pm 0.12)$ were in January. The low AODs in winter and autumn occurred when the ground surface was often frozen or covered by snow - conditions that would prevent the production of windblown dust.

Monthly average AEs at most of the rural desert sites, including Ejina, Zhangbei, Jiuquan, Dunhuang, Tazhong and Hotan, showed low values $(<0.80)$ all year in Fig. 9; and this indicates the coarse particles were the dominant aerosol components. As for other sites (Zhurihe, Hami, Xilinhot, Wulate, and Minqin), the AEs were $<0.80$ in March and April when dust events were common. The two sites in the Taklimakan showed low AEs $(<0.20)$ for more than 6 months (February to October), and therefore large dust particles affected these sites more than the others. In December and January, the AEs at most of the CARSNET rural desert sites were higher compared with the other types of sites, and this was likely due to presence of fine particles from coal and biomass burning as both used extensively for domestic heating (Eck et al., 2005).

\subsubsection{Variations in monthly average AODs and AEs at the rural sites on the Loess Plateau}

The monthly average AODs at the four sites on the Loess Plateau showed different temporal trends (Fig. 10). At Dongsheng, the AOD was $>0.40$ in spring and summer, and the monthly maximum $(0.71 \pm 0.44)$ occurred in June; and that was probably caused by the hygroscopic growth of particles in combination with gas-particle conversion processes (Eck et al., 2005). At Yan'an, the AOD varied smoothly around 0.35 from January to October, and it was $<0.30$ in November and December. At Mt. Gaolan the AODs in spring and winter were higher than in summer and autumn while at Yulin, the AODs were $>0.30$ from January to September. The seasonal variability in the aerosol at Yulin was likely caused by a mixture of dust and local anthropogenic emissions (Alfaro et al., 2003).

The AEs for the four sites on the CLP showed obvious seasonality, with $\mathrm{AE}<0.70$ from March to May but higher values $(\sim 0.85)$ in August. This is another indication that aerosol particles at these sites are affected both by dust events and anthropogenic activities (Fig. 11). 

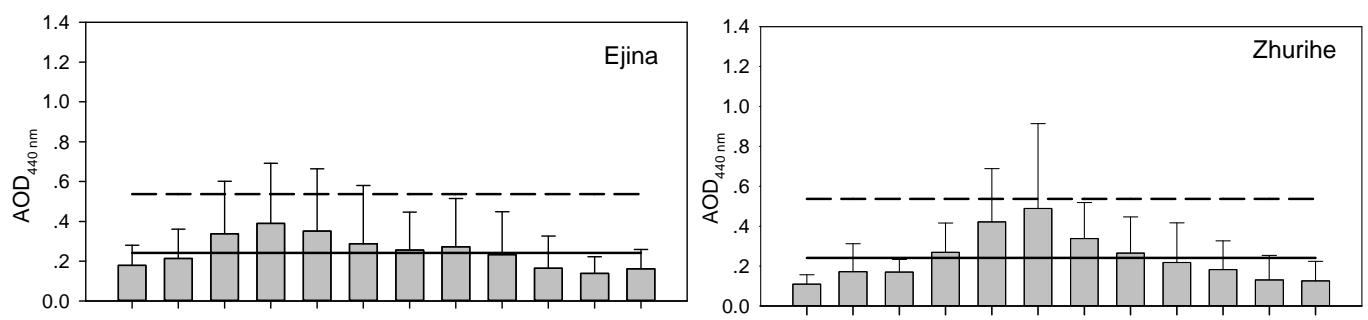

Jan Feb Mar Apr May Jun Jul Aug Sep Oct Nov Dec

Jan Feb Mar Apr May Jun Jul Aug Sep Oct Nov Dec
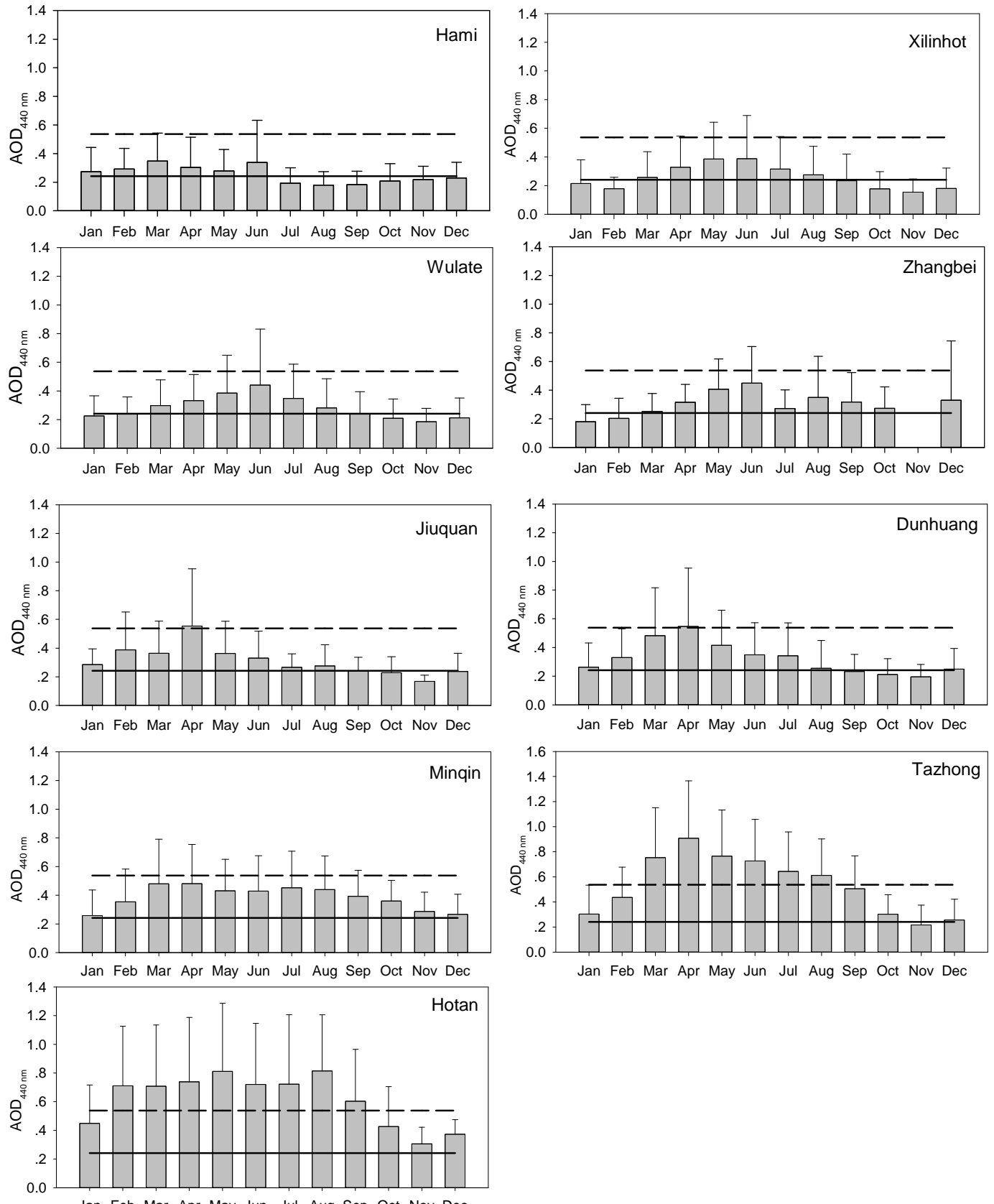

Jan Feb Mar Apr May Jun Jul Aug Sep Oct Nov Dec

Figure 8. Monthly averaged AODs at $440 \mathrm{~nm}$ at rural desert sites. The solid and dash horizontal hairlines indicate the annual averages for the subgroup and the whole database, respectively. 

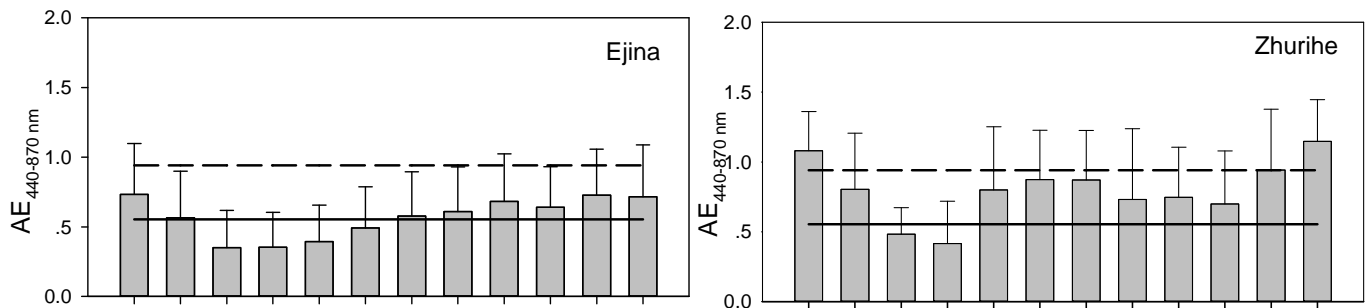

Jan Feb Mar Apr May Jun Jul Aug Sep Oct Nov Dec

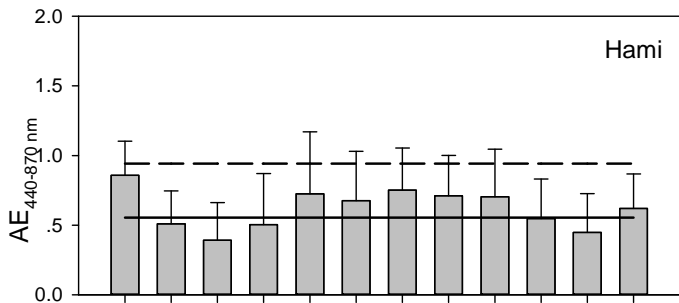

Jan Feb Mar Apr May Jun Jul Aug Sep Oct Nov Dec
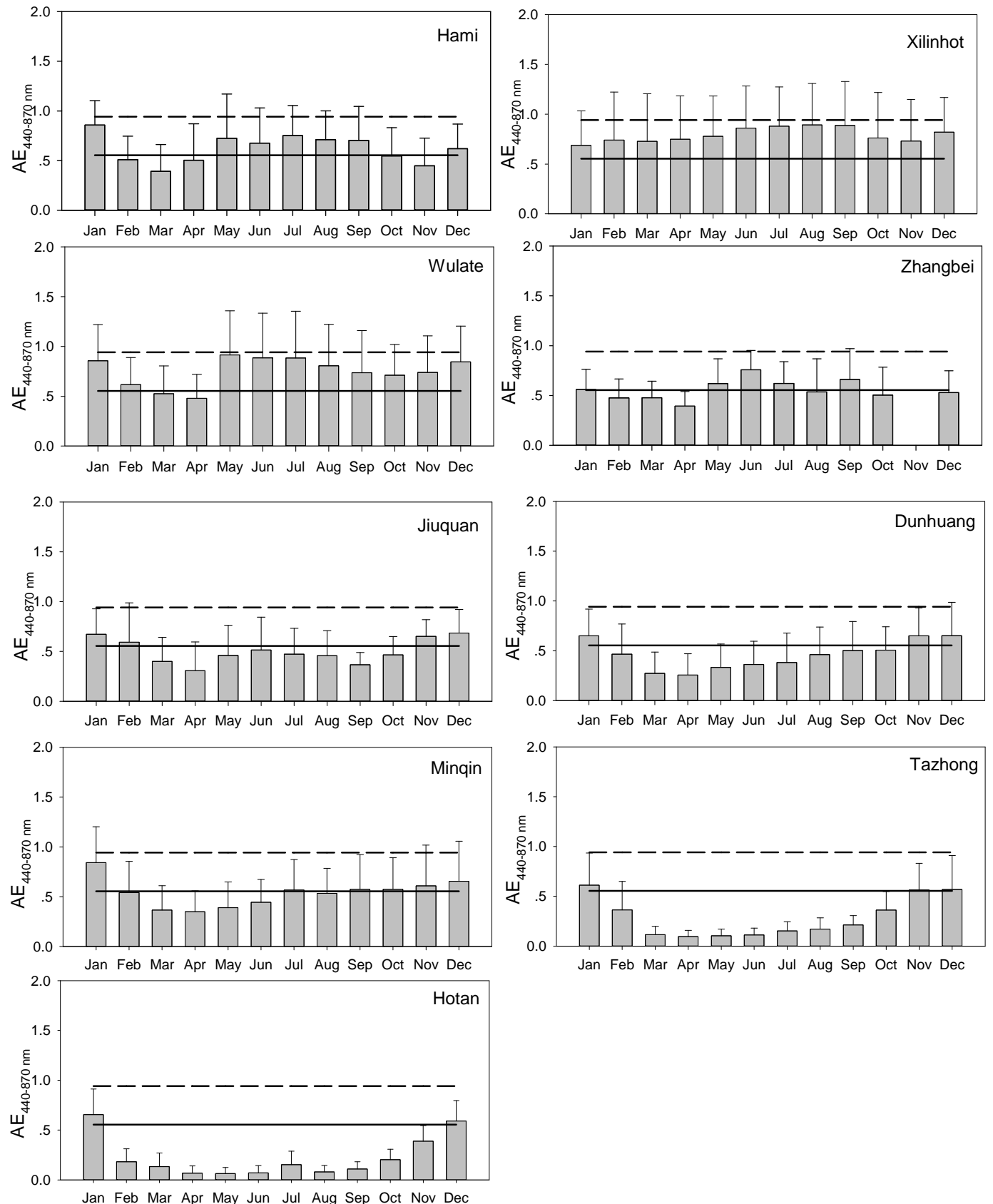

Jan Feb Mar Apr May Jun Jul Aug Sep Oct Nov Dec

Figure 9. Monthly averaged AEs between 440 and $870 \mathrm{~nm}$ at rural desert sites. The solid and dash horizontal hairlines indicate the annual averages for the subgroup and the whole database, respectively. 

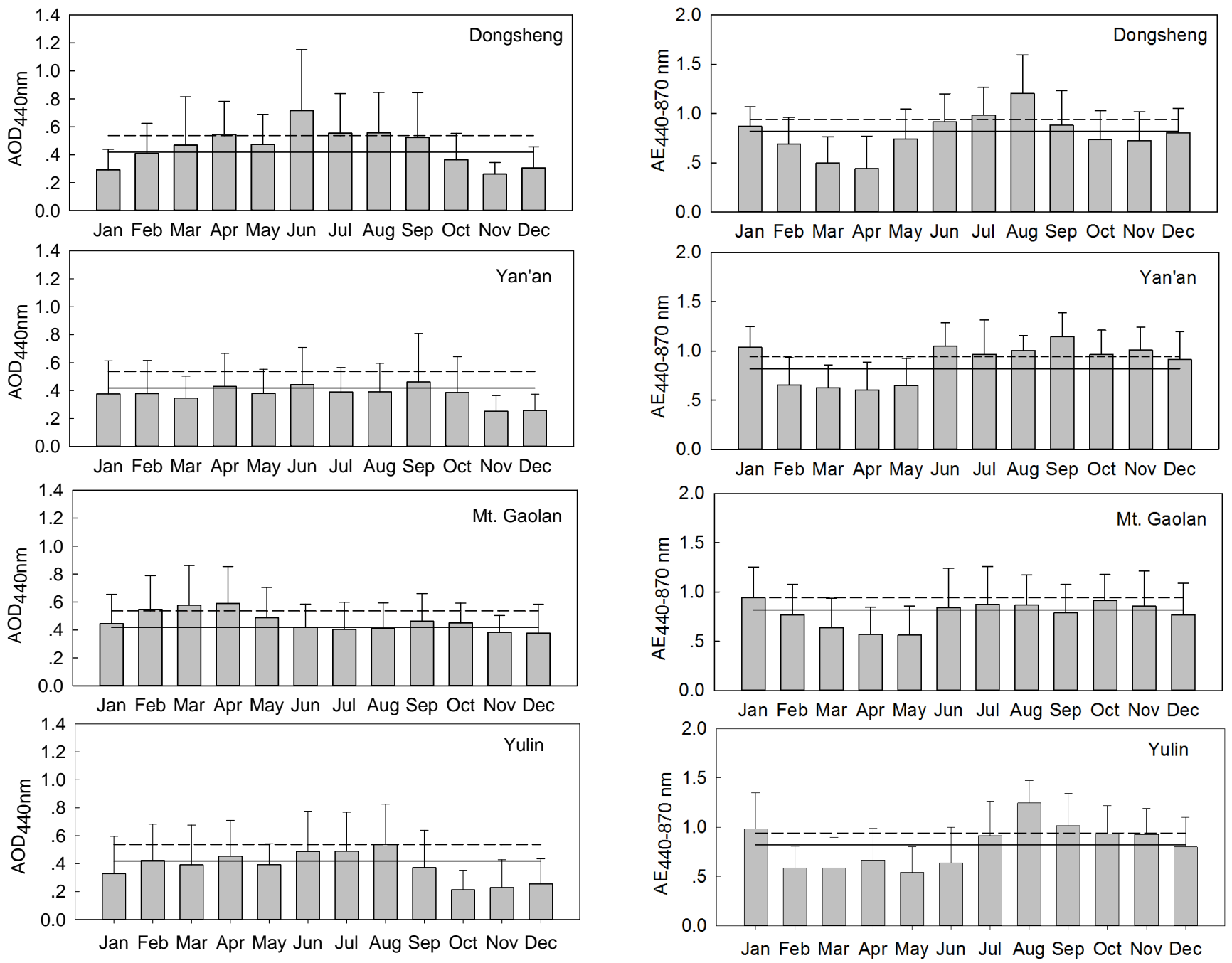

Figure 10. Monthly averaged AODs at $440 \mathrm{~nm}$ at rural Loess Plateau sites. The solid and dash horizontal hairlines indicate the annual averages for the subgroup and the whole database, respectively.

\subsubsection{Variations in the monthly average AODs and AEs at rural sites in central and eastern China}

Figure 12 shows the monthly averaged AODs at $440 \mathrm{~nm}$ at rural central and eastern China sites of CARSNET. These sites can be divided into three groups (1) Tongyu and Mt. Longfeng located in northeastern China; (2) Shangdianzi, Gucheng, Huimin, Yushe and Mt. Tai in the North China Plain; and (3) Changde, Lin'an, and Dongtan in the middle and lower reaches of the Yangtze River. The AODs at Mt. Longfeng and Tongyu in northeast China and Mt. Tai in northern China were $\sim 0.30$, which is lower compared with the rural stations in central and eastern China (Fig. 12). The AODs at Shangdianzi - the background site for the Beijing-Tianjin-Hebei (Jing-Jin-Ji) region was a factor of

Figure 11. Monthly averaged AEs between 440 and $870 \mathrm{~nm}$ at rural Loess Plateau sites. The solid and dash horizontal hairlines indicate the annual averages for the subgroup and the whole database, respectively.

$1.6(\sim 0.48)$ greater than at the three sites just discussed, indicating higher aerosol loadings in this region.

The AODs at Huimin, Gucheng and Yushe in the North China Plain ranged from $0.58-0.71$ as a result of the heavy pollution aerosol loadings there. This region of northern China is industrially developed, and biomass burning is also common, especially in June and from September to October (Eck et al., 2010). For Dongtan, Changde, and Lin'an, the sites in the Yangtze River region of southern China, the AODs were 0.59-0.78, and these were higher than in the North China Plain. Mt. Longfeng and Tongyu in northeastern China showed AODs $>0.35$ during April to June, and the springtime values were obviously higher compared with the other months.

In June, the AODs for the North China Plain and Yangtze River Delta station (Shangdianzi, Mt. Tai, Gucheng, Huimin, 

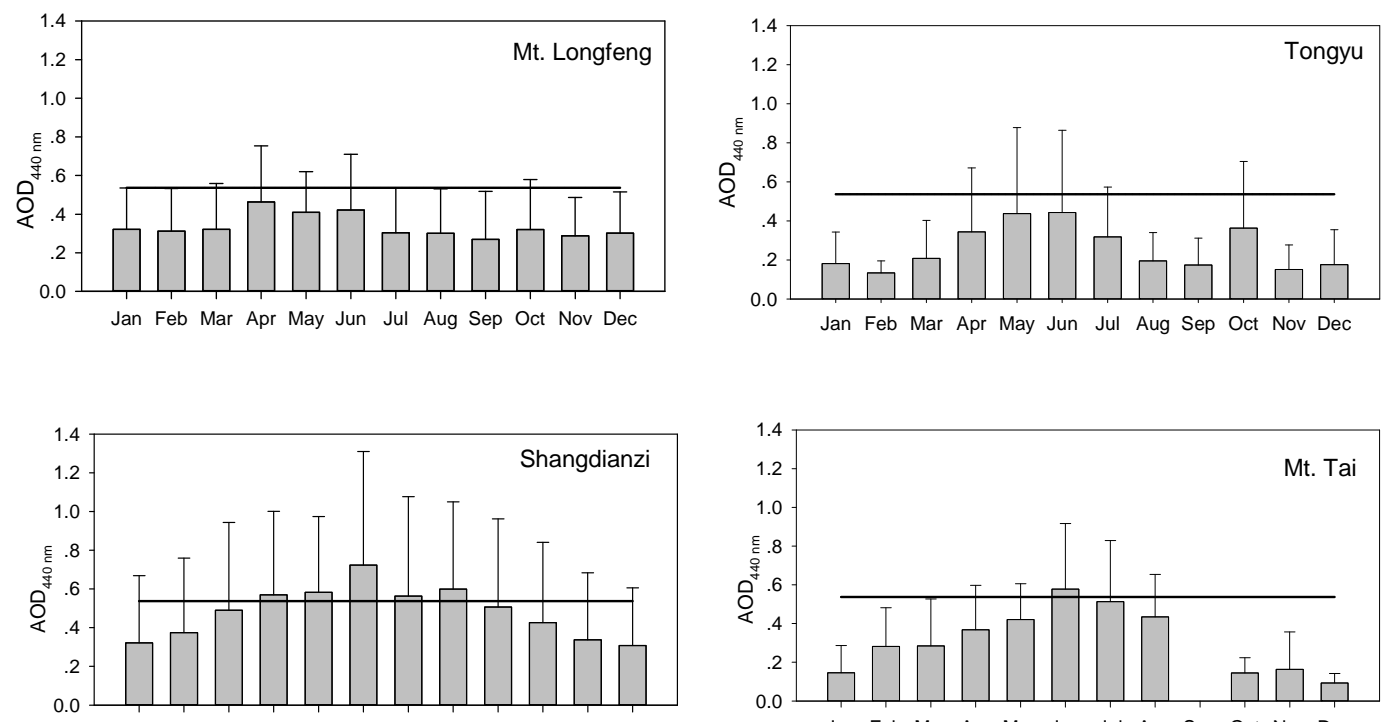

Jan Feb Mar Apr May Jun Jul Aug Sep Oct Nov Dec

Jan Feb Mar Apr May Jun Jul Aug Sep Oct Nov Dec
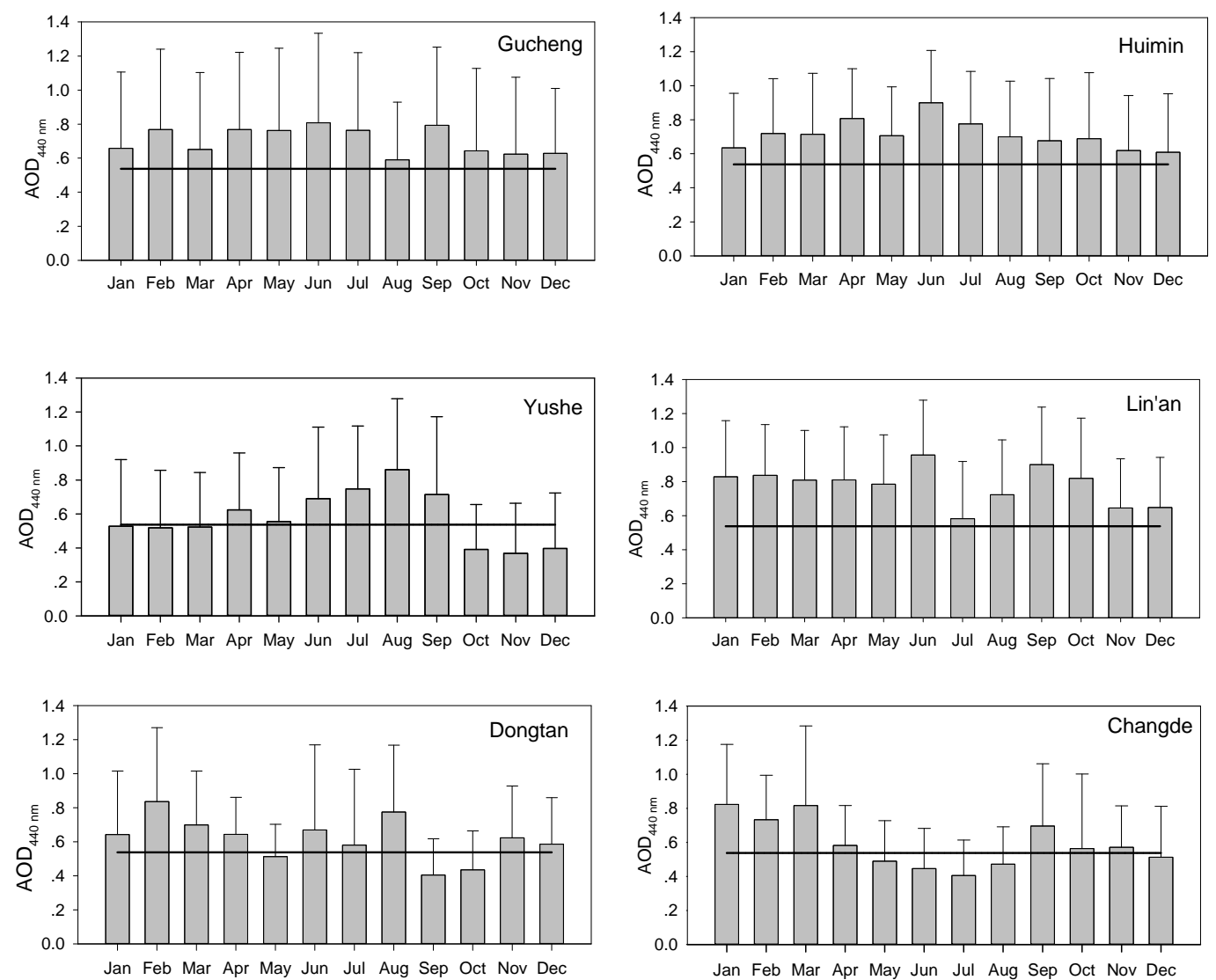

Figure 12. Monthly averaged AODs at $440 \mathrm{~nm}$ at rural central and eastern China sites. The solid and dash horizontal hairlines indicate the annual averages for the subgroup and the whole database, respectively.

Lin'an, Dontan) were quite high, most likely as a result of the burning of the straw (Logan et al., 2013b). Indeed, the AODs at Gucheng, a site surrounded by farmlands, were higher in September than in the prior month or the 2 following months; this is likely because peasants typically burn straw from agricultural fields in September. Similarly, the AODs at Tongyu were as high as 0.34 in October, and this also may have been due to the burning of biomass in nearby farmlands. 

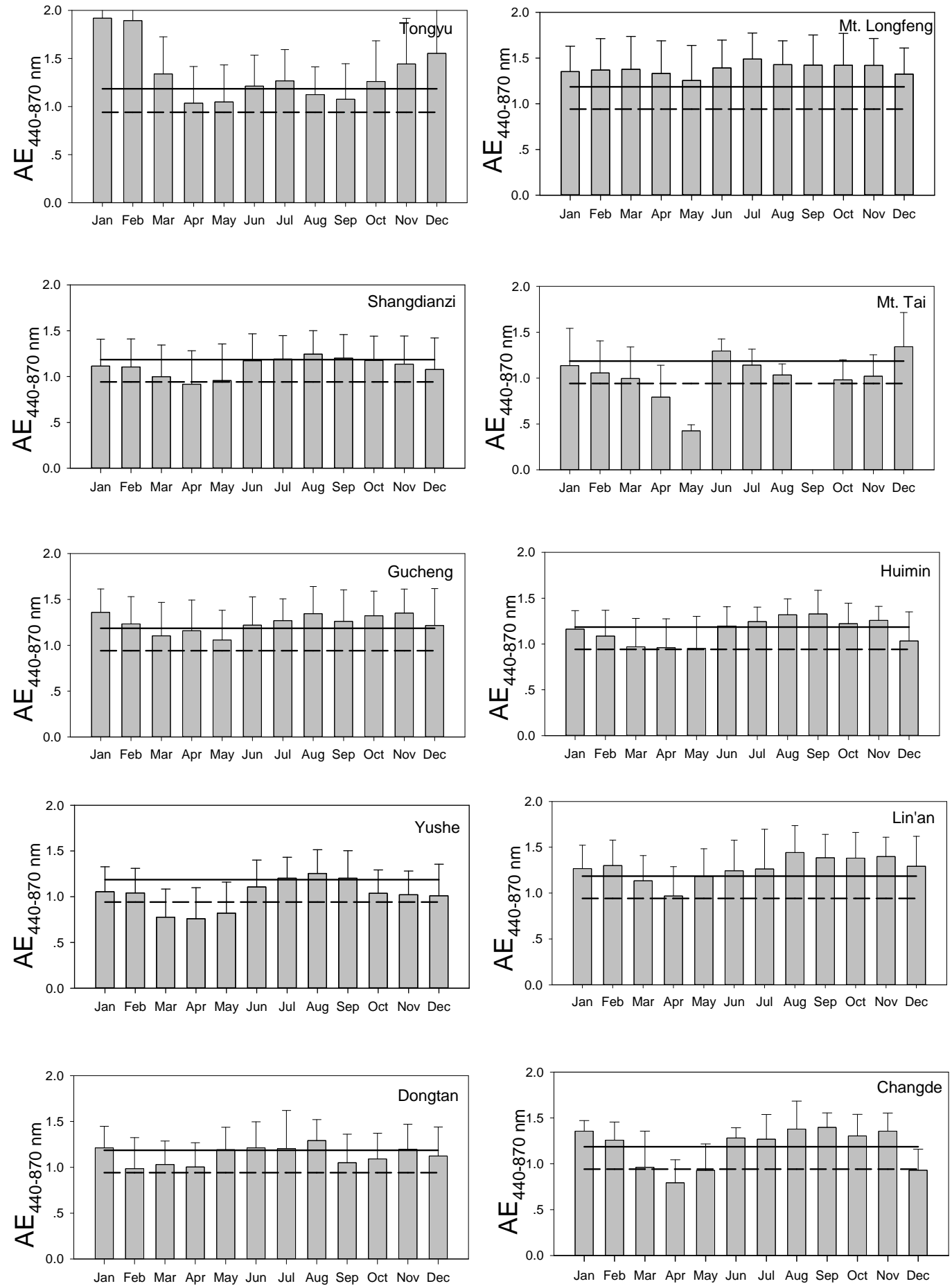

Figure 13. Monthly averaged AEs between 440 and $870 \mathrm{~nm}$ at rural central and eastern China sites. The solid and dash horizontal hairlines indicate the annual averages for the subgroup and the whole database, respectively.

Shangdianzi and Mt. Tai showed similar monthly variations in AODs: they increased from January $(0.20-0.30)$ to June $(0.60-0.70)$ and then decreased through December $(0.20-0.30)$. Gucheng and Huimin are located near farmlands, and the changes in monthly average AOD were not as obvious as at Shangdianzi and Mt. Tai where there are fewer local anthropogenic activities (Hänel et al., 2012). Nevertheless, in general, the temporal variations were similar for the four sites on the North China Plan. The AOD at Yushe was $<0.40$ from October to December, probably due to the 

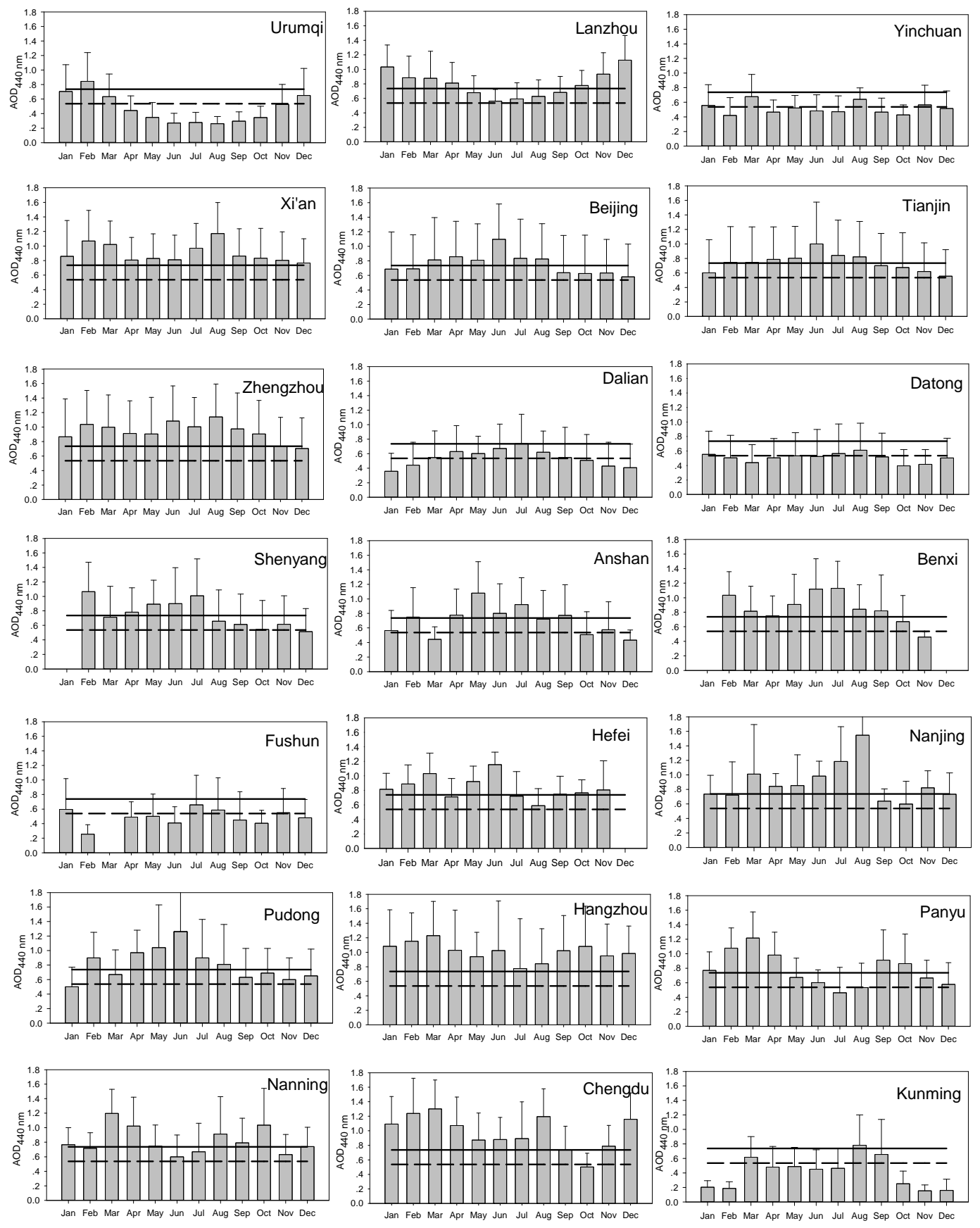

Figure 14. Monthly averaged AODs at $440 \mathrm{~nm}$ at urban sites. The solid and dash horizontal hairlines indicate the annual averages for the subgroup and the whole database, respectively.

influx of cold air in fall and winter which flushes polluted air from region. The monthly variations at Lin'an, Dongtan, and Changde, in middle and lower Yangtze River region, were different from the rural sites of northern China. The AOD of Changde was $>0.70$ from January-March and in September but $<0.60$ in the other months, and this is consistent with what has been reported for other urban areas in the middle section of the Yangtze River (Gong et al., 2014).
The AOD at Lin'an was $<0.70$ only in July and NovemberDecember; the maximum monthly average was $0.96 \pm 0.32$ in June, and the minimum $(0.58 \pm 0.34)$ was in July. At Dontan, the AODs were $<0.45$ from September to October and $\sim 0.80$ in February and August.

Figure 13 shows the monthly averaged AEs between 440 and $870 \mathrm{~nm}$ at rural central and eastern China sites of CARSNET. In general, the AEs at the rural sites in central 
and eastern China were relatively low from March to May compared with other months, and that reflects the influence of coarse particles. AE at Tongyu, Mt. Longfeng, Shangdianzi, Gucheng, Huimin, Lin'an, and Dongtan was $>0.90$ throughout the year. Three of these sites have monthly average AEs $>0.80$ from summer through winter, but in spring they are $<0.80$ at Yushe (March and April), Changde (April), and Mt. Tai (April and May). Thus, we conclude that fine mode particles were relatively abundant at the rural sites in central and eastern China, and that was most likely due to anthropogenic emissions (e.g., coal combustion, biomass burning, gas-particle conversion). The high relative abundance of fine particles was notably different from the rural sites in other regions of China, including the nearby desert and CLP sites, where there were more coarse-mode particles.

From June to September, which is the biomass burning season at the rural sites of Tongyu, Shangdianzi, Mt. Tai, Gucheng, Huimin, Lin'an, and Dongtan, the AE values were clearly larger than those in May. AE also was higher in September than in October at several other sites, including Shangdianzi Huimin, and Yushe, and this, too, is more than likely related to the emissions of fine PM from biomass burning (Zha et al., 2013).

\subsubsection{Variations in the monthly average AODs and AEs at the urban stations}

Figure 14 shows the monthly averaged AODs at $440 \mathrm{~nm}$ at urban sites of CARSNET. Of the four urban sites in northwestern China, Ürümqi and Lanzhou showed the same seasonal trends; that is, high AODs in winter and low values in summer, and this is different from the trends at the other two urban sites, Yinchuan and Xi' an. This is because large quantities of coal are burned for heating in both Ürümqi and Lanzhou in winter, and that is a major source of PM at those sites (Li et al., 2005; Quan et al., 2009). The effects of coal combustion at Ürümqi can be seen in the seasonality in the AODs - they were much higher $(>0.65)$ from December to February compared with June to September, when they were $<0.30$. The low AODs in the warmer months were not only due to the smaller amount of coal burned but also because increased precipitation and stronger convection in the warmer months reduced the PM loadings at both sites (Liu et al., 2004).

The AODs at Yinchuan varied smoothly between 0.400.70 with high monthly averaged AODs, that is $>0.60$, in March (0.67 \pm 0.30$)$ and August (0.64 \pm 0.16$)$. Xi' an was similar to Yinchuan and showed high monthly averaged AODs in February $(1.07 \pm 0.42)$ and March $(1.02 \pm 0.32)$ and also in August $(1.17 \pm 0.43)$. The seasonal patterns at Yinchuan and $\mathrm{Xi}$ ' an presumably reflect the effects of the dust storms in spring and the hygroscopic growth of particles in August due to the summertime increase in humidity (Su et al., 2014).

Of the five urban CARSNET sites located in northern China, Beijing, Tianjin and Zhengzhou showed high AODs throughout the year, and high AODs from June to August were a common characteristic at the other two sites (Dalian and Datong) as well; this reflects the hygroscopic growth of fine particles and the conversion of gases to particles over a broad area (Eck et al., 2005). At Beijing and Tianjin the AODs were greater than 0.50 with respective maximum monthly means of $1.10 \pm 0.48$ and $1.00 \pm 0.57$ in June. At Zhengzhou the monthly average AODs were $>1.00$ in February and from June to August. These very high AODs reflected the anthropogenic perturbations to the atmosphere. The combined AODs for Beijing and Tianjin, both located in Jing-Jin-Ji region of northern China, were $0.74 \pm 0.15$ in autumn and $0.72 \pm 0.12$ and winter.

Dalian, a coastal city on the Liaodong Peninsula, has experienced rapid economic development in recent decades. The AODs at Dalian showed monthly variations similar to those at Beijing and Tianjin, but the magnitude of the AODs at Dalian were substantially lower, with an annual mean $0.54 \pm 0.12$. This indicates that the particle loadings in Dalian are less than in the Chinese megacities, and one likely contributing factor is the influx of relatively clean maritime air at the coastal site. On the other hand, Dalian is an important harbor, and therefore emissions from shipping also could contribute to the aerosol loadings at this site (Zhang et al., 2015). The AODs at Dalian were high in spring, and like many of the rural sites above, this is probably due to the influx of dust in spring.

Four urban CARSNET sites, Shenyang, Anshan, Benxi, and Fushun, are located in northeastern China, a heavily industrialized region, and the AODs at these sites were as high as those at the urban sites in northern China. We also found that the AODs at the northeastern sites were high in spring and summer, especially from June to August. The AODs were typically $>0.60$ at Shenyang, Anshan, and Benxi from April to August, and this reflects the heavy aerosol loadings in this region. These results are consistent with the findings of Xia et al. (2007) who reported that the average AOD $(500 \mathrm{~nm})$ in the center of Liaoning province was $0.63 \pm 0.46$ during spring and summer. In February, the AODs we measured at Shenyang, Anshan, and Benxi were $>0.60$, and these high values were likely caused by the combustion of coal for domestic heating (Zhao et al., 2013).

There are four urban CARSNET sites (Hefei, Nanjing, Pudong, Hangzhou) in the Yangtze River Delta region, which is one of the most economically developed areas in all of China. Monthly mean AODs were generally $\geq 0.50$ at all four of these sites, indicating a regional veil of pollution, and this result is in agreement with previous observations made by Wang et al. (2012) and Xiao et al. (2011). Monthly average AODs $>1.00$ were observed from June to August, and these values are about a factor of 2 higher than the minimum monthly AODs. Furthermore, the AODs in June were higher than those in May at each of the four sites, and the high loadings were likely caused by the burning of agricultural crop residues (Cheng et al., 2014). The AOD at Pudong was lower 
than that at Hefei, Nanjing, or Hangzhou: the monthly means at Pudong were $\sim 0.70$ during September to January. These low values are more than likely because Pudong is located near the coast, and polluted air can be replaced by cleaner air from the East Sea (Pan et al., 2010).

Panyu and Nanning, two urban sites in southern China, show temporal patterns different from the Yangtze River Delta sites. AODs were high $(>0.80)$ at the two sites during two periods, first from March to April and second from September to October, and during both of these periods, biomass burning is frequent with high relative humidity (Andreae et al., 2008; Tan et al., 2009). Interestingly, the AODs were low, from 0.46-0.66, in June and July at both sites, and these were roughly half of the monthly maximum AODs, which were found in March with $\sim 1.20$ for both sites. This could be due to relative abundance of rain in the late spring and early summer and the resulting removal of PM by wet deposition as well as changes in emissions (Tan et al., 2009).

The variations in AODs at Chengdu and Kunming, two urban sites in southwestern China, differed from each other. The AODs at Chengdu were $>0.50$ throughout the year and $>1.00$ from December to April, with a maximum monthly mean of $1.30 \pm 0.40$ in March. Clearly, the aerosol loadings at Chengdu were very heavy, and this is consistent with previous measurements. Indeed, high aerosol loadings in the Sichuan Basin have been attributed to unremitting anthropogenic emissions coupled with the physical trapping of pollutants in the basin (Luo et al., 2001; Li et al., 2003; Liu et al., 2014). In comparison, the AODs at Kunming were low $(<0.30)$ from October to February, which is the dry season. High AODs $(>0.40)$ at Kunming were found from March to September, which are in the wet season when the hygroscopic growth of the particles would be expected. The AODs at both Chengdu and Kunming were high in March and $\mathrm{Au}-$ gust compared with other periods, probably due to the effects of seasonal biomass burning (Tao et al., 2013).

Figure 15 shows the monthly averaged AEs between 440 and $870 \mathrm{~nm}$ at urban sites of CARSNET. Except for Nanning and Kunming in southern China, almost all of the urban sites showed lower Ångström exponents from March to May compared with other periods, but the patterns varied somewhat among sites (Fig. 15). At the urban sites in northwest, north, and northeast China (except for Dalian and Tianjintwo coastal sites), AEs were $<0.80$ from March to April, but again there were some variations among sites. In contrast, the AEs for the sites in southern China were generally $>0.80$ during this period even though they were lower than in other months. This pattern is evidence that coarse particles, especially mineral dust, have a greater effect on the northern urban sites than the southern ones.

These coarse particles include not only natural dust transported from the deserts in northern and northwestern China but also fugitive dusts. Indeed, large quantities of fugitive dust have been produced in some urban areas as a result of increased vehicular traffic and a boom in building construction
(Fan et al., 2009). Preparations of agricultural fields for the planting of crops also cause the emission of mineral aerosol in spring, and this material can be transported to urban areas (Mei et al., 2004). From June to August, a great majority of the AEs were $>1.00$, indicating that fine mode aerosols were dominant at this time of year. Many of these fine particles were likely produced by gas-particle conversion reactions, and numerous studies have shown that the volatile organic compounds are converted into secondary organic aerosols in summer as a result of conditions favorable for photochemical reactions (Shao et al., 2009). The high humidity in summer also leads to the hydroscopic growth of fine PM (Eck et al., 2010), and these processes undoubtedly affected the AEs at some of the urban CARSNET sites.

The effects of biomass burning on the AE values for the urban CARSNET sites are not as apparent as at the rural sites in central and eastern China. Nevertheless, at some of the urban sites, including Beijing, Hefei, Nanjing, Pudong, Hangzhou, and Panyu, the AEs were high in June and from September to October; this may be related to the emissions of fine particles from biomass burning (Zhuang et al., 2011; Qi et al., 2014). However, because the aerosol sources in these urban sites are complex and not well understood, more studies are needed to investigate this possibility.

\subsection{Comparisons of urban stations with rural stations}

Rapid urbanization in parts of China has perturbed the atmosphere and caused a variety of problems, including visibility impairment and air pollution, etc. (Che et al., 2007). Among CARSNET sites, there are Beijing and Lanzhou with both urban sites and rural stations. From Figs. 12 and 14, one can see that both the AODs and the AEs at Beijing and its paired rural site Shangdianzi showed very consistent temporal variations although the AOD at Shangdianzi was of course, much lower than that at Beijing. The AE at Beijing was lower than that Shangdianzi (Figs. 13 and 15), which shows that the particles in the urban area were larger than those at the rural site. This can be explained by the greater production of fugitive dusts in the urban region (Fan et al., 2009; Zhang et al., 2013) and the settling out of larger particles during transport to the rural site. Transportation, construction activities, bare surfaces all cause the emission of fugitive dust particles in Beijing and other large cities (Chen et al., 2010). On the other hand, the surfaces Shangdianzi are more heavily vegetated, and this tends to suppress the production of PM in the area (Hänel et al., 2012).

The AODs and AEs at the urban Lanzhou site were both higher than at the rural site at Mt. Gaolan (Figs. 14 and 10 for AOD, Figs. 15 and 11 for AE), which is about $600 \mathrm{~m}$ higher than the urban site - this was true throughout the year. The AODs at Lazhou varied in the same way as at Mt. Gaolan from April to September, but they differed from October to April, and this decoupling probably results from changes in the surface boundary layer. From April to September, the 

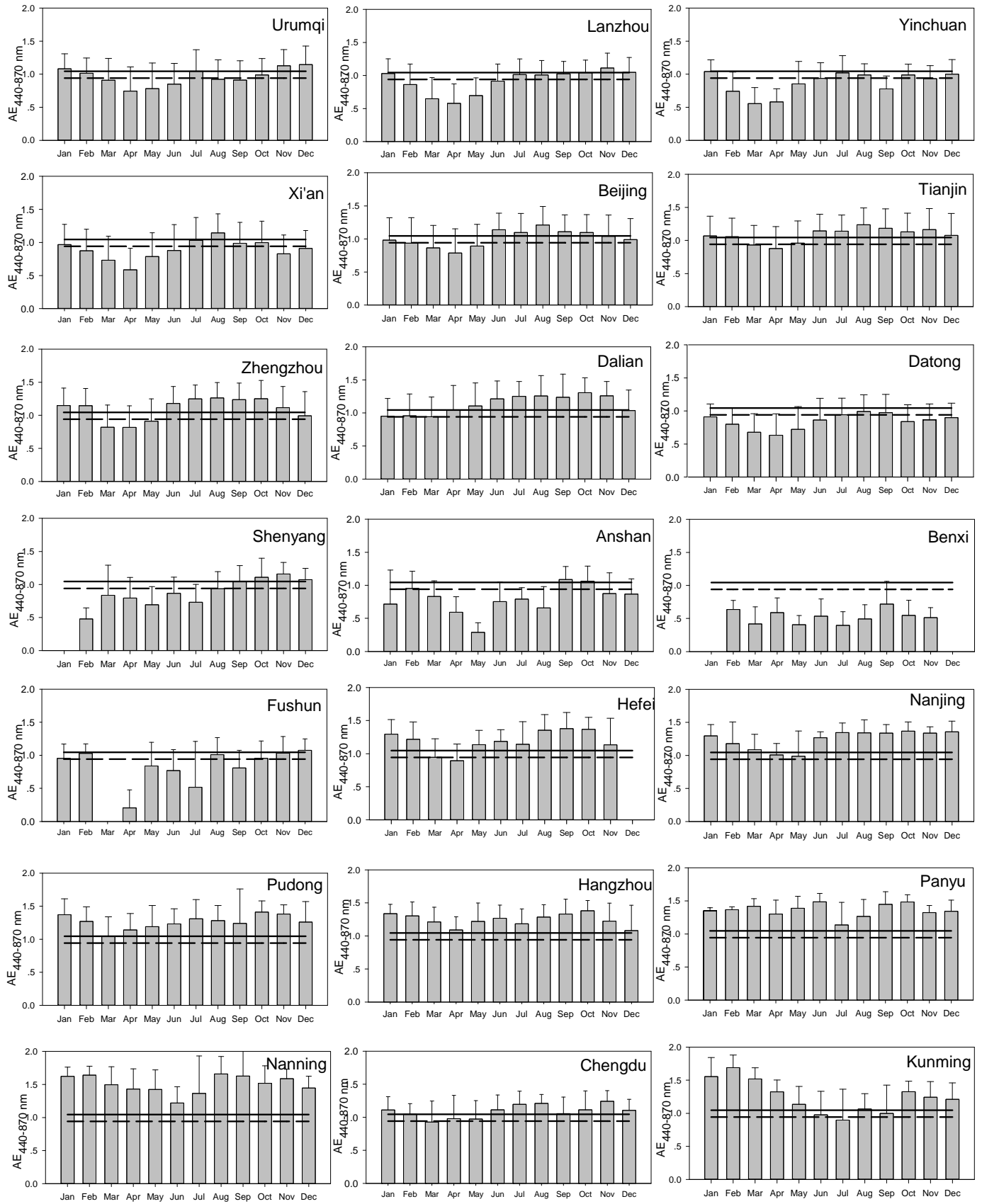

Figure 15. Monthly averaged AEs between 440 and $870 \mathrm{~nm}$ at urban sites. The solid and dash horizontal hairlines indicate the annual averages for the subgroup and the whole database, respectively.

boundary layer at both sites is normally deep, and this promotes similar variations in the aerosol populations at the two sites. From September to April, however, convection tends to be weak and the boundary layer at Lanzhou is lower than at Mt. Gaolan. The aerosol particles are then mainly concentrated in the shallower boundary layer, and that is why the AODs at the two sites become uncoupled from September to April.
In contrast to the AODs, the AE values varied coherently at Lanzhou and Mt. Gaolan (Figs. 15 and 11), and this is likely because this parameter is not concentration dependent. That is, the aerosol size variations at both sites are similar throughout the year even though the AE at Lanzhou was $>1.00$ and $<1.00$ at Mt. Gaolan. The AE values show that while the particles were mainly fine mode at both sites, they were even smaller at Lanzhou, and this difference in particle size can be explained by types of sources for the PM. Mt. Gaolan 

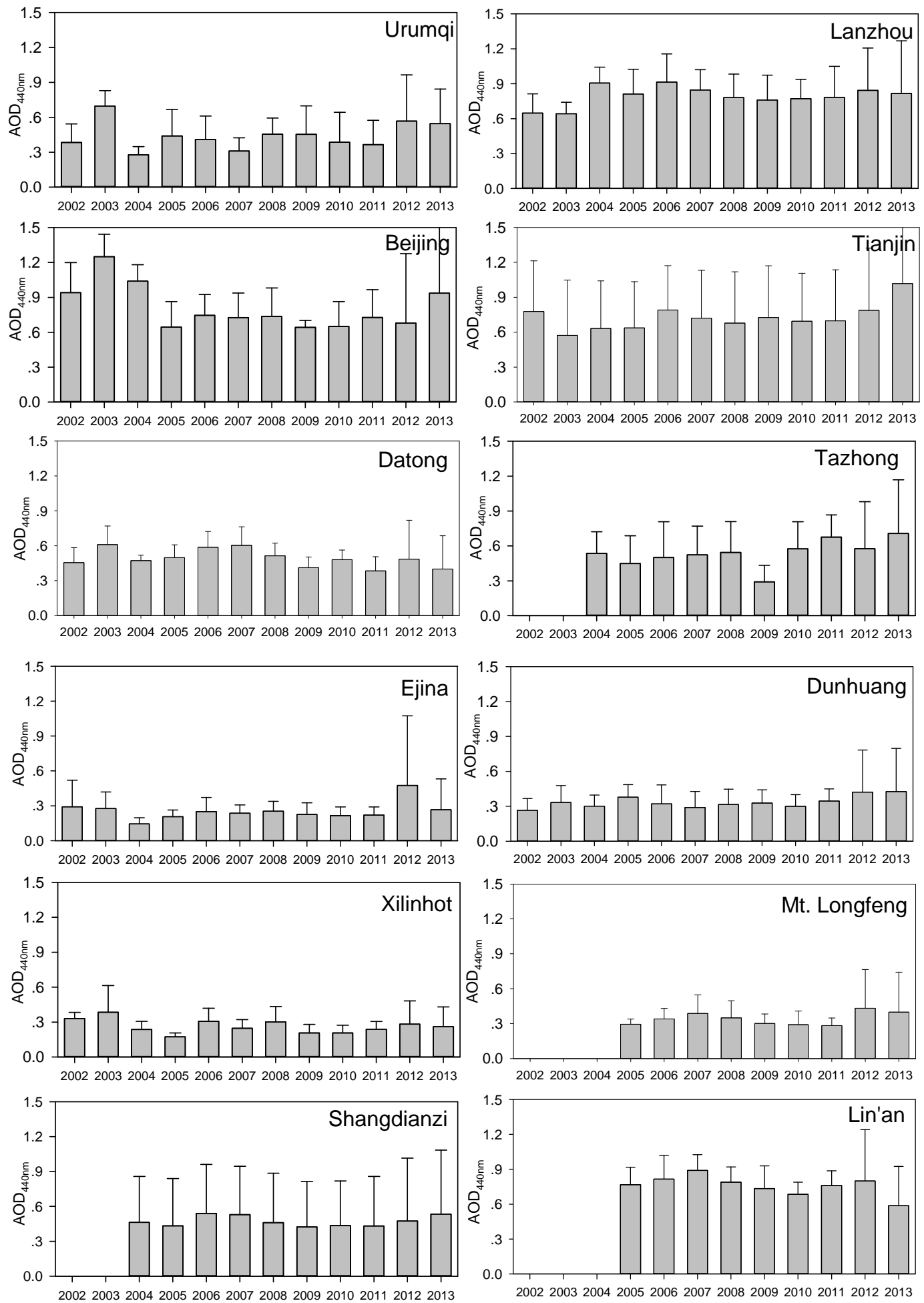

Figure 16. Annually averaged AODs at $440 \mathrm{~nm}$ for the 12 long-term CARSNET sites.

is located on the CLP where there is little vegetative cover, and large dust particles can be raised from local and regional sources. In Lanzhou, there is an abundance of anthropogenic sources for fine particles, and the production of secondary aerosol particles also contributes to fine PM and AEs $>1.00$ (Wang et al., 2010). 

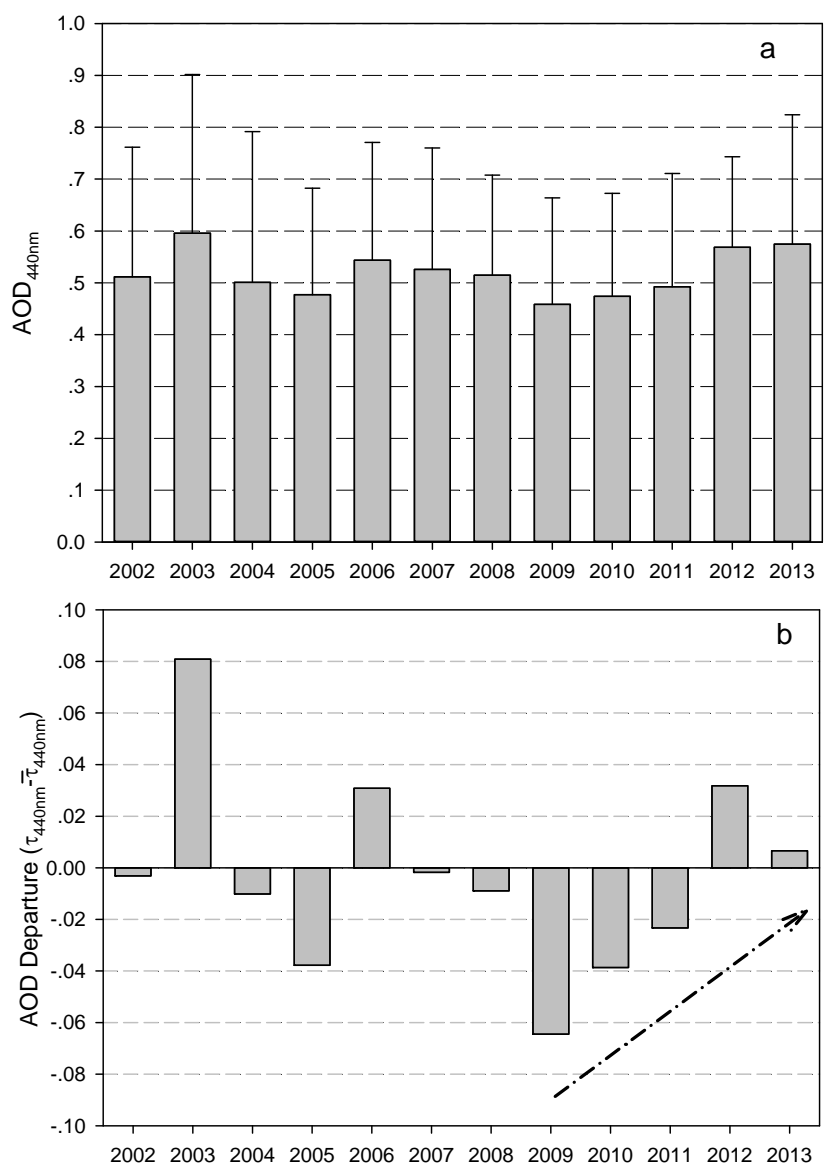

Figure 17. Temporal variations of AODs at $440 \mathrm{~nm}$ from 2002 to 2013 based on 12 long-term sites.

\subsection{Long-term variations of AODs over China}

The variations in annual AODs for the 12 CARSNET sites that were in operation for the entire study period, that is from 2002 to 2013, are shown in Fig. 16. These include five urban sites (Ürümqi, Lanzhou, Beijing, Tianjin, and Datong), four rural desert sites (Tazhong, Ejina, Dunhuang, and Xilinhot), and three regional background sites (Mt. Longfeng, Shangdianzi, and Lin'an), and as a group, they can be considered a reasonable representation of how conditions have changed in China. As shown in Fig. 16, most of these sites showed overall decreases in AODs from 2006 to 2011; the one exception was Tazhong, which is in the central of the Taklimakan Desert. The decrease was not continuous, however as the AODs apparently increased from 2012 at some sites, including Ürümqi, Ejina, Dunhuang, Tianjin, Beijing, Mt. Longfeng, and Shangdianzi.

The composited average AODs for these 12 sites was highest in 2003, and there was a slight decrease from 2006 to 2009 followed by an increase from 2009 to 2013 (Fig. 17a). From Fig. 17b, which shows the departure of the AODs from the average, we can see that AODs in 2003, 2006, and 2012 were $0.03-0.08$ larger than the 12 year average. Moreover, the composite AOD increased $\sim 0.03$ from 2009 to 2013, and this suggests that aerosol loadings in China may have increased in recent years. Identifying the reasons for any increase in aerosol loading would be critically important of course, and one obvious possibility is that there has been an increase in emissions (Streets et al., 2001; Lei et al., 2011).

Increasing aerosol emissions obviously would tend to increase the AODs over most of China, but another possible reason for the trends in AODs is changes in the physical environment, especially the intensity of the East Asian monsoon. Recently, Pal and Devara (2012) found that both the urbanization and the monsoon could influence the variability of the aerosol burden obviously in India. In fact, aerosol loads over China are also strongly influenced by the Asian monsoonal flow and the associated precipitation (Yoon et al., 2010). There is also some evidence that the numbers of windy days and the wind speeds in China have decreased in recent decades (Jiang et al., 2010; Fu et al., 2011), and both of these changes would favor the buildup of anthropogenic emissions in the near-surface air sampled for CARSNET. Indeed, recent studies have shown that a weakening of the monsoonal circulation in recent decades may have led to an increase in aerosol loadings over many parts of China (Liu et al., 2011; Chin, 2012; Zhu et al., 2012). As an example of this, 2003 was regarded as a "weak" year in terms of the Asian monsoon. The composite AOD for the 12 CARSNET sites for that year showed a departure from the average of about +0.08 , and this could reflect the weakness of the monsoon, and therefore, changes in climate also affect the ambient aerosol.

While strong winds can dissipate anthropogenic aerosols in eastern China region, they also can transport mineral dust from desert regions in northern and northwestern China. Figure 16 shows that the rural desert sites such as Ejina, Dunhuang, Xilinhot in northwestern and northern China had larger AODs in 2006 compared with 2007, and this may be related to the stronger winds and hence greater production of dust in 2006. However, much of the preceding discussion is still speculative, and more studies and observations will be needed to test these ideas in the future.

\section{Summary and conclusions}

In this study, data collected from the CARSNET network from 2002 to 2013 were used to characterize the aerosol optical properties over a large area of China. The AODs at $440 \mathrm{~nm}$ generally increased from north to south, and very low AODs $(<0.20)$ were found only in remote regions, including the Tibetan Plateau and parts of northwestern China. Large AODs ( $>0.60)$ mainly occurred in central and eastern China where heavy industrial and other anthropogenic emissions led to high aerosol loadings. AOD levels of 0.20 0.40 were observed in semi-arid and arid regions as well as at 
some regional background areas in northern and northeastern China.

Large AEs between 440 and $870 \mathrm{~nm}$ (> 1.20), which are caused by large proportions of fine particles, were observed at the sites in the southern reaches of the Yangtze River and at the clean sites in northeastern China. In the desert regions of northwest China and industrial region of northeastern China, the $\mathrm{AE}$ values were significantly lower $(<0.80)$ compared with those in the central and eastern regions, such as the North China Plain, Guanzhong Plain, or Sichuan Basin.

For most sites in northern China, the aerosol columnar extinctions were larger in spring and summer than in fall and winter. About half of the sites had AE $<0.60$ in spring, and this was due to large dust particles transported from semiarid and arid regions in northwestern and northern China. AE $>0.80$ also occurred in the central and east China regions from summer to winter and in south China all year round, suggesting that fine-mode particles were the main components of the aerosol populations in those areas.

The AODs at the remote sites ranged from 0.11 to 0.18 , and averaged $0.14 \pm 0.04$ while the Ångström exponents at those sites varied from $0.59-1.29$ with an average of $0.97 \pm$ 0.29 . In comparison, the AODs at rural desert stations varied from 0.23 to 0.61 (average $0.34 \pm 0.12$ ). The AODs and AEs at the rural stations on the Loess Plateau were 0.37 to 0.46 and 0.79 to 0.89 , respectively and the corresponding means were $0.42 \pm 0.05$ and $0.82 \pm 0.05$. The AODs at rural sites in central and eastern China showed the much higher AODs compared with the rural sites close to deserts or located on the CLP. The average AOD at rural sites of East China was $0.54 \pm 0.18$ while the average AE was $1.19 \pm 0.12$. The AODs at this region varied over a large range, from 0.26 to 0.78 , and the AEs at all of these sites were larger than 1.00, ranging from 1.02 to 1.38 , and suggesting the dominance of fine particles.

The monthly average AODs at the urban stations ranged from 0.40 to 1.00 with an average of $0.74 \pm 0.18$, and the range for the AEs was 0.52-1.50 with average 1.05 \pm 0.23 ; these large AEs indicate that the aerosols were predominately fine mode. The AODs were lower in remote, rural, and urban sites in fall and winter compared with spring and summer. However, the AEs in fall and winter were larger than in the spring and summer seasons.

Monthly averaged AODs and AEs show different patterns at the remote, rural and urban sites, and this reflects the spatial and temporal heterogeneity of the aerosol. The most important factors driving the temporal variations in aerosol optical properties are the natural dust events and anthropogenic activities. In eastern China, the aerosol optical properties are affected by both natural and anthropogenic mineral dust from March to May, and burning of biomass and the formation of second aerosol particles contribute to the high AODs from June through October at most rural and urban sites. The aerosol optical properties in winter season are strongly af- fected by the burning of coal for heating, especially in northern China.

A comparison of AODs and AEs between pairs of urban and rural stations in Beijing and Lanzhou showed that seasonal variations in the vertical distribution of the aerosol cause changes significant in the aerosol optical properties. A comparison of the data for the Lanzhou-Mt. Gaolan paired sites indicated that the depth of the boundary was an important determinant of the seasonal variations of PM with height.

The annual variations in the AODs at the 12 CARSNET long-term (2002 to 2013) observation sites show a decreasing trend from 2006 to 2009 but an increase of $\sim 0.03$ from 2009 to 2013 . This suggests the possibility that the aerosol loadings in China have reversed a decreasing trend and increased in recent years. However, the year-to-year variability in AODs is affected by changes in the strength of the East Asian monsoon as well as variations in emissions, and the interpretation of long-term records of aerosol optical properties needs to take both of these factors - and possibly others - into account.

Although this work is based on the longest and most extensive set of ground-based observations of aerosol optical properties made in China to date, it is just a first step towards understanding what controls the aerosol populations. More detailed work is needed in the future, and we have developed a set of recommendations for continued monitoring efforts. First, CARSNET should continue collaborating with other international networks, including AERONET, PHOTONS, RIMA, SKYNET, etc. to ensure consistency in calibration protocols as well as cloud-screening and data retrieval processing procedures. Second, the network should be expanded and the studies extended in time to obtain more detailed information on the aerosol optical properties over China. Instrument and site maintenance should be top priorities as these efforts would improve data quality and minimize gaps in the data. Third, in addition to AOD and AE, other key parameters such as single scattering albedo, size distributions and the optical properties of fine mode particles should be measured. The results of our current project are potentially valuable for inter-comparisons with measurements made with satellites as well as for assimilation into and validation of aerosol models. Furthermore, the results are not only relevant for China but also for East Asia, and therefore, the data used to prepare the figures for this paper have been made available as an Appendix. 


\section{Appendix A}

Table A1. Site information for the 50 CARSNET sites used in this study.

\begin{tabular}{rlrrrl}
\hline No. & Site Name & Long. & Lat. & Alt. & Site information \\
\hline Remote sites (4 sites) & & & & & Obs. days \\
\hline 1 & Akedala & 47.12 & 87.97 & 562.0 & $\begin{array}{l}55 \mathrm{~km} \text { west of Fuhai county, Xinjiang province, and 250-300 km } \\
\text { southeast of Kazakhstan. }\end{array}$ \\
2 & Lhasa & 29.67 & 91.13 & 3663.0 & $\begin{array}{l}\text { In the center of Lhasa city, Tibetan Plateau. } \\
\text { On the east edge of Qinghai-Xizang Plateau, Qinghai province, } \\
3\end{array}$ Mt. Waliguan \\
36.28 & 100.92 & 3810.0 & $\begin{array}{l}\text { Global GAW station } \\
12 \mathrm{~km} \text { northeast of Shangri-La county (Diqing area, Yunnan province, } \\
\text { China) }\end{array}$
\end{tabular}

\begin{tabular}{|c|c|c|c|c|c|c|}
\hline \multicolumn{7}{|c|}{ Rural sites near the northern and northwestern deserts of China (11 sites) } \\
\hline 5 & Dunhuang & 40.15 & 94.68 & 1139.0 & $\begin{array}{l}1.5 \mathrm{~km} \text { northeast of Dunhuang city, Gansu province; near the Kumu- } \\
\text { tage Desert of China }\end{array}$ & 2370 \\
\hline 6 & Ejina & 41.95 & 101.07 & 940.5 & $\begin{array}{l}\text { West of Inner Mongolia province, near Mongolia and the Badanjilin } \\
\text { Desert }\end{array}$ & 2250 \\
\hline 7 & Hami & 42.82 & 93.52 & 737.0 & $\begin{array}{l}500 \mathrm{~km} \text { east of Ürümqi, in Hami county, nearby the Gobi Desert, Xin- } \\
\text { jiang province }\end{array}$ & 685 \\
\hline 8 & Hotan & 37.13 & 79.93 & 1374.7 & $\begin{array}{l}\text { South edge of the Taklimakan Desert, } 1000 \mathrm{~km} \text { south from Ürümqi, } \\
\text { Xinjiang province }\end{array}$ & 612 \\
\hline 9 & Jiuquan & 39.77 & 98.48 & 1477.3 & $\begin{array}{l}5 \mathrm{~km} \text { north of Jiuquan city, Gansu province, nearby the Badanjilin } \\
\text { Desert }\end{array}$ & 412 \\
\hline 10 & Minqin & 38.63 & 103.08 & 1367.0 & $\begin{array}{l}\text { In Minqin county, east of the Tenggeli Desert and north of the Badan- } \\
\text { jilin Desert, Gansu province }\end{array}$ & 1435 \\
\hline 11 & Tazhong & 39.00 & 83.67 & 1099.4 & In the middle of Taklimakan Desert, Xinjiang province & 1984 \\
\hline 12 & Ulate & 41.57 & 108.52 & 1288.0 & Northwest of Inner Mongolia, but in grass desertification region & 712 \\
\hline 13 & Xilinhot & 43.95 & 116.12 & 1003.0 & $\begin{array}{l}5 \mathrm{~km} \text { southeast of Xilinhot city, Inner Mongolia province, and near } \\
\text { Hunshandake sand land }\end{array}$ & 2228 \\
\hline 14 & Zhangbei & 41.15 & 114.70 & 1093.4 & $\begin{array}{l}40 \mathrm{~km} \text { north of Zhangjiakou city Hebei province, and near Hunshan- } \\
\text { dake sand land }\end{array}$ & 219 \\
\hline 15 & Zhurihe & 42.40 & 112.90 & 1152.0 & $\begin{array}{l}\text { In the middle of Inner Mongolia province, and nearby Hunshandake } \\
\text { sand land }\end{array}$ & 365 \\
\hline
\end{tabular}

\begin{tabular}{|c|c|c|c|c|c|c|}
\hline \multicolumn{7}{|c|}{ Rural sites on or near the Chinese Loess Plateau (4 sites) } \\
\hline 16 & Dongsheng & 39.83 & 109.98 & 1460.5 & In the center of Ordos city, Inner Mongolia province & 234 \\
\hline 17 & Mt. Gaolan & 36.00 & 103.85 & 2161.6 & $5 \mathrm{~km}$ north from Lanzhou city, Gansu province. & 766 \\
\hline 18 & Yan'an & 36.60 & 109.50 & 958.5 & $2 \mathrm{~km}$ northeast of Yan'an city, Shaanxi province & 218 \\
\hline 19 & Yulin & 38.43 & 109.20 & 1135.0 & $10 \mathrm{~km}$ north of Yulin city, Shaanxi province & 451 \\
\hline \multicolumn{7}{|c|}{ Rural sites in eastern China (10 sites) } \\
\hline 20 & Changde & 29.17 & 111.70 & 565.0 & $18 \mathrm{~km}$ northwest from Changde city, Hunan province & 210 \\
\hline 21 & Dongtan & 31.52 & 121.96 & 10.0 & In the Chongming Island, $30 \mathrm{~km}$ east of Shanghai city & 374 \\
\hline 22 & Gucheng & 39.13 & 115.80 & 45.2 & $\begin{array}{l}\text { Within area of rapid urbanization, } 38 \mathrm{~km} \text { southwest of Baoding city, } \\
\text { Hebei province. }\end{array}$ & 750 \\
\hline 23 & Huimin & 37.48 & 117.53 & 11.7 & $100 \mathrm{~km}$ Northeast of Jin' an city, Shandong province & 851 \\
\hline 24 & Lin'an & 30.30 & 119.73 & 138.6 & $\begin{array}{l}150 \mathrm{~km} \text { northeast of Shanghai, and } 50 \mathrm{~km} \text { west of Hangzhou city, Zhe- } \\
\text { jiang province }\end{array}$ & 1029 \\
\hline 25 & Mt. Longfeng & 44.73 & 127.60 & 330.5 & $\begin{array}{l}\text { In Wuchang county, } 175 \mathrm{~km} \text { northeast of Harbin city, Heilongjiang } \\
\text { province }\end{array}$ & 1357 \\
\hline 26 & Mt. Tai & 36.25 & 117.10 & 1591.0 & $\begin{array}{l}\text { At the summit of Mt. Tai, middle of North China Plain, Shandong } \\
\text { province }\end{array}$ & 173 \\
\hline 27 & Shangdianzi & 40.65 & 117.12 & 293.0 & In Miyun county, $150 \mathrm{~km}$ northeast of Beijing city & 2042 \\
\hline 28 & Tongyu & 44.42 & 122.87 & 151.0 & In Tongyu county, west of Jilin province & 738 \\
\hline 29 & Yushe & 37.07 & 112.98 & 1041.5 & $1.5 \mathrm{~km}$ east of Yushe county, Shanxi province & 1045 \\
\hline
\end{tabular}


Table A1. Continued.

\begin{tabular}{|c|c|c|c|c|c|c|}
\hline No. & Site Name & Long. & Lat. & Alt. & Site information & Obs. days \\
\hline \multicolumn{7}{|c|}{ Urban sites (21 sites) } \\
\hline 30 & Anshan & 41.08 & 123.00 & 23.0 & In the center of Anshan city, Liaoning province. & 230 \\
\hline 31 & Beijing & 39.80 & 116.47 & 31.3 & In the southeast of Beijing's center at the city margin & 1594 \\
\hline 32 & Benxi & 41.32 & 123.78 & 183.0 & In the center of Benxi city, Liaoning province. & 376 \\
\hline 33 & Chengdu & 30.65 & 104.03 & 496.0 & In the center of Chengdu city, Sichuan province. & 212 \\
\hline 34 & Dalian & 38.90 & 121.63 & 91.5 & Southeast of Dalian center at the city margin, Liaoning province & 763 \\
\hline 35 & Datong & 40.10 & 113.33 & 1067.3 & $\begin{array}{l}9 \mathrm{~km} \text { of Datong city, but within an area of rapid urbanization, Shanxi } \\
\text { province }\end{array}$ & 2269 \\
\hline 36 & Fushu & 41.88 & 123.95 & 80.0 & In the center of Fushun city, Liaoning province. & 242 \\
\hline 37 & Hangzhou & 30.23 & 120.17 & 42.0 & In the center of Hangzhou city, Zhengjiang province. & 365 \\
\hline 38 & Hefei & 31.98 & 116.38 & 92.0 & In the center of Hefei city, Anhui province. & 293 \\
\hline 39 & Kunming & 25.01 & 102.65 & 1889.0 & In the west region of Kunming city, Yunnan province & 301 \\
\hline 40 & Lanzhou & 36.05 & 103.88 & 1517.3 & In the center of Lanzhou city, Gansu province. & 2157 \\
\hline 41 & Nanjing & 32.05 & 118.77 & 99.3 & In the center of Nanjing city, Jiangsu province & 128 \\
\hline 42 & Nanning & 22.82 & 108.35 & 172.0 & In Nanning city, Guangxi province & 390 \\
\hline 43 & Panyu & 23 & 113.35 & 145.0 & In Panyu district of Guangzhou city, Guangdong province & 142 \\
\hline 44 & Pudong & 31.22 & 121.55 & 14.0 & In Pudong district of Shanghai city & 317 \\
\hline 45 & Shenyang & 41.77 & 123.50 & 60.0 & In the center of Shenyang city, Liaoning province. & 477 \\
\hline 46 & Tianjin & 39.10 & 117.17 & 3.3 & In the center of Tianjin city. & 1452 \\
\hline 47 & Ürümqi & 43.78 & 87.62 & 935.0 & In the center of Ürümqi city, Xijiang province & 1624 \\
\hline 48 & Xi'an & 34.43 & 108.97 & 363.0 & $\begin{array}{l}20 \mathrm{~km} \text { north of center of Xi' an city, but within Jing River industrial } \\
\text { district, Shaanxi province }\end{array}$ & 569 \\
\hline 49 & Yinchuan & 38.48 & 106.22 & 1111.5 & In the center of Yinchuan city, Ningxia province & 273 \\
\hline 50 & Zhengzhou & 34.78 & 113.68 & 99.0 & In the center of Zhengzhou city, Henan province & 915 \\
\hline
\end{tabular}


Table A2. Data for Figs. 2-3.

\begin{tabular}{|c|c|c|c|c|c|c|c|c|c|c|c|}
\hline \multirow[t]{2}{*}{ No. } & \multirow[t]{2}{*}{ Name } & \multicolumn{5}{|c|}{ AOD at $440 \mathrm{~nm}$} & \multicolumn{5}{|c|}{$\mathrm{AE}$ between 440 and $870 \mathrm{~nm}$} \\
\hline & & Annual & Spring & Summer & Fall & Winter & Annual & Spring & Summer & Fall & Winter \\
\hline 1 & Akedala & 0.20 & 0.21 & 0.23 & 0.15 & 0.22 & 1.13 & 0.92 & 1.12 & 1.13 & 1.33 \\
\hline 2 & Anshan & 0.70 & 0.77 & 0.82 & 0.62 & 0.58 & 0.79 & 0.83 & 0.85 & 0.96 & 0.96 \\
\hline 3 & Beijing & 0.76 & 0.83 & 0.92 & 0.63 & 0.65 & 1.01 & 0.85 & 1.15 & 1.08 & 0.97 \\
\hline 4 & Benxi & 0.85 & 0.82 & 1.03 & 0.65 & 1.03 & 0.52 & 0.62 & 0.61 & 0.76 & 0.59 \\
\hline 5 & Changde & 0.59 & 0.63 & 0.44 & 0.61 & 0.69 & 1.18 & 0.89 & 1.31 & 1.35 & 1.18 \\
\hline 6 & Chengdu & 0.98 & 1.08 & 0.99 & 0.68 & 1.16 & 1.09 & 0.96 & 1.17 & 1.14 & 1.09 \\
\hline 7 & Dalian & 0.54 & 0.64 & 0.68 & 0.50 & 0.40 & 1.13 & 1.12 & 1.24 & 1.27 & 0.98 \\
\hline 8 & Datong & 0.51 & 0.49 & 0.57 & 0.44 & 0.52 & 0.84 & 0.68 & 0.93 & 0.89 & 0.87 \\
\hline 9 & Dongsheng & 0.46 & 0.50 & 0.61 & 0.38 & 0.34 & 0.79 & 0.56 & 1.03 & 0.78 & 0.79 \\
\hline 10 & Dongtan & 0.62 & 0.62 & 0.67 & 0.49 & 0.69 & 1.13 & 1.08 & 1.24 & 1.11 & 1.11 \\
\hline 11 & Dunhuang & 0.32 & 0.48 & 0.32 & 0.21 & 0.28 & 0.46 & 0.29 & 0.40 & 0.55 & 0.59 \\
\hline 12 & Ejina & 0.25 & 0.36 & 0.27 & 0.18 & 0.18 & 0.57 & 0.37 & 0.56 & 0.68 & 0.67 \\
\hline 13 & Fushu & 0.49 & 0.49 & 0.55 & 0.47 & 0.44 & 0.84 & 0.85 & 0.93 & 0.94 & 0.94 \\
\hline 14 & Gucheng & 0.70 & 0.73 & 0.72 & 0.69 & 0.68 & 1.24 & 1.11 & 1.28 & 1.31 & 1.27 \\
\hline 15 & Hami & 0.25 & 0.31 & 0.24 & 0.20 & 0.26 & 0.62 & 0.54 & 0.71 & 0.57 & 0.66 \\
\hline 16 & Hangzhou & 1.01 & 1.07 & 0.88 & 1.02 & 1.07 & 1.24 & 1.17 & 1.24 & 1.31 & 1.24 \\
\hline 17 & Hefei & 0.83 & 0.89 & 0.82 & 0.77 & 0.85 & 1.19 & 0.99 & 1.23 & 1.29 & 1.26 \\
\hline 18 & Hotan & 0.61 & 0.75 & 0.75 & 0.37 & 0.51 & 0.22 & 0.09 & 0.10 & 0.30 & 0.48 \\
\hline 19 & Huimin & 0.71 & 0.74 & 0.79 & 0.66 & 0.65 & 1.14 & 0.96 & 1.25 & 1.27 & 1.09 \\
\hline 20 & Jiuquan & 0.31 & 0.43 & 0.29 & 0.21 & 0.30 & 0.50 & 0.39 & 0.48 & 0.49 & 0.65 \\
\hline 21 & Kunming & 0.41 & 0.53 & 0.57 & 0.35 & 0.18 & 1.24 & 1.33 & 0.98 & 1.19 & 1.48 \\
\hline 22 & Lanzhou & 0.80 & 0.79 & 0.59 & 0.80 & 1.01 & 0.92 & 0.64 & 0.98 & 1.06 & 0.98 \\
\hline 23 & Lhasa & 0.11 & 0.16 & 0.12 & 0.09 & 0.09 & 0.89 & 0.67 & 1.01 & 1.10 & 0.78 \\
\hline 24 & Lin'an & 0.78 & 0.80 & 0.75 & 0.79 & 0.77 & 1.27 & 1.10 & 1.32 & 1.39 & 1.29 \\
\hline 25 & Minqin & 0.39 & 0.46 & 0.44 & 0.35 & 0.29 & 0.54 & 0.37 & 0.51 & 0.58 & 0.68 \\
\hline 26 & Mt. Gaolan & 0.46 & 0.55 & 0.41 & 0.43 & 0.46 & 0.78 & 0.59 & 0.86 & 0.85 & 0.83 \\
\hline 27 & Mt. Longfeng & 0.34 & 0.40 & 0.34 & 0.29 & 0.31 & 1.38 & 1.32 & 1.44 & 1.42 & 1.35 \\
\hline 28 & Mt. Tai & 0.33 & 0.36 & 0.51 & 0.29 & 0.17 & 1.05 & 0.74 & 1.16 & 1.14 & 1.18 \\
\hline 29 & Mt. Waliguan & 0.14 & 0.21 & 0.17 & 0.09 & 0.09 & 0.59 & 0.34 & 0.75 & 0.72 & 0.54 \\
\hline 30 & Nanjing & 0.89 & 0.90 & 1.24 & 0.69 & 0.73 & 1.24 & 1.03 & 1.32 & 1.35 & 1.28 \\
\hline 31 & Nanning & 0.82 & 0.99 & 0.73 & 0.82 & 0.74 & 1.50 & 1.45 & 1.41 & 1.58 & 1.57 \\
\hline 32 & Panyu & 0.78 & 0.96 & 0.53 & 0.81 & 0.81 & 1.36 & 1.37 & 1.30 & 1.42 & 1.35 \\
\hline 33 & Pudong & 0.80 & 0.89 & 0.99 & 0.64 & 0.68 & 1.26 & 1.12 & 1.27 & 1.34 & 1.30 \\
\hline 34 & Shangdianzi & 0.48 & 0.55 & 0.63 & 0.42 & 0.33 & 1.11 & 0.96 & 1.20 & 1.17 & 1.10 \\
\hline 35 & Shangri-La & 0.11 & 0.13 & 0.15 & 0.09 & 0.06 & 1.26 & 1.16 & 1.28 & 1.39 & 1.19 \\
\hline 36 & Shenyang & 0.76 & 0.80 & 0.86 & 0.59 & 0.79 & 0.88 & 0.90 & 0.98 & 1.05 & 0.84 \\
\hline 37 & Tazhong & 0.54 & 0.81 & 0.66 & 0.34 & 0.33 & 0.29 & 0.10 & 0.15 & 0.38 & 0.51 \\
\hline 38 & Tianjin & 0.74 & 0.78 & 0.89 & 0.67 & 0.64 & 1.08 & 0.92 & 1.17 & 1.16 & 1.07 \\
\hline 39 & Tongyu & 0.26 & 0.33 & 0.32 & 0.23 & 0.16 & 1.35 & 1.14 & 1.20 & 1.26 & 1.79 \\
\hline 40 & Ulate & 0.28 & 0.34 & 0.36 & 0.21 & 0.23 & 0.75 & 0.64 & 0.86 & 0.73 & 0.77 \\
\hline 41 & Ürümqi & 0.47 & 0.48 & 0.27 & 0.39 & 0.73 & 0.96 & 0.81 & 0.94 & 1.01 & 1.08 \\
\hline 42 & Xi'an & 0.90 & 0.89 & 0.98 & 0.83 & 0.90 & 0.89 & 0.70 & 1.02 & 0.94 & 0.92 \\
\hline 43 & Xilinhot & 0.26 & 0.32 & 0.33 & 0.19 & 0.19 & 0.79 & 0.75 & 0.88 & 0.79 & 0.75 \\
\hline 44 & Yanan & 0.37 & 0.38 & 0.41 & 0.37 & 0.34 & 0.89 & 0.63 & 1.01 & 1.04 & 0.87 \\
\hline 45 & Yinchuan & 0.52 & 0.56 & 0.53 & 0.49 & 0.50 & 0.87 & 0.66 & 0.98 & 0.90 & 0.93 \\
\hline 46 & Yulin & 0.38 & 0.41 & 0.50 & 0.27 & 0.34 & 0.82 & 0.60 & 0.93 & 0.96 & 0.79 \\
\hline 47 & Yushe & 0.58 & 0.57 & 0.77 & 0.49 & 0.48 & 1.02 & 0.79 & 1.19 & 1.09 & 1.04 \\
\hline 48 & Zhangbei & 0.30 & 0.33 & 0.36 & 0.30 & 0.24 & 0.56 & 0.50 & 0.64 & 0.58 & 0.52 \\
\hline 49 & Zhengzhou & 0.94 & 0.94 & 1.08 & 0.87 & 0.87 & 1.10 & 0.85 & 1.23 & 1.20 & 1.10 \\
\hline 50 & Zhurihe & 0.24 & 0.29 & 0.36 & 0.18 & 0.14 & 0.80 & 0.57 & 0.83 & 0.80 & 1.01 \\
\hline
\end{tabular}


Table A3. Data of Figs. 6-15: AOD at $440 \mathrm{~nm}$.

\begin{tabular}{|c|c|c|c|c|c|c|c|c|c|c|c|c|c|c|}
\hline & Site & AOD & Jan & Feb & Mar & Apr & May & Jun & Jul & Aug & Sep & Oct & Nov & Dec \\
\hline \multirow{2}{*}{1} & \multirow{2}{*}{ Akedala } & Mean & 0.16 & 0.28 & 0.24 & 0.21 & 0.17 & 0.20 & 0.33 & 0.15 & 0.16 & 0.12 & 0.16 & 0.20 \\
\hline & & Stdev & 0.15 & 0.19 & 0.15 & 0.09 & 0.05 & 0.12 & 0.29 & 0.07 & 0.14 & 0.06 & 0.16 & 0.09 \\
\hline \multirow{2}{*}{2} & \multirow{2}{*}{ Lhasa } & Mean & 0.08 & 0.12 & 0.15 & 0.18 & 0.14 & 0.13 & 0.12 & 0.11 & 0.10 & 0.08 & 0.08 & 0.08 \\
\hline & & Stdev & 0.02 & 0.09 & 0.05 & 0.08 & 0.06 & 0.05 & 0.06 & 0.03 & 0.03 & 0.03 & 0.02 & 0.02 \\
\hline \multirow{2}{*}{3} & \multirow{2}{*}{ Mt. Waliguan } & Mean & 0.09 & 0.13 & 0.24 & 0.23 & 0.18 & 0.18 & 0.19 & 0.16 & 0.12 & 0.10 & 0.06 & 0.05 \\
\hline & & Stdev & 0.07 & 0.08 & 0.19 & 0.16 & 0.10 & 0.09 & 0.06 & 0.06 & 0.06 & 0.04 & 0.03 & 0.04 \\
\hline \multirow{2}{*}{4} & \multirow{2}{*}{ Shangri-La } & Mean & 0.06 & 0.07 & 0.17 & 0.13 & 0.10 & 0.08 & 0.17 & 0.19 & 0.14 & 0.08 & 0.07 & 0.05 \\
\hline & & Stdev & 0.03 & 0.03 & 0.09 & 0.08 & 0.07 & 0.03 & 0.11 & 0.02 & 0.05 & 0.04 & 0.03 & 0.02 \\
\hline \multirow{2}{*}{5} & \multirow{2}{*}{ Ejina } & Mean & 0.18 & 0.21 & 0.34 & 0.39 & 0.35 & 0.29 & 0.26 & 0.27 & 0.23 & 0.16 & 0.14 & 0.16 \\
\hline & & Stdev & 0.10 & 0.15 & 0.26 & 0.30 & 0.31 & 0.29 & 0.19 & 0.24 & 0.22 & 0.16 & 0.08 & 0.10 \\
\hline \multirow{2}{*}{6} & \multirow{2}{*}{ Zhurihe } & Mean & 0.11 & 0.17 & 0.17 & 0.27 & 0.42 & 0.49 & 0.34 & 0.27 & 0.22 & 0.18 & 0.13 & 0.13 \\
\hline & & Stdev & 0.05 & 0.14 & 0.06 & 0.15 & 0.27 & 0.43 & 0.18 & 0.18 & 0.20 & 0.14 & 0.12 & 0.10 \\
\hline \multirow{2}{*}{7} & & Mean & 0.27 & 0.29 & 0.35 & 0.30 & 0.28 & 0.34 & 0.19 & 0.18 & 0.18 & 0.21 & 0.22 & 0.23 \\
\hline & Hami & Stdev & 0.17 & 0.14 & 0.20 & 0.21 & 0.15 & 0.30 & 0.11 & 0.09 & 0.09 & 0.12 & 0.09 & 0.11 \\
\hline & & Mean & 0.22 & 0.18 & 0.26 & 0.33 & 0.39 & 0.39 & 0.32 & 0.28 & 0.23 & 0.18 & 0.16 & 0.18 \\
\hline 8 & & Stdev & 0.17 & 0.08 & 0.18 & 0.22 & 0.26 & 0.30 & 0.23 & 0.20 & 0.19 & 0.12 & 0.09 & 0.14 \\
\hline 0 & & Mean & 0.23 & 0.24 & 0.30 & 0.33 & 0.39 & 0.44 & 0.35 & 0.28 & 0.24 & 0.21 & 0.19 & 0.21 \\
\hline 9 & & Stdev & 0.14 & 0.12 & 0.18 & 0.18 & 0.26 & 0.39 & 0.24 & 0.20 & 0.15 & 0.13 & 0.09 & 0.14 \\
\hline & & Mean & 0.18 & 0.20 & 0.25 & 0.32 & 0.41 & 0.45 & 0.27 & 0.35 & 0.32 & 0.27 & & 0.33 \\
\hline 10 & & Stdev & 0.12 & 0.14 & 0.13 & 0.12 & 0.21 & 0.26 & 0.13 & 0.29 & 0.21 & 0.15 & & 0.41 \\
\hline 11 & & Mean & 0.28 & 0.39 & 0.36 & 0.55 & 0.36 & 0.33 & 0.27 & 0.28 & 0.24 & 0.23 & 0.17 & 0.24 \\
\hline 11 & & Stdev & 0.11 & 0.26 & 0.22 & 0.40 & 0.23 & 0.19 & 0.09 & 0.15 & 0.10 & 0.11 & 0.04 & 0.13 \\
\hline & & Mean & 0.26 & 0.33 & 0.48 & 0.55 & 0.41 & 0.35 & 0.34 & 0.25 & 0.23 & 0.21 & 0.20 & 0.25 \\
\hline 12 & & Stdev & 0.17 & 0.20 & 0.33 & 0.41 & 0.24 & 0.22 & 0.23 & 0.19 & 0.12 & 0.11 & 0.09 & 0.14 \\
\hline & & Mean & 0.26 & 0.35 & 0.48 & 0.48 & 0.43 & 0.43 & 0.45 & 0.44 & 0.39 & 0.36 & 0.29 & 0.27 \\
\hline 13 & Minq1n & Stdev & 0.18 & 0.23 & 0.31 & 0.27 & 0.22 & 0.25 & 0.26 & 0.23 & 0.18 & 0.14 & 0.13 & 0.14 \\
\hline & & Mean & 0.30 & 0.44 & 0.75 & 0.91 & 0.77 & 0.73 & 0.64 & 0.61 & 0.51 & 0.30 & 0.22 & 0.26 \\
\hline 14 & $\mathrm{~T}$ & Stdev & 0.23 & 0.24 & 0.40 & 0.46 & 0.37 & 0.33 & 0.32 & 0.29 & 0.26 & 0.16 & 0.16 & 0.17 \\
\hline & & Mean & 0.45 & 0.71 & 0.71 & 0.74 & 0.81 & 0.72 & 0.72 & 0.81 & 0.60 & 0.43 & 0.31 & 0.37 \\
\hline 15 & $\mathrm{H}$ & Stdev & 0.27 & 0.42 & 0.43 & 0.45 & 0.48 & 0.43 & 0.48 & & 0.36 & 0.28 & 0.12 & 0.10 \\
\hline 16 & Dor & Mean & 0.29 & 0.41 & 0.47 & 0.55 & 0.47 & 0.72 & 0.55 & 0.56 & 0.52 & 0.36 & 0.26 & 0.31 \\
\hline 10 & D & Stdev & 0.15 & 0.22 & 0.35 & 0.24 & 0.22 & 0.44 & 0.28 & 0.29 & 0.32 & 0.19 & 0.08 & 0.15 \\
\hline 17 & & Mean & 0.33 & 0.42 & 0.39 & 0.45 & 0.39 & 0.49 & 0.49 & 0.54 & 0.37 & 0.21 & 0.23 & 0.26 \\
\hline 17 & & Stdev & 0.27 & 0.26 & 0.28 & 0.26 & 0.15 & 0.29 & 0.28 & 0.29 & 0.27 & 0.14 & 0.20 & 0.18 \\
\hline & & Mean & 0.38 & 0.38 & 0.35 & 0.43 & 0.38 & 0.44 & 0.39 & 0.39 & 0.46 & 0.39 & 0.25 & 0.26 \\
\hline 18 & & Stdev & 0.24 & 0.24 & 0.16 & 0.24 & 0.17 & 0.27 & 0.18 & 0.20 & 0.35 & 0.26 & 0.11 & 0.12 \\
\hline & & Mean & 0.45 & 0.55 & 0.58 & 0.59 & 0.49 & 0.42 & 0.40 & 0.41 & 0.46 & 0.45 & 0.38 & 0.38 \\
\hline 19 & & Stdev & 0.21 & 0.24 & 0.28 & 0.26 & 0.22 & 0.17 & 0.19 & 0.18 & 0.20 & 0.14 & 0.12 & 0.21 \\
\hline م0 & & Mean & 0.53 & 0.52 & 0.52 & 0.62 & 0.55 & 0.69 & 0.75 & 0.86 & 0.71 & 0.39 & 0.37 & 0.40 \\
\hline 20 & & Stdev & 0.39 & 0.34 & 0.32 & 0.34 & 0.32 & 0.42 & 0.37 & 0.42 & 0.46 & 0.26 & 0.30 & 0.33 \\
\hline 21 & & Mean & 0.82 & 0.73 & 0.82 & 0.58 & 0.49 & 0.45 & 0.40 & 0.47 & 0.70 & 0.56 & 0.57 & 0.51 \\
\hline 21 & & Stdev & 0.35 & 0.26 & 0.47 & 0.23 & 0.24 & 0.24 & 0.21 & 0.22 & 0.37 & 0.44 & 0.24 & 0.30 \\
\hline & & Mean & 0.32 & 0.31 & 0.32 & 0.46 & 0.41 & 0.42 & 0.30 & 0.30 & 0.27 & 0.32 & 0.29 & 0.30 \\
\hline 22 & $\Lambda$ & Stdev & 0.22 & 0.22 & 0.24 & 0.29 & 0.21 & 0.29 & 0.23 & 0.23 & 0.25 & 0.26 & 0.20 & 0.21 \\
\hline & & Mean & 0.15 & 0.28 & 0.28 & 0.37 & 0.42 & 0.58 & 0.51 & 0.43 & - & 0.15 & 0.16 & 0.09 \\
\hline 23 & & Stdev & 0.14 & 0.20 & 0.24 & 0.23 & 0.19 & 0.34 & 0.31 & 0.22 & - & 0.08 & 0.19 & 0.05 \\
\hline 24 & & Mean & 0.64 & 0.83 & 0.70 & 0.64 & 0.51 & 0.67 & 0.58 & 0.78 & 0.40 & 0.44 & 0.62 & 0.59 \\
\hline 24 & $\mathrm{~L}$ & Stdev & 0.37 & 0.43 & 0.32 & 0.22 & 0.19 & 0.50 & 0.45 & 0.39 & 0.21 & 0.23 & 0.30 & 0.27 \\
\hline 25 & & Mean & 0.32 & 0.37 & 0.49 & 0.57 & 0.58 & 0.72 & 0.56 & 0.60 & 0.51 & 0.43 & 0.34 & 0.31 \\
\hline 25 & $\mathrm{~S}$ & Stdev & 0.35 & 0.39 & 0.45 & 0.43 & 0.39 & 0.59 & 0.51 & 0.45 & 0.45 & 0.41 & 0.35 & 0.30 \\
\hline 26 & & Mean & 0.64 & 0.72 & 0.72 & 0.81 & 0.71 & 0.90 & 0.78 & 0.70 & 0.68 & 0.69 & 0.62 & 0.61 \\
\hline 26 & Huin & Stdev & 0.32 & 0.32 & 0.36 & 0.29 & 0.29 & 0.31 & 0.31 & 0.33 & 0.37 & 0.39 & 0.32 & 0.35 \\
\hline 27 & & Mean & 0.66 & 0.77 & 0.65 & 0.77 & 0.76 & 0.81 & 0.76 & 0.59 & 0.79 & 0.64 & 0.62 & 0.63 \\
\hline 21 & Guch & Stdev & 0.45 & 0.47 & 0.45 & 0.45 & 0.48 & 0.53 & 0.46 & 0.34 & 0.46 & 0.48 & 0.45 & 0.38 \\
\hline & & Mean & 0.83 & 0.84 & 0.81 & 0.81 & 0.78 & 0.96 & 0.58 & 0.72 & 0.90 & 0.82 & 0.65 & 0.65 \\
\hline 28 & & Stdev & 0.33 & 0.30 & 0.29 & 0.31 & 0.29 & 0.32 & 0.34 & 0.32 & 0.34 & 0.35 & 0.29 & 0.29 \\
\hline
\end{tabular}


Table A3. Continued.

\begin{tabular}{|c|c|c|c|c|c|c|c|c|c|c|c|c|c|c|}
\hline & Site & AOD & Jan & Feb & Mar & Apr & May & Jun & Jul & Aug & Sep & Oct & Nov & Dec \\
\hline \multirow{2}{*}{29} & \multirow{2}{*}{ Tongyu } & Mean & 0.18 & 0.13 & 0.21 & 0.35 & 0.44 & 0.44 & 0.32 & 0.20 & 0.17 & 0.36 & 0.15 & 0.18 \\
\hline & & Stdev & 0.16 & 0.06 & 0.19 & 0.33 & 0.44 & 0.42 & 0.26 & 0.14 & 0.14 & 0.34 & 0.13 & 0.18 \\
\hline \multirow{2}{*}{30} & \multirow{2}{*}{ Ürümqi } & Mean & 0.71 & 0.85 & 0.63 & 0.44 & 0.35 & 0.27 & 0.28 & 0.26 & 0.30 & 0.35 & 0.53 & 0.65 \\
\hline & & Stdev & 0.37 & 0.40 & 0.31 & 0.20 & 0.21 & 0.13 & 0.14 & 0.10 & 0.13 & 0.15 & 0.28 & 0.37 \\
\hline \multirow{2}{*}{31} & \multirow{2}{*}{ Datong } & Mean & 0.55 & 0.50 & 0.44 & 0.51 & 0.53 & 0.53 & 0.57 & 0.61 & 0.52 & 0.40 & 0.42 & 0.50 \\
\hline & & Stdev & 0.32 & 0.31 & 0.25 & 0.26 & 0.32 & 0.37 & 0.41 & 0.37 & 0.33 & 0.22 & 0.20 & 0.27 \\
\hline \multirow{2}{*}{32} & \multirow{2}{*}{ Yinchuan } & Mean & 0.56 & 0.42 & 0.68 & 0.47 & 0.52 & 0.48 & 0.47 & 0.64 & 0.47 & 0.43 & 0.56 & 0.51 \\
\hline & & Stdev & 0.28 & 0.24 & 0.30 & 0.17 & 0.17 & 0.22 & 0.22 & 0.16 & 0.19 & 0.14 & 0.27 & 0.24 \\
\hline \multirow{2}{*}{33} & \multirow{2}{*}{ Dalian } & Mean & 0.36 & 0.44 & 0.55 & 0.63 & 0.60 & 0.67 & 0.74 & 0.62 & 0.55 & 0.51 & 0.43 & 0.41 \\
\hline & & Stdev & 0.25 & 0.32 & 0.37 & 0.36 & 0.24 & 0.34 & 0.41 & 0.29 & 0.42 & 0.36 & 0.33 & 0.33 \\
\hline \multirow{2}{*}{34} & \multirow{2}{*}{ Tianjin } & Mean & 0.60 & 0.75 & 0.75 & 0.79 & 0.81 & 1.00 & 0.84 & 0.82 & 0.70 & 0.68 & 0.62 & 0.56 \\
\hline & & Stdev & 0.46 & 0.49 & 0.49 & 0.45 & 0.44 & 0.57 & 0.49 & 0.49 & 0.44 & 0.48 & 0.39 & 0.37 \\
\hline \multirow{2}{*}{35} & \multirow{2}{*}{ Beijing } & Mean & 0.69 & 0.69 & 0.81 & 0.86 & 0.81 & 1.10 & 0.83 & 0.83 & 0.64 & 0.63 & 0.63 & 0.58 \\
\hline & & Stdev & 0.51 & 0.47 & 0.58 & 0.49 & 0.50 & 0.48 & 0.54 & 0.49 & 0.51 & 0.53 & 0.46 & 0.45 \\
\hline \multirow{2}{*}{36} & \multirow{2}{*}{ Naning } & Mean & 0.77 & 0.72 & 1.20 & 1.02 & 0.75 & 0.60 & 0.67 & 0.91 & 0.79 & 1.04 & 0.63 & 0.74 \\
\hline & & Stdev & 0.24 & 0.22 & 0.33 & 0.40 & 0.29 & 0.30 & 0.39 & 0.52 & 0.34 & 0.51 & 0.28 & 0.27 \\
\hline \multirow{2}{*}{37} & \multirow{2}{*}{ Lanzhou } & Mean & 1.03 & 0.88 & 0.88 & 0.81 & 0.68 & 0.56 & 0.59 & 0.63 & 0.68 & 0.78 & 0.93 & 1.13 \\
\hline & & Stdev & 0.31 & 0.30 & 0.37 & 0.29 & 0.23 & 0.16 & 0.22 & 0.23 & 0.22 & 0.21 & 0.30 & 0.34 \\
\hline \multirow{2}{*}{38} & Xi'an & Mean & 0.86 & 1.07 & 1.02 & 0.81 & 0.83 & 0.81 & 0.97 & 1.17 & 0.86 & 0.83 & 0.80 & 0.77 \\
\hline & $X 1$ an & Stdev & 0.49 & 0.42 & 0.32 & 0.31 & 0.34 & 0.34 & 0.34 & 0.43 & 0.38 & 0.41 & 0.39 & 0.33 \\
\hline & & Mean & 0.87 & 1.04 & 1.00 & 0.91 & 0.90 & 1.08 & 1.00 & 1.14 & 0.97 & 0.91 & 0.74 & 0.70 \\
\hline 39 & Zhe & Stdev & 0.52 & 0.47 & 0.44 & 0.45 & 0.51 & 0.49 & 0.40 & 0.45 & 0.50 & 0.46 & 0.40 & 0.42 \\
\hline & & Mean & 1.09 & 1.24 & 1.30 & 1.07 & 0.87 & 0.88 & 0.89 & 1.20 & 0.74 & 0.50 & 0.79 & 1.16 \\
\hline 40 & Che & Stdev & 0.38 & 0.49 & 0.40 & 0.39 & 0.37 & 0.30 & 0.51 & 0.38 & 0.33 & 0.19 & 0.29 & 0.36 \\
\hline 41 & & Mean & 1.08 & 1.15 & 1.23 & 1.03 & 0.94 & 1.02 & 0.78 & 0.84 & 1.02 & 1.08 & 0.95 & 0.98 \\
\hline 41 & Han & Stdev & 0.50 & 0.39 & 0.47 & 0.55 & 0.34 & 0.68 & 0.69 & 0.48 & 0.48 & 0.55 & 0.44 & 0.38 \\
\hline 12 & & Mean & 0.50 & 0.90 & 0.67 & 0.97 & 1.04 & 1.26 & 0.90 & 0.81 & 0.63 & 0.69 & 0.60 & 0.65 \\
\hline 42 & Pudong & Stdev & 0.27 & 0.35 & 0.34 & 0.31 & 0.59 & 0.61 & 0.53 & 0.55 & 0.40 & 0.34 & 0.30 & 0.37 \\
\hline & & Mean & 0.81 & 0.89 & 1.03 & 0.71 & 0.92 & 1.15 & 0.72 & 0.59 & 0.75 & 0.76 & 0.80 & \\
\hline 43 & Hefe1 & Stdev & 0.22 & 0.26 & 0.28 & 0.25 & 0.21 & 0.18 & 0.34 & 0.24 & 0.25 & 0.18 & 0.40 & \\
\hline 44 & & Mean & 0.20 & 0.19 & 0.62 & 0.48 & 0.49 & 0.45 & 0.46 & 0.78 & 0.65 & 0.25 & 0.15 & 0.16 \\
\hline 44 & g & Stdev & 0.09 & 0.09 & 0.28 & 0.29 & 0.26 & 0.27 & 0.27 & 0.42 & 0.48 & 0.17 & 0.08 & 0.15 \\
\hline & & Mean & 0.77 & 1.08 & 1.22 & 0.98 & 0.67 & 0.60 & 0.46 & 0.53 & 0.91 & 0.86 & 0.66 & 0.58 \\
\hline 45 & Panyu & Stdev & 0.25 & 0.28 & 0.36 & 0.32 & 0.26 & 0.18 & 0.35 & 0.34 & 0.42 & 0.41 & 0.25 & 0.30 \\
\hline 46 & & Mean & 0.73 & 0.72 & 1.01 & 0.84 & 0.85 & 0.98 & 1.19 & 1.55 & 0.64 & 0.60 & 0.82 & 0.73 \\
\hline 46 & $\mathrm{~N}$ & Stdev & 0.26 & 0.46 & 0.68 & 0.18 & 0.42 & 0.21 & 0.48 & 0.49 & 0.17 & 0.31 & 0.24 & 0.29 \\
\hline 47 & Shenyang & Mean & & 1.07 & 0.71 & 0.78 & 0.89 & 0.90 & 1.01 & 0.66 & 0.61 & 0.54 & 0.62 & 0.51 \\
\hline 47 & shenyang & Stdev & & 0.40 & 0.43 & 0.34 & 0.33 & 0.50 & 0.51 & 0.43 & 0.42 & 0.40 & 0.39 & 0.32 \\
\hline 48 & Anshan & Mean & 0.56 & 0.75 & 0.44 & 0.78 & 1.08 & 0.80 & 0.92 & 0.72 & 0.77 & 0.51 & 0.57 & 0.43 \\
\hline 48 & Anshan & Stdev & 0.28 & 0.41 & 0.17 & 0.36 & 0.43 & 0.41 & 0.37 & 0.40 & 0.42 & 0.31 & 0.39 & 0.14 \\
\hline 49 & Beny & Mean & & 1.03 & 0.81 & 0.75 & 0.91 & 1.12 & 1.13 & 0.84 & 0.82 & 0.67 & 0.46 & \\
\hline 49 & Benx1 & Stdev & & 0.32 & 0.34 & 0.28 & 0.41 & 0.42 & 0.37 & 0.34 & 0.50 & 0.36 & 0.07 & \\
\hline & & Mean & 0.60 & 0.26 & & 0.49 & 0.50 & 0.41 & 0.66 & 0.59 & 0.45 & 0.40 & 0.55 & 0.48 \\
\hline 50 & Fushun & Stdev & 0.42 & 0.13 & & 0.21 & 0.31 & 0.22 & 0.41 & 0.44 & 0.39 & 0.18 & 0.33 & 0.25 \\
\hline
\end{tabular}


Table A4. Data of Figs. 6-15: AE between 440 and $870 \mathrm{~nm}$.

\begin{tabular}{|c|c|c|c|c|c|c|c|c|c|c|c|c|c|c|}
\hline & Site & $\mathrm{AE}_{440-870 \mathrm{~nm}}$ & Jan & $\mathrm{Feb}$ & Mar & Apr & May & Jun & Jul & Aug & Sep & Oct & Nov & Dec \\
\hline \multirow{2}{*}{1} & \multirow{2}{*}{ Akedala } & Mean & 1.45 & 1.23 & 0.90 & 1.00 & 0.88 & 0.96 & 1.18 & 1.24 & 1.02 & 1.20 & 1.19 & 1.32 \\
\hline & & Stdev & 0.39 & 0.37 & 0.67 & 0.31 & 0.26 & 0.28 & 0.24 & 0.22 & 0.35 & 0.44 & 0.46 & 0.39 \\
\hline \multirow{2}{*}{2} & \multirow{2}{*}{ Lhasa } & Mean & 0.80 & 0.62 & 0.53 & 0.73 & 0.76 & 0.85 & 0.94 & 1.22 & 1.16 & 1.07 & 1.08 & 0.92 \\
\hline & & Stdev & 0.32 & 0.25 & 0.20 & 0.24 & 0.23 & 0.27 & 0.32 & 0.35 & 0.25 & 0.26 & 0.22 & 0.27 \\
\hline \multirow{2}{*}{3} & \multirow{2}{*}{ Mt.Waliguan } & Mean & 0.61 & 0.36 & 0.25 & 0.35 & 0.40 & 0.56 & 0.96 & 0.74 & 0.65 & 0.77 & 0.75 & 0.65 \\
\hline & & Stdev & 0.33 & 0.23 & 0.14 & 0.22 & 0.33 & 0.26 & 0.38 & 0.32 & 0.24 & 0.27 & 0.28 & 0.33 \\
\hline \multirow{2}{*}{4} & \multirow{2}{*}{ Shangri-La } & Mean & 1.16 & 1.22 & 1.20 & 1.19 & 1.09 & 1.27 & 1.49 & 1.08 & 1.34 & 1.50 & 1.33 & 1.20 \\
\hline & & Stdev & 0.36 & 0.33 & 0.37 & 0.33 & 0.41 & 0.39 & 0.27 & 0.29 & 0.39 & 0.44 & 0.41 & 0.44 \\
\hline \multirow{2}{*}{5} & \multirow{2}{*}{ Ejina } & Mean & 0.73 & 0.56 & 0.35 & 0.35 & 0.39 & 0.49 & 0.58 & 0.61 & 0.68 & 0.64 & 0.73 & 0.72 \\
\hline & & Stdev & 0.37 & 0.34 & 0.27 & 0.25 & 0.26 & 0.29 & 0.32 & 0.32 & 0.34 & 0.29 & 0.33 & 0.37 \\
\hline \multirow{2}{*}{6} & \multirow{2}{*}{ Zhurihe } & Mean & 1.08 & 0.80 & 0.48 & 0.42 & 0.80 & 0.87 & 0.87 & 0.73 & 0.75 & 0.70 & 0.94 & 1.15 \\
\hline & & Stdev & 0.28 & 0.40 & 0.19 & 0.30 & 0.45 & 0.35 & 0.35 & 0.51 & 0.36 & 0.38 & 0.44 & 0.30 \\
\hline \multirow{2}{*}{7} & & Mean & 0.86 & 0.51 & 0.39 & 0.50 & 0.72 & 0.68 & 0.75 & 0.71 & 0.71 & 0.55 & 0.45 & 0.62 \\
\hline & Hami & Stdev & 0.25 & 0.24 & 0.27 & 0.37 & 0.45 & 0.35 & 0.30 & 0.29 & 0.34 & 0.28 & 0.28 & 0.25 \\
\hline & & Mean & 0.69 & 0.74 & 0.73 & 0.75 & 0.78 & 0.86 & 0.88 & 0.89 & 0.89 & 0.76 & 0.73 & 0.82 \\
\hline 8 & Xilinhot & Stdev & 0.35 & 0.48 & 0.48 & 0.44 & 0.40 & 0.42 & 0.39 & 0.41 & 0.44 & 0.46 & 0.42 & 0.35 \\
\hline & & Mean & 0.86 & 0.62 & 0.53 & 0.48 & 0.92 & 0.89 & 0.88 & 0.81 & 0.74 & 0.71 & 0.74 & 0.84 \\
\hline 9 & Wulate & Stdev & 0.36 & 0.27 & 0.28 & 0.24 & 0.44 & 0.45 & 0.47 & 0.42 & 0.42 & 0.31 & 0.37 & 0.36 \\
\hline & & Mean & 0.56 & 0.48 & 0.48 & 0.39 & 0.62 & 0.76 & 0.62 & 0.54 & 0.66 & 0.50 & & 0.53 \\
\hline 10 & Zhangbeı & Stdev & 0.20 & 0.19 & 0.17 & 0.15 & 0.25 & 0.19 & 0.22 & 0.33 & 0.31 & 0.28 & & 0.22 \\
\hline & & Mean & 0.67 & 0.59 & 0.40 & 0.31 & 0.46 & 0.51 & 0.47 & 0.46 & 0.37 & 0.47 & 0.65 & 0.68 \\
\hline 11 & Jiuquan & Stdev & 0.25 & 0.39 & 0.24 & 0.29 & 0.30 & 0.33 & 0.26 & 0.25 & 0.12 & 0.18 & 0.17 & 0.24 \\
\hline & & Mean & 0.65 & 0.47 & 0.27 & 0.26 & 0.33 & 0.36 & 0.38 & 0.46 & 0.50 & 0.51 & 0.65 & 0.65 \\
\hline 12 & Dunhuang & Stdev & 0.27 & 0.30 & 0.21 & 0.22 & 0.23 & 0.23 & 0.30 & 0.28 & 0.29 & 0.24 & 0.28 & 0.33 \\
\hline & & Mean & 0.84 & 0.54 & 0.36 & 0.35 & 0.39 & 0.44 & 0.57 & 0.53 & 0.57 & 0.57 & 0.61 & 0.66 \\
\hline 13 & Minqin & Stdev & 0.36 & 0.31 & 0.25 & 0.21 & 0.26 & 0.23 & 0.30 & 0.25 & 0.35 & 0.32 & 0.41 & 0.40 \\
\hline 14 & & Mean & 0.61 & 0.36 & 0.12 & 0.10 & 0.10 & 0.11 & 0.15 & 0.17 & 0.21 & 0.36 & 0.56 & 0.57 \\
\hline 14 & lazhong & Stdev & 0.32 & 0.29 & 0.08 & 0.06 & 0.07 & 0.07 & 0.09 & 0.11 & 0.09 & 0.19 & 0.27 & 0.34 \\
\hline 15 & & Mean & 0.66 & 0.18 & 0.13 & 0.07 & 0.06 & 0.07 & 0.15 & 0.08 & 0.11 & 0.20 & 0.39 & 0.59 \\
\hline 15 & Hotan & Stdev & 0.26 & 0.13 & 0.14 & 0.07 & 0.06 & 0.07 & 0.13 & 0.06 & 0.07 & 0.10 & 0.16 & 0.20 \\
\hline & & Mean & 0.87 & 0.69 & 0.50 & 0.44 & 0.74 & 0.91 & 0.98 & 1.21 & 0.88 & 0.73 & 0.72 & 0.81 \\
\hline 16 & Dongsheng & Stdev & 0.20 & 0.27 & 0.27 & 0.33 & 0.30 & 0.29 & 0.28 & 0.39 & 0.35 & 0.30 & 0.29 & 0.25 \\
\hline & & Mean & 0.98 & 0.59 & 0.59 & 0.67 & 0.54 & 0.64 & 0.92 & 1.25 & 1.02 & 0.93 & 0.93 & 0.80 \\
\hline 17 & 1011 & Stdev & 0.37 & 0.22 & 0.31 & 0.32 & 0.26 & 0.36 & 0.35 & 0.23 & 0.33 & 0.29 & 0.27 & 0.30 \\
\hline & & Mean & 1.04 & 0.65 & 0.63 & 0.60 & 0.65 & 1.05 & 0.97 & 1.01 & 1.14 & 0.97 & 1.01 & 0.91 \\
\hline 18 & Y & Stdev & 0.21 & 0.28 & 0.23 & 0.28 & 0.27 & 0.24 & 0.35 & 0.15 & 0.25 & 0.25 & 0.23 & 0.29 \\
\hline 10 & & Mean & 0.94 & 0.77 & 0.64 & 0.57 & 0.56 & 0.84 & 0.88 & 0.87 & 0.79 & 0.91 & 0.86 & 0.77 \\
\hline 19 & Mt. Gaolan & Stdev & 0.31 & 0.31 & 0.30 & 0.28 & 0.30 & 0.40 & 0.38 & 0.31 & 0.29 & 0.26 & 0.36 & 0.32 \\
\hline & & Mean & 1.05 & 1.04 & 0.78 & 0.76 & 0.82 & 1.11 & 1.20 & 1.25 & 1.20 & 1.04 & 1.02 & 1.01 \\
\hline 20 & Yushe & Stdev & 0.27 & 0.27 & 0.31 & 0.34 & 0.34 & 0.29 & 0.23 & 0.26 & 0.30 & 0.26 & 0.26 & 0.34 \\
\hline & & Mean & 1.36 & 1.26 & 0.96 & 0.79 & 0.93 & 1.28 & 1.27 & 1.38 & 1.40 & 1.30 & 1.36 & 0.93 \\
\hline 21 & Char & Stdev & 0.12 & 0.20 & 0.39 & 0.25 & 0.29 & 0.11 & 0.27 & 0.30 & 0.16 & 0.24 & 0.20 & 0.23 \\
\hline & & Mean & 1.35 & 1.37 & 1.38 & 1.33 & 1.26 & 1.39 & 1.49 & 1.43 & 1.42 & 1.42 & 1.42 & 1.32 \\
\hline 22 & gfeng & Stdev & 0.28 & 0.34 & 0.36 & 0.36 & 0.38 & 0.30 & 0.29 & 0.26 & 0.33 & 0.35 & 0.29 & 0.29 \\
\hline & & Mean & 1.14 & 1.06 & 1.00 & 0.79 & 0.42 & 1.30 & 1.14 & 1.03 & & 0.98 & 1.02 & 1.34 \\
\hline 23 & 1 & Stdev & 0.41 & 0.35 & 0.34 & 0.35 & 0.07 & 0.13 & 0.17 & 0.12 & & 0.22 & 0.23 & 0.37 \\
\hline 24 & & Mean & 1.21 & 0.99 & 1.03 & 1.00 & 1.19 & 1.21 & 1.20 & 1.29 & 1.05 & 1.09 & 1.20 & 1.12 \\
\hline 24 & n & Stdev & 0.24 & 0.34 & 0.26 & 0.26 & 0.24 & 0.28 & 0.41 & 0.23 & 0.31 & 0.28 & 0.28 & 0.32 \\
\hline 25 & 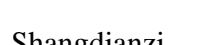 & Mean & 1.11 & 1.11 & 1.00 & 0.92 & 0.96 & 1.17 & 1.19 & 1.25 & 1.20 & 1.18 & 1.14 & 1.08 \\
\hline 25 & anz1 & Stdev & 0.29 & 0.31 & 0.35 & 0.36 & 0.40 & 0.29 & 0.26 & 0.26 & 0.26 & 0.26 & 0.31 & 0.34 \\
\hline & & Mean & 1.16 & 1.09 & 0.97 & 0.96 & 0.95 & 1.19 & 1.25 & 1.32 & 1.33 & 1.22 & 1.26 & 1.03 \\
\hline 26 & imin & Stdev & 0.20 & 0.28 & 0.31 & 0.32 & 0.35 & 0.21 & 0.16 & 0.17 & 0.26 & 0.22 & 0.15 & 0.32 \\
\hline & & Mean & 1.36 & 1.23 & 1.10 & 1.16 & 1.06 & 1.22 & 1.27 & 1.34 & 1.26 & 1.32 & 1.35 & 1.22 \\
\hline 27 & Gucheng & Stdev & 0.26 & 0.30 & 0.37 & 0.34 & 0.32 & 0.31 & 0.24 & 0.30 & 0.34 & 0.27 & 0.26 & 0.40 \\
\hline & & Mean & 1.27 & 1.30 & 1.13 & 0.97 & 1.18 & 1.24 & 1.26 & 1.44 & 1.39 & 1.38 & 1.40 & 1.29 \\
\hline 28 & Lin'an & Stdev & 0.26 & 0.28 & 0.27 & 0.32 & 0.30 & 0.33 & 0.43 & 0.30 & 0.25 & 0.28 & 0.21 & 0.33 \\
\hline
\end{tabular}


Table A4. Continued.

\begin{tabular}{|c|c|c|c|c|c|c|c|c|c|c|c|c|c|c|}
\hline & Site & $\mathrm{AE}_{440-870 \mathrm{~nm}}$ & Jan & Feb & Mar & Apr & May & Jun & Jul & Aug & Sep & Oct & Nov & Dec \\
\hline \multirow{2}{*}{29} & \multirow{2}{*}{ Tongyu } & Mean & 1.92 & 1.90 & 1.34 & 1.04 & 1.05 & 1.21 & 1.27 & 1.13 & 1.08 & 1.26 & 1.44 & 1.55 \\
\hline & & Stdev & 0.66 & 0.55 & 0.39 & 0.38 & 0.39 & 0.32 & 0.33 & 0.29 & 0.37 & 0.42 & 0.47 & 0.64 \\
\hline \multirow{2}{*}{30} & \multirow{2}{*}{ Ürümqi } & Mean & 1.08 & 1.02 & 0.91 & 0.74 & 0.78 & 0.85 & 1.05 & 0.92 & 0.91 & 0.99 & 1.13 & 1.15 \\
\hline & & Stdev & 0.23 & 0.23 & 0.33 & 0.37 & 0.39 & 0.31 & 0.32 & 0.29 & 0.29 & 0.25 & 0.24 & 0.28 \\
\hline \multirow{2}{*}{31} & \multirow{2}{*}{ Datong } & Mean & 0.91 & 0.80 & 0.68 & 0.63 & 0.72 & 0.86 & 0.94 & 0.99 & 0.98 & 0.84 & 0.86 & 0.90 \\
\hline & & Stdev & 0.19 & 0.25 & 0.28 & 0.32 & 0.34 & 0.33 & 0.25 & 0.25 & 0.27 & 0.25 & 0.24 & 0.22 \\
\hline \multirow{2}{*}{32} & \multirow{2}{*}{ Yinchuan } & Mean & 1.04 & 0.74 & 0.56 & 0.58 & 0.85 & 0.94 & 1.02 & 0.99 & 0.78 & 0.99 & 0.93 & 1.00 \\
\hline & & Stdev & 0.18 & 0.29 & 0.24 & 0.20 & 0.34 & 0.24 & 0.26 & 0.17 & 0.20 & 0.16 & 0.20 & 0.22 \\
\hline \multirow{2}{*}{33} & \multirow{2}{*}{ Dalian } & Mean & 0.95 & 0.96 & 0.94 & 1.04 & 1.11 & 1.21 & 1.25 & 1.26 & 1.24 & 1.31 & 1.26 & 1.04 \\
\hline & & Stdev & 0.27 & 0.33 & 0.30 & 0.37 & 0.35 & 0.27 & 0.22 & 0.31 & 0.35 & 0.23 & 0.22 & 0.31 \\
\hline \multirow{2}{*}{34} & \multirow{2}{*}{ Tianjin } & Mean & 1.07 & 1.06 & 0.93 & 0.88 & 0.96 & 1.15 & 1.14 & 1.24 & 1.18 & 1.13 & 1.17 & 1.08 \\
\hline & & Stdev & 0.30 & 0.28 & 0.30 & 0.33 & 0.34 & 0.25 & 0.25 & 0.26 & 0.30 & 0.28 & 0.32 & 0.33 \\
\hline \multirow{2}{*}{35} & \multirow{2}{*}{ Beijing } & Mean & 0.98 & 0.94 & 0.87 & 0.79 & 0.89 & 1.14 & 1.10 & 1.21 & 1.11 & 1.10 & 1.04 & 0.99 \\
\hline & & Stdev & 0.34 & 0.39 & 0.34 & 0.37 & 0.33 & 0.25 & 0.29 & 0.28 & 0.26 & 0.27 & 0.32 & 0.32 \\
\hline \multirow{2}{*}{36} & \multirow{2}{*}{ Naning } & Mean & 1.62 & 1.64 & 1.50 & 1.43 & 1.42 & 1.22 & 1.37 & 1.66 & 1.63 & 1.52 & 1.59 & 1.45 \\
\hline & & Stdev & 0.14 & 0.14 & 0.27 & 0.30 & 0.30 & 0.25 & 0.56 & 0.26 & 0.40 & 0.27 & 0.14 & 0.18 \\
\hline \multirow{2}{*}{37} & \multirow{2}{*}{ Lanzhou } & Mean & 1.03 & 0.86 & 0.65 & 0.58 & 0.70 & 0.92 & 1.02 & 1.01 & 1.03 & 1.04 & 1.11 & 1.05 \\
\hline & & Stdev & 0.22 & 0.31 & 0.32 & 0.29 & 0.27 & 0.26 & 0.23 & 0.22 & 0.19 & 0.19 & 0.23 & 0.22 \\
\hline \multirow{2}{*}{38} & Xi'an & Mean & 0.97 & 0.88 & 0.73 & 0.59 & 0.79 & 0.88 & 1.03 & 1.15 & 0.99 & 1.00 & 0.83 & 0.91 \\
\hline & $X 1$ an & Stdev & 0.30 & 0.32 & 0.36 & 0.33 & 0.36 & 0.39 & 0.35 & 0.29 & 0.32 & 0.32 & 0.28 & 0.27 \\
\hline & & Mean & 1.15 & 1.15 & 0.82 & 0.82 & 0.91 & 1.18 & 1.25 & 1.26 & 1.24 & 1.25 & 1.12 & 0.99 \\
\hline 39 & Zher & Stdev & 0.26 & 0.26 & 0.34 & 0.32 & 0.34 & 0.25 & 0.21 & 0.23 & 0.25 & 0.27 & 0.32 & 0.36 \\
\hline & & Mean & 1.11 & 1.04 & 0.93 & 0.98 & 0.97 & 1.11 & 1.19 & 1.21 & 1.05 & 1.11 & 1.24 & 1.10 \\
\hline 40 & Chengdu & Stdev & 0.20 & 0.16 & 0.32 & 0.35 & 0.28 & 0.22 & 0.20 & 0.14 & 0.25 & 0.28 & 0.16 & 0.17 \\
\hline & & Mean & 1.34 & 1.30 & 1.21 & 1.09 & 1.22 & 1.27 & 1.18 & 1.29 & 1.33 & 1.38 & 1.22 & 1.08 \\
\hline 41 & Hang & Stdev & 0.14 & 0.21 & 0.22 & 0.20 & 0.28 & 0.20 & 0.23 & 0.19 & 0.23 & 0.15 & 0.27 & 0.38 \\
\hline 42 & & Mean & 1.37 & 1.27 & 1.04 & 1.14 & 1.19 & 1.23 & 1.31 & 1.28 & 1.24 & 1.41 & 1.38 & 1.26 \\
\hline 42 & Pudong & Stdev & 0.24 & 0.22 & 0.30 & 0.25 & 0.32 & 0.23 & 0.29 & 0.23 & 0.52 & 0.17 & 0.14 & 0.31 \\
\hline & & Mean & 1.30 & 1.22 & 0.94 & 0.89 & 1.14 & 1.19 & 1.14 & 1.35 & 1.38 & 1.37 & 1.13 & \\
\hline 43 & Hefeı & Stdev & 0.22 & 0.26 & 0.28 & 0.25 & 0.21 & 0.18 & 0.34 & 0.24 & 0.25 & 0.18 & 0.40 & \\
\hline 44 & & Mean & 1.55 & 1.69 & 1.52 & 1.32 & 1.14 & 0.98 & 0.90 & 1.06 & 1.00 & 1.32 & 1.24 & 1.21 \\
\hline 44 & Kuming & Stdev & 0.29 & 0.19 & 0.17 & 0.18 & 0.27 & 0.36 & 0.47 & 0.23 & 0.43 & 0.16 & 0.24 & 0.25 \\
\hline & & Mean & 1.35 & 1.37 & 1.42 & 1.30 & 1.39 & 1.49 & 1.14 & 1.26 & 1.45 & 1.48 & 1.32 & 1.34 \\
\hline 45 & Panyu & Stdev & 0.05 & 0.04 & 0.12 & 0.21 & 0.18 & 0.13 & 0.34 & 0.26 & 0.19 & 0.11 & 0.11 & 0.17 \\
\hline & & Mean & 1.29 & 1.18 & 1.09 & 1.01 & 0.99 & 1.27 & 1.35 & 1.34 & 1.34 & 1.37 & 1.34 & 1.36 \\
\hline 46 & Nanjıng & Stdev & 0.17 & 0.33 & 0.23 & 0.17 & 0.38 & 0.09 & 0.14 & 0.20 & 0.13 & 0.14 & 0.10 & 0.16 \\
\hline 47 & Shenyang & Mean & & 0.48 & 0.84 & 0.79 & 0.69 & 0.87 & 0.73 & 0.94 & 1.05 & 1.11 & 1.16 & 1.07 \\
\hline $4 /$ & shenyang & Stdev & & 0.17 & 0.45 & 0.31 & 0.28 & 0.25 & 0.27 & 0.26 & 0.23 & 0.29 & 0.18 & 0.17 \\
\hline 48 & Anshan & Mean & 0.72 & 0.95 & 0.83 & 0.59 & 0.29 & 0.75 & 0.79 & 0.66 & 1.09 & 1.06 & 0.88 & 0.87 \\
\hline 48 & Anshan & Stdev & 0.51 & 0.26 & 0.24 & 0.23 & 0.15 & 0.30 & 0.18 & 0.32 & 0.20 & 0.23 & 0.31 & 0.23 \\
\hline 40 & Renyi & Mean & & 0.64 & 0.42 & 0.59 & 0.41 & 0.53 & 0.39 & 0.49 & 0.72 & 0.55 & 0.51 & \\
\hline 49 & Benx1 & Stdev & & 0.14 & 0.26 & 0.22 & 0.14 & 0.26 & 0.21 & 0.21 & 0.35 & 0.23 & 0.15 & \\
\hline & & Mean & 0.95 & 1.03 & & 0.20 & 0.84 & 0.77 & 0.52 & 1.01 & 0.81 & 0.95 & 1.03 & 1.07 \\
\hline 50 & Fushun & Stdev & 0.22 & 0.14 & & 0.27 & 0.36 & 0.32 & 0.69 & 0.26 & 0.26 & 0.26 & 0.25 & 0.17 \\
\hline
\end{tabular}




\section{The Supplement related to this article is available online at doi:10.5194/acp-15-7619-2015-supplement.}

Acknowledgements. This research was funded by the National Key Project of Basic Research (2011CB403401), the Project (41275167 and 41130104) supported by the National Natural Science Foundation of China, Strategic Priority Research Program of the Chinese Academy of Sciences (XDA05100301), CAMS Basis Research Project (2014R17) and the Climate Change Special Fund of CMA (CCSF201504). The research leading to these results has received funding from the European Union Seventh Framework Programme (FP7/2007-2013) under grant agreement no. 262254.

Edited by: S. Gong

\section{References}

Alfaro, S. C., Gomes, L., Rajot, J. L., Lafon, S., Gaudichet, A., Chatenet, B., Maille, M., Cautenet, G., Lasserre, F., Cachier, H., and Zhang, X. Y.: Chemical and optical characterization of aerosols measured in spring 2002 at the ACE-Asia supersite, Zhenbeitai, China, J. Geophys. Res., 108, 8641, doi:10.1029/2002JD003214, 2003.

Andreae, M. O., Schmid, Yang, H., Chand, D., Yu, J., Zeng, L., and Zhang, Y.: Optical properties and chemical composition of the atmospheric aerosol in urban Guangzhou, China, Atmos. Environ., 42, 6335-6350, 2008.

Bi, J., Huang, J., Fu, Q., Wang, X., Shi, J., Zhang, W., Huang, Z., and Zhang, B.: Toward characterization of the aerosol optical properties over Loess Plateau of Northwestern China, J. Quan. Spec. Rad. Trans., 112, 346-360, 2011.

Bokoye, A. I., Royer, A., O’neill, N. T., Cliche, P., Fedosejevs, G., Teillet, P. M., and McArthur, L. J. B.: Characterization of atmospheric aerosols across Canada from a ground-based sunphotometer network: Aerocan, Atmos. Ocean., 39, 429-456, 2001.

Charlson, R. J., Schwartz, S. E., Hales, J. M., Cess, D., Coakley, J. A., and Hansen, J. E.: Climate forcing by anthropogenic aerosols, Science, 255, 423-430, 1992.

Chaudhry, Z., Martins, J. V., Li, Z., Tsay, S.-C., Chen, H., Wang, P., Wen, T. , Li, C., and Dickerson, R. R.: In situ measurements of aerosol mass concentration and radiative properties in Xianghe, southeast of Beijing, J. Geophys. Res., 112, D23S90, doi:10.1029/2007JD009055, 2007.

Che, H. Z., Shi, G. Y., Zhang, X. Y., Arimoto, R., Zhao, J. Q., Xu, L., Wang, B., and Chen, Z. H.: Analysis of 40 years of solar radiation data from China, 1961-2000, Geophys. Res. Lett., 32, L06803, doi:10.1029/2004GL022322, 2005.

Che, H., Zhang, X., Li, Y., Zhou, Z., and Qu, J. J.: Horizontal visibility trends in China 1981-2005, Geophys. Res. Lett., 34, L24706, doi:10.1029/2007GL031450, 2007.

Che, H., Shi, G., Uchiyama, A., Yamazaki, A., Chen, H., Goloub, P., and Zhang, X.: Intercomparison between aerosol optical properties by a PREDE skyradiometer and CIMEL sunphotometer over Beijing, China, Atmos. Chem. Phys., 8, 3199-3214, doi:10.5194/acp-8-3199-2008, 2008.
Che, H., Yang, Z., Zhang, X., Zhu, C., Ma, Q., Zhou, H., and Wang, P.: Study on the aerosol optical properties and their relationship with aerosol chemical compositions over three regional background stations in China, Atmos. Environ., 43, 1093-1099, doi:10.1016/j.atmosenv.2008.11.010, 2009a.

Che, H. Z., Zhang, X. Y., Alfraro, S., Chatenet, B., Gomes, L., and Zhao, J. Q.: Aerosol optical properties and its radiative forcing over Yulin, China in 2001 and 2002, Adv. Atmos. Sci., 26, 564576, doi:10.1007/s00376-009-0564-4, 2009b.

Che, H., Zhang, X. Y., Chen, H. B., Damiri, B., Goloub, P., Li, Z. Q., Zhang, X. C., Wei, Y., Zhou, H. G., Dong, F., Li, D. P., and Zhou, T. M.: Instrument calibration and aerosol optical depth validation of the China Aerosol Remote Sensing Network, J. Geophys. Res., 114, D03206, doi:10.1029/2008JD011030, 2009c.

Che, H., Wang, Y., and Sun, J.: Aerosol optical properties at Mt. Waliguan observatory, China, Atmos. Environ., 45, 6004-6009, 2011.

Che, H., Wang, Y., Sun, J., Zhang, X., Zhang, X., and Guo, J.: Variation of Aerosol Optical Properties over the Taklimakan Desert in China, Aerosol Air Qual. Res., 13, 777-785, 2013.

Che, H., Xia, X., Zhu, J., Li, Z., Dubovik, O., Holben, B., Goloub, P., Chen, H., Estelles, V., Cuevas-Agulló, E., Blarel, L., Wang, H., Zhao, H., Zhang, X., Wang, Y., Sun, J., Tao, R., Zhang, X., and Shi, G.: Column aerosol optical properties and aerosol radiative forcing during a serious haze-fog month over North China Plain in 2013 based on ground-based sunphotometer measurements, Atmos. Chem. Phys., 14, 2125-2138, doi:10.5194/acp14-2125-2014, 2014.

Che, H., Xia, X., Zhu, J., Wang, H., Wang, Y., Sun, J., Zhang, X., and Shi, G.: Aerosol optical properties under the condition of heavy haze over an urban site of Beijing, China, Environ. Sci. Pollut. R., 22, 1043-1053, doi:10.1007/s11356-014-3415-5, 2015 a.

Che, H., Zhao, H., Wu, Y., Xia, X., Zhu, J., Wang, H., Wang, Y., Sun, J., Yu, J., Zhang, X., and Shi, G.: Analyses of aerosol optical properties and direct radiative forcing over urban and industrial regions in Northeast China, Meteorol. Atmos. Phys., 127, 345354, doi:10.1007/s00703-015-0367-3, 2015b.

Chen, D., Cheng, S., Zhou, Y., Guo, X., Fan, S., and Wang, H.: Impact of road fugitive dust on air quality in Beijing, China, Environ. Eng. Sci., 27, 825-834, doi:10.1089/ees.2009.0122, 2010.

Chen, J., Jiang, H., Wang, B., Xiao, Z., Jiang, Z., Zhou, G., and Yu, S: Aerosol optical properties from Sun-photometric measurements in Hangzhou, China, Int. J. Remote. Sens., 33, 2451-2461, doi:10.1080/01431161.2011.611184, 2012.

Chen, R., Li, Y., Ma, Y., Pan, G., Zeng, G., Xu, X., Chen, B., and Kan, H.: Coarse particles and mortality in three Chinese cities: the China Air Pollution and Health Effects Study (CAPES), Sci. Total Environ., 409, 4934-4938, 2011.

Chen, W., Chen, Y., Chou, C.K., Chang, S., Lin, P., and Chen, J.: Columnar optical properties of tropospheric aerosol by combined lidar and sunphotometer measurements at Taipei, Taiwan, Atmos. Environ., 43, 2700-2708, 2009.

Cheng, T., Liu, Y., Lu, D., Xu, Y., and Li, H.: Aerosol properties and radiative forcing in Hunshan Dake desert, northern China, Atmos. Environ., 40, 2169-2179, doi:10.1016/j.atmosenv.2005.11.054, 2006.

Cheng, T., Xu, C., Duan, J., Wang, Y., Leng, C., Tao, J., Che, H., He, Q., Wu, Y., Zhang, R., Li, X., Chen, J., Kong, L., and Yu, 
X.: Seasonal variation and difference of aerosol optical properties in columnar and surface atmospheres over Shanghai, Atmos. Environ., in press, doi:10.1016/j.atmosenv.2015.05.029, 2015.

Cheng, Z., Wang, S., Fu, X., Watson, J. G., Jiang, J., Fu, Q., Chen, C., Xu, B., Yu, J., Chow, J. C., and Hao, J.: Impact of biomass burning on haze pollution in the Yangtze River delta, China: a case study in summer 2011, Atmos. Chem. Phys., 14, 45734585, doi:10.5194/acp-14-4573-2014, 2014.

Chin, M.: Atmospheric science: Dirtier air from a weaker monsoon, Nat. Geosci., 5, 449-450, 2012.

Cong, Z. Y., Kang, S. C., Smirnov, A., and Holben, B.: Aerosol optical properties at Nam Co, a remote site in central Tibetan Plateau, Atmos. Res. 92, 42-48, doi:10.1016/j.atmosenv.2010.04.013, 2009.

Dubovik, O. and King, M. D.: A flexible inversion algorithm for the retrieval of aerosol optical properties from Sun and sky radiance measurements, J. Geophys. Res., 105, 20673-20696, doi:10.1029/2000JD900282, 2000.

Dubovik, O., Smirnov, A., Holben, B. N., King, M. D., Kaufman, Y. J., Eck, T. F., and Slutsker, I.: Accuracy assessments of aerosol optical properties retrieved from Aerosol Robotic Network (AERONET) Sun and sky radiance measurements, J. Geophys. Res.-Atmos., 105, 9791-9806, 2000.

Dubovik, O., Sinyuk, A., Lapyonok, T., Holben, B. N., Mishchenko, M., Yang, P., Eck, T. F., Volten, H., Munoz, O., Veihelmann, B., van der Zande, W. J., Leon, J. F., Sorokin, M., and Slutsker, I.: Application of spheroid models to account for aerosol particle nonsphericity in remote sensing of desert dust, J. Geophys. Res.Atmos., 111, D11208, doi:10.1029/2005jd006619, 2006.

Eck, T. F., Holben, B. N., Reid, J. S., Dubovik, O., Smirnov, A., O'Neill, N. T., Slutsker, I., and Kinne, S.: Wavelength dependence of the optical depth of biomass burning, urban, and desert dust aerosols, J. Geophys. Res., 104, 31333-31349, 1999.

Eck, T. F., Holben, B. N., Dubovik, O., Smirnov, A., Goloub, P., Chen, H. B., Chatenet, B., Gomes, L., Zhang, X. Y., Tsay, S. C., Ji, Q., Giles, D., and Slutsker, I.: Columnar aerosol optical properties at AERONET sites in central eastern Asia and aerosol transport to the tropical mid-Pacific, J. Geophys. Res., 110, D06202, doi:10.1029/2004JD005274, 2005.

Eck, T. F., Holben, B. N., Sinyuk, A., Pinker, R. T., Goloub, P., Chen, H., Chatenet, B., Li, Z., Singh, R. P., Tripathi, S. N., Reid, J. S., Giles, D. M., Dubovik, O., O’Neill, N. T., Smirnov, A., Wang, P., and Xia, X.: Climatological aspects of the optical properties of fine/coarse mode aerosol mixtures, J. Geophys. Res., 115, D19205, doi:10.1029/2010JD014002, 2010.

Fan, S., Tian, G., Li, G., Huang, Y., Qin, J., and Cheng, S.: Road fugitive dust emission characteristics in Beijing during Olympics Game 2008 in Beijing, China, Atmos. Environ., 43, 6003-6010, 2009.

Fan, X., Chen, H., Goloub, P., Xia, X., Zhang, W., and Chatenet, B.: Analysis of column-integrated aerosol optical thickness in Beijing from AERONET observations, China Particuology, 4, 330335,2006

Fan, X. H., Xia, X. A., and Chen, H. B.: Comparison of columnintegrated aerosol optical and physical properties in an urban and suburban site on the North China Plain, Adv. Atmos. Sci., 32, 477-486, doi:10.1007/s00376-014-4097-0, 2015.
Fu, G., Yu, J., Zhang, Y., and Hu, S.: Temporal variation of wind speed in China for 1961-2007, Theor. Appl. Climatol., 104, 313 324, 2011.

Goloub, P., Li, Z., Dubovik, O., Blarel, L., Podvin, T., Jankowiak, I., Lecoq, R., Deroo, C., Chatenet, B., Morel, J. P., Cuevas, E., and Ramos, R.: PHOTONS/AERONET sunphotometer network overview: description, activities, results, Proc. SPIE 6936, 69360V, doi:10.1117/12.783171, 2007.

Gong, S. L., Zhang, X. Y., Zhao, T. L., McKendry, I. G., Jaffe, D. A., and Lu, N. M.: Characterization of soil dust aerosol in China and its transport and distribution during 2001 ACE-Asia: 2. Model simulation and validation, J. Geophys. Res., 108, 4262, doi:10.1029/2002JD002633, 2003.

Gong, W., Zhang, S., and Ma, Y.: Aerosol optical properties and determination of aerosol size distribution in Wuhan, China, Atmosphere, 5, 81-91, doi:10.3390/atmos5010081, 2014.

Hänel, A., Baars, H., Althausen, D., Ansmann, A., Engelmann, R., and Sun, J. Y.,: One-year aerosol profiling with EUCAARI Raman lidar at Shangdianzi GAW station: Beijing plume and seasonal variations, J. Geophys. Res., 117, D13201, doi:10.1029/2012JD017577, 2012.

Hansen, J., Sato, M., and Ruedy, R.: Radiative forcing and climate response, J. Geophys. Res., 102, 6831-6864, doi:10.1029/96JD03436, 1997.

Hansen, J., Sato, M., Ruedy, R., Lacis, A., and Oinas, V.: Global warming in the twenty-first century: An alternative scenario, Proc. Natl. Acad. Sci. U. S. A., 97, 9875-9880, 2000.

Holben, B. N., Eck, T. F., Slutsker, I., Tanre, D., Buis, J. P., Setzer, A., Vermote, E., Reagan, J. A., Kaufman, Y., Nakajima, T., Lavenu, F., Jankowiak, I., and Smirnov, A.: AERONET - A federated instrument network and data archive for aerosol characterization, Remote Sens. Environ., 66, 1-16, 1998.

Holben, B., Tanre, D., Smirnov, A., Eck, T., Slutsker, I., Abuhassan, N., Newcomb, W. W., Schafer, J., Chatenet, B., Lavenue, F., Kaufman, Y., Castle, J. V., Setzer, A., Markham, B., Clark, D., Frouin, R., Halthore, R., Karnieli, A., O’Neill, N., Pietras, C., Pinker, R., Voss, K., and Zibordi, G.: An emerging ground-based aerosol climatology: Aerosol Optical Depth from AERONET, J. Geophys. Res., 106, 12067-12097, 2001.

Hu, X., Zhang, Y., Zhang, G., Huang, Y., and Wang, Y.: Measurements and study of aerosol optical characteristics in China radiometric calibration site, J. Appl. Meteor. Sci., 12, 257-266, 2001 (in Chinese).

Huebert, B. J., Bates, T., Russell, P. B., Shi, G., Kim, Y. J., Kawamura, K., Carmichael, G., and Nakajima, T.: An overview of ACE-Asia: Strategies for quantifying the relationships between Asian aerosols and their climatic impacts, J. Geophys. Res., 108, 8633, doi:10.1029/2003JD003550, 2003.

IPCC: Climate Change 2007: The Scientific Basis, Cambridge University Press, New York, Forth Assessment Report, 996 p., 2007.

IPCC: Climate Change 2013: The Physical Science Basis. Contribution of Working Group I to the Fifth Assessment Report of the Intergovernmental Panel on Climate Change, edited by: Stocker, T. F., Qin, D., Plattner, G.-K., Tignor, M., Allen, S. K., Boschung, J., Nauels, A., Xia, Y., Bex, V., and Midgley, P. M., Cambridge, United Kingdom and New York, 1535 p., 2013.

Jiang, Y., Luo, Y., Zhao, Z., and Tao, S.: Changes in wind speed over China during 1956-2004, Theor. Appl. Climatol., 99, 421-430, 2010 . 
Kim, D. H., Sohn, B. J., Nakajima, T., Takamura, T., Takemura, T., Choi, B. C., and Yoon, S. C.: Aerosol optical properties over east Asia determined from ground-based sky radiation measurements, J. Geophys. Res., 109, D02209, doi:10.1029/2003JD003387, 2004.

Kim, D. H., Sohn, B. J., Nakajima, T., and Takamura, T.: Aerosol radiative forcing over east Asia determined from ground-based solar radiation measurements, J. Geophys. Res., 110, D10S22, doi:10.1029/2004JD004678, 2005.

Lei, Y., Zhang, Q., He, K. B., and Streets, D. G.: Primary anthropogenic aerosol emission trends for China, 1990-2005, Atmos. Chem. Phys., 11, 931-954, doi:10.5194/acp-11-931-2011, 2011.

Li, B., Yuan, H., Feng, N., and Tao, S.: Comparing MODIS and AERONET aerosol optical depth over China, Int. J. Remote. Sens., 30, 6519-6529, 2009.

Li, C. C., Mao, J. T., and Lau, K. H.: Characteristics of the aerosol optical depth distributions over Sichuan Basin derived from MODIS data, J. Appl. Meteor., 14, 1-7, 2003 (in Chinese).

Li, F. and Lu, D.: Optical properties of atmospheric aerosols over Mount Qomolongma, Chinese J. Atmos. Sci., 19, 755-763, 1995 (in Chinese).

Li, X., Chen, Y., Hu, X., Ren, Y., and Wei, W.: Analysis of atmospheric aerosol properties over Urumqi, China Environ. Sci., 25, 22-25, 2005 (in Chinese).

Li, Z. Q., Xia, X. G., Cribb, M., Mi, W., Holben, B., Wang, P., Chen, H. B., Tsay, S. C., Eck, T. F., Zhao, F. S., Dutton, E. G., and Dickerson, R. E.: Aerosol optical properties and their radiative effects in northern China, J. Geophys. Res., 112, D22S01, doi:10.1029/2006JD007382, 2007.

Liang, F. and Xia, X. A.: Long-term trends in solar radiation and the associated climatic factors over China for 1961-2000, Ann. Geophys., 23, 2425-2432, doi:10.5194/angeo-23-2425-2005, 2005.

Lin, J., Aaron van Donkelaarb, Xin, J., Che H., and Wang, Y.: Clearsky aerosol optical depth over East China estimated from visibility measurements and chemical transport modeling, Atmos. Environ., 95, 258-267, doi:10.1016/j.atmosenv.2014.06.044, 2014.

Liu, R., Li, L., Yu, J., Huang, W., Xu, L., Liu, M., and Tang, X.: Online measurements and characteristic analysis of aerosol optical depth in the atmosphere of Urban Chongqing, Acta Scientiae Circumstantiae, 34, 819-825, 2014 (in Chinese).

Liu, X., Yan, L., Yang, P., Yin, Z., and North, G. R.: Influence of Indian summer monsoon on aerosol loading in East Asia, J. Appl. Meteor. Climatol., 50, 523-533, doi:10.1175/2010JAMC2414.1, 2011.

Liu, Y., Niu, S., and Zheng, Y.: Optical depth characteristics of Yinchuan atmospheric aerosols based on the CE-318 sun tracking spectrophotometer data, J. Nanjing Inst. Meteor., 27, 615632, 2004 (in Chinese).

Liu, Y., Huang, J., Shi, G., Takamura, T., Khatri, P., Bi, J., Shi, J., Wang, T., Wang, X., and Zhang, B.: Aerosol optical properties and radiative effect determined from sky-radiometer over Loess Plateau of Northwest China, Atmos. Chem. Phys., 11, 1145511463, doi:10.5194/acp-11-11455-2011, 2011.

Logan, T., Xi, B., and Dong, X.: A comparison of the mineral dust absorptive properties between two Asian dust events, Atmosphere, 4, 1-16, doi:10.3390/atmos4010001, 2013a.

Logan, T., Xi, B., Dong, X., Li, Z., and Cribb, M.: Classification and investigation of Asian aerosol absorptive properties,
Atmos. Chem. Phys., 13, 2253-2265, doi:10.5194/acp-13-22532013, 2013b.

Luo, Y., Lu, D., Zhou, X., Li, W., and He, Q.: Characteristics of the spatial distribution and yearly variation of aerosol optical depth over China in last 30 years, J. Geophys. Res., 106, 14501-14513, 2001.

Mao, J., Wang, Q., and Zhao, B.: The observation of the atmospheric transparency spectrum and the turbidity, Acta Meteor. Sinica, 41, 322-331, 1983 (in Chinese).

Mei, F., Zhang, X., Lu, H., Shen, Z., and Wang, Y.: Characterization of MASDs of surface soils in north China and its influence on estimating dust emission, Chin. Sci. Bull., 49, 2169-2176, 2004.

Mi, W., Li, Z., and Xia, X., Holben, B., Levy, R., Zhao, F., Chen, H., and Cribb, M.: Evaluation of the Moderate Resolution Imaging Spectroradiometer aerosol products at two Aerosol Robotic Network stations in China, J. Geophys. Res., 112, D22S08, doi:10.1029/2007JD008474, 2007.

Pal, S. and Devara, P. C. S.: A wavelet-based spectral analysis of long-term time series of optical properties of aerosols obtained by lidar and radiometer measurements over an urban station in Western India, J. Atmos. Sol.-Terr. Phys., 84-85, 75-87, doi:10.1016/j.jastp.2012.05.014, 2012.

Pan, L., Che, H., Geng, F., Xia, X., Wang, Y., Zhu, C., Chen, M., Gao, W., and Guo, J.: Aerosol optical properties based on ground measurements over the Chinese Yangtze Delta Region, Atmos. Environ., 44, 2587-2596, 2010.

Prats, N., Cachorro, V. E., Berjón, A., Toledano, C., and De Frutos, A. M.: Column-integrated aerosol microphysical properties from AERONET Sun photometer over southwestern Spain, Atmos. Chem. Phys., 11, 12535-12547, doi:10.5194/acp-1112535-2011, 2011.

Qi, B., Du, R., Yu, Z., and Zhou, B.: Aerosol optical depth in urban site of Hangzhou, China Environ. Sci., 34, 588-595, 2014 (in Chinese).

Qin, S., Shi, G., Chen, L., Wang, B., Zhao, J., Yu, C., and Yang, S.: Long-term variation of aerosol optical depth in China based on meteorological horizontal visibility observations, Chinese J. Atmos. Sci., 34, 449-456, doi:10.3878/j.issn.10069895.2010.02.18, 2010 (in Chinese).

Qiu, J.: A method to determine atmospheric aerosol optical depth using total direct solar radiation, J. Atmos. Sci., 55, 744-757, 1998.

Qiu, J. and Yang, L.: Variation characteristics of atmospheric aerosol optical depths and visibility in North China during 1980 1994, Atmos. Environ., 34, 603-609, 2000.

Qiu, J., Wang, H., Zhou, X., and Lu, D.: Experimental study of remote sensing of atmospheric aerosol size distribution by combined solar extinction and forward scattering method, Acta Meteor. Sinica, 7, 33-41, 1983.

Qu, W., Zhang, Y., Arimoto, R., Wang, D., Wang, Y., Yan, Y., and Li, Y.: Chemical composition of the background aerosol at two sites in southwestern and northwestern China: potential influences of regional transport, Tellus B, 60, 657-673, 2008.

Quan, X., Zhang, L., Cao, X., and Wang, H.: Property of aerosol optical depth over Lanzhou city in the winter of 2007, J. Lanzhou Univ. Nat. Sci., 45, 39-44, 2009 (in Chinese).

Ramanathan, V., Crutzen, P. J., Lelieveld, J., Mitra, A. P., Althausen, D., Anderson, J., Andreae, M. O., Cantrell, W., Cass, G. R., Chung, C. E., Clarke, A. D., Coakley, J. A., Collins, W. D., 
Conant, W. C., Dulac, F., Heintzenberg, J., Heymsfield, A. J., Holben, B., Howell, S., Hudson, J., Jayaraman, A., Kiehl, J. T., Krishnamurti, T. N., Lubin, D., McFarquhar, G., Novakov, T., Ogren, J. A., Podgorny, I. A., Prather, K., Priestley, K., Prospero, J. M., Quinn, P. K., Rajeev, K., Rasch, P., Rupert, S., Sadourny, R., Satheesh, S. K., Shaw, G. E., Sheridan, P., and Valero, F. P. J.: Indian Ocean Experiment: an integrated analysis of the climate forcing and effects of the great Indo-Asian haze, J. Geophys. Res., 106, 28371-28398, 2001.

Seinfeld, J. H., Carmichael, G. R., Arimoto, R., Conant, W. C., Brechtel, F. J., Bates, T. S., Cahill, T. A., Clarke, A. D., Doherty, S. J., Flatau, P. J., Huebert, B. J., Kim, J., Markowicz, K. M., Quinn, P. K., Russell, L. M., Russell, P. B., Shimizu, A., Shinozuka, Y., Song, C. H., Tang, Y. H., Uno, I., Vogelmann, A. M., Weber, R. J., Woo, J. H., and Zhang, X. Y.: ACE-ASIA: Regional climatic and atmospheric chemical effects of Asian dust and pollution, B. Am. Meteorol. Soc., 85, 367-380, 2004.

Shao, M., Lu, S., Liu, Y., Xie, X., Chang, C., Huang, S., and Chen, Z.: Volatile organic compounds measured in summer in Beijing and their role in ground-level ozone formation, J. Geophys. Res., 114, D00G06, doi:10.1029/2008JD010863, 2009.

Smirnov, A., Holben, B. N., Eck, T. F., Dubovik, O., and Slutsker, I.: Cloud screening and quality control algorithms for the AERONET database, Remote Sens. Environ., 73, 337-349, 2000

Streets, D. G., Gupta, S., Waldhoff, S. T., Wang, M. Q., Bond, T. C., and Bo, Y.: Black carbon emissions in China, Atmos. Environ., 35, 4281-4296, 2001.

Su, X., Cao, J., Li, Z., Lin, M., and Wang, G.: Column-integrated aerosol optical properties during summer and autumn of 2012 in Xi'an, China, Aerosol Air Qual. Res., 14, 850-861, 2014.

Tan, H., Wu, D., Deng, X., Bi, X., Li, F., and Deng, T.: Observation of aerosol optical depth over the Pearl River Delta, Acta Scientiae Circumstantiae, 29, 1146-1155, 2009 (in Chinese).

Tao, J., Zhang, L., Engling, G., Zhang, R., Yang, Y., and Cao, J.: Chemical composition of $\mathrm{PM}_{2.5}$ in an urban environment in Chengdu, China:Importance of springtime dust storms and biomass burning, Atmos. Res., 122, 270-283, 2013.

Tao, R., Che, H. Z., Chen, Q. L., Wang, Y. Q., Sun, J. Y., Zhang, X. C., Lu, S., Guo, J. P., Wang, H., and Zhang, X. Y.: Development of an integrating sphere calibration method for Cimel sunphotometers in China aerosol remote sensing network, Particuology, 13, 88-99, doi:10.1016/j.partic.2013.04.009, 2014.

Uchiyama, A., Yamazaki, A., Togawa, H., and Asano, J.: Characteristics of aeolian dust observed by sky-radiometer in the Intensive Observation Period 1 (IOP1), J. Meteor. Soc. Japan, 83A, 291305,2005

Wang, D. and Qiu, J.: The study of atmospheric aerosol optical properties in Takla-Makan desert in spring, Chinese J. Atmos Sci., 12, 75-81, 1988 (in Chinese).

Wang, J., Yang, S., Zhao, Q., and Cui, S.: Analyses of aerosol properties in Hefei based on polarization measurements of a sun photometer, Int. J. Remote Sens., 33, 69-80, 2012.

Wang, P., Che, H., Zhang, X., Song, Q., Wang, Y., Zhang, Z., Dai, $\mathrm{X}$., and Yu, D.: Aerosol optical properties of regional background atmosphere in Northeast China, Atmos. Environ., 44, 4404-4412, doi:10.1016/j.atmosenv.2010.07.043, 2010.

Wang, X., Huang, J., Zhang, R., Chen, B., and Bi, J.: Surface measurements of aerosol properties over northwest China during
ARM China 2008 deployment, J. Geophys. Res., 115, D00K27, doi:10.1029/2009JD013467, 2010.

Wang, Y., Xin, J., Li, Z., Wang, S., Wang, P., Hao, W. M., Nordgren, B. L., Chen, H., Wang, L., and Sun, Y.: Seasonal variations in aerosol optical properties over China, J. Geophys. Res., 116, D18209, doi:10.1029/2010JD015376, 2011.

Wang, Z., Liu, D., Wang, Z., Wang, Y., Khatri, P., Zhou, J., Takamura, T., and Shi, G.: Seasonal characteristics of aerosol optical properties at the SKYNET Hefei site $\left(31.90^{\circ} \mathrm{N}, 117.17^{\circ} \mathrm{E}\right)$ from 2007 to 2013, J. Geophys. Res. Atmos., 119, 6128-6139, doi:10.1002/2014JD021500, 2014.

Wehrli, C.: Calibration of filter radiometers for the GAW Aerosol Optical Depth network at Jungfraujoch and Mauna Loa, Proceedings of ARJ workshop, SANW congress, Davos, Switzerland, 70-71, 2002.

Wu, Y., Zhu, J., Che, H., Xia, X., and Zhang, R.: Columnintegrated aerosol optical properties and direct radiative forcing based on sun photometer measurements at a semi-arid rural site in Northeast China, Atmos. Res., 157, 15, 56-65, doi:10.1016/j.atmosres.2015.01.021, 2015.

Xia, X.: A closer looking at dimming and brightening in China during 1961-2005, Ann. Geophys., 28, 1121-1132, doi:10.5194/angeo-28-1121-2010, 2010.

Xia, X. A., Chen, H. B., Wang, P. C., Zong, X. M., and Gouloub, P.: Aerosol Properties and Their Spatial and Temporal Variations over north China in Spring 2001, Tellus B, 57, 28-39, 2005.

Xia, X. A., Chen, H. B., Li, Z. Q., Wang, P. C., and Wang, J. K.: Significant reduction of surface solar irradiance induced by aerosols in a suburban region in northeastern China, J. Geophys. Res., 112, 1-9, 2007.

Xiao, Z., Jiang, H., Chen, J., Wang, B., and Jiang, Z.: Monitoring the aerosol optical properties over Hangzhou using remote sensing data, Acta Scientiae Circumstantiae, 31, 1758-1767, 2011 (in Chinese).

Xie, Y., Zhang, Y., Xiong, X., Qu, J. J., and Che, H.: Validation of MODIS aerosol optical depth product over China Using CARSNET Measurements, Atmos. Environ., 45, 5970-5978, 2011.

Xin, J., Wang, Y., Li, Z., Wang, P., Hao, W., Nordgren, B., Wang, S., Liu, G., Wang, L., Wen, T., Sun, Y., and Hu, B.: Aerosol optical depth (AOD) and Ångström exponent of aerosols observed by the Chinese Sun Hazemeter Network from August 2004 to September 2005, J. Geophys. Res., 112, D05203, doi:10.1029/2006JD007075, 2007.

Xue, Y., Xu, H., Guang, J., Mei, L., Guo, J., Li, C., Mikusauskas, R., and He, X.: Observation of an agricultural biomass burning in central and east China using merged aerosol optical depth data from multiple satellite missions, Int. J. Remote. Sens., 35, 59715983, doi:10.1080/2150704X.2014.943321, 2014.

Yoon, S., Kim, S., Choi, S., and Choi, I.: Regional-scale relationships between aerosol and summer monsoon circulation, and precipitation over Northeast Asia, Asia-Pacific J. Atmos. Sci., 46, 279-286, 2010.

Yu, X., Zhu, B., Yin, Y., Fan, S., and Chen, A.: Seasonal variation of columnar aerosol optical properties in Yangtze River Delta in China, Adv. Atmos. Sci., 28, 1326-1335, 2011.

Zha, S. P., Zhang, S. Q., Cheng, T. T., Chen, J. M., Huang, G. H., Li, X., and Wang, Q. F.: Agricultural fires and their potential impacts 
on regional air quality over China, Aerosol Air Qual. Res., 13, 992-1001, 2013.

Zhang, J., Mao, J., and Wang, M.: Analysis of aerosol extinction characteristics in different areas of China, Adv. Atmos. Sci, 19, 136-152, 2002.

Zhang, J., Chen, J., Xia, X., Che, H., Fan, X., Xie, Y., Chen, H., and Lu, D.: Heavy aerosol loading over the Bohai Bay as revealed by ground and satellite remote sensing, Atmos. Environ., in press, doi:10.1016/j.atmosenv.2015.03.048, 2015.

Zhang, R., Jing, J., Tao, J., Hsu, S.-C., Wang, G., Cao, J., Lee, C. S. L., Zhu, L., Chen, Z., Zhao, Y., and Shen, Z.: Chemical characterization and source apportionment of $\mathrm{PM}_{2.5}$ in Beijing: seasonal perspective, Atmos. Chem. Phys., 13, 7053-7074, doi:10.5194/acp-13-7053-2013, 2013.

Zhang, X. Y., Gong, S. L., Zhao, T. L., Arimoto, R., Wang, Y. Q., and Zhou, Z. J.: Sources of Asian dust and role of climate change versus desertification in Asian dust emission, Geophys. Res. Lett., 30, 2272, doi:10.1029/2003GL018206, 2003.

Zhang, X. Y., Wang, Y. Q., Niu, T., Zhang, X. C., Gong, S. L., Zhang, Y. M., and Sun, J. Y.: Atmospheric aerosol compositions in China: spatial/temporal variability, chemical signature, regional haze distribution and comparisons with global aerosols, Atmos. Chem. Phys., 12, 779-799, doi:10.5194/acp12-779-2012, 2012.

Zhao, B., Wang, Q., Mao, J., and Qin, Y.: Study on remote sensing of aerosol optical depth and vapor, Sci. China (Ser. B), 10, 951962, 1983 (in Chinese).
Zhao, H., Che, H., Zhang, X., Ma, Y., Wang, Y., Wang, X., Liu, C., Hou, B., and Che, H.: Aerosol optical properties over urban and industrial region of Northeast China by using ground-based sunphotometer measurement, Atmos. Environ., 75, 270-278, 2013.

Zhou, C., Gong, S., Zhang, X., Liu, H., Xue, M., Cao, G., An, X., Che, H., Zhang, Y., and Niu, T.: Towards the improvements of simulating the chemical and optical properties of Chinese aerosols using an online coupled model CUACE/Aero, Tellus B, 64, 18965, doi:10.3402/tellusb.v64i0.18965, 2012.

Zhu, J., Liao, H., and Li, J.: Increases in aerosol concentrations over eastern China due to the decadal-scale weakening of the East Asian summer monsoon, Geophys. Res. Lett., 39, L09809, doi:10.1029/2012GL051428, 2012.

Zhu, J., Che, H., Xia, X., Chen, H., Goloub, P., and Zhang, W.: Column-integrated aerosol optical and physical properties at a regional background atmosphere in North China Plain, Atmos. Environ., 84, 54-64, doi:10.1016/j.atmosenv.2013.11.019, 2014.

Zhuang, B. L., Jiang, F., Wang, T. J., Li, S., and Zhu, B.: Investigation on the direct radiative effect of fossil fuel black-carbon aerosol over China, Theor. Appl. Climatol., 104, 301-312, 2011.

Zhuang, B. L., Wang, T. J., Li, S., Liu, J., Talbot, R., Mao, H. T., Yang, X. Q., Fu, C. B., Yin, C. Q., Zhu, J. L., Che, H. Z., and Zhang, X. Y.: Optical properties and radiative forcing of urban aerosols in Nanjing, China, Atmos. Environ., 83, 43-52, doi:10.1016/j.atmosenv.2013.10.052, 2014. 